\title{
EVERSLEY \\ GARDENS \\ AND OTHERS
}

ROSE G. BHNChITy

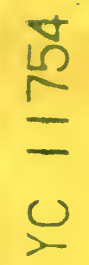




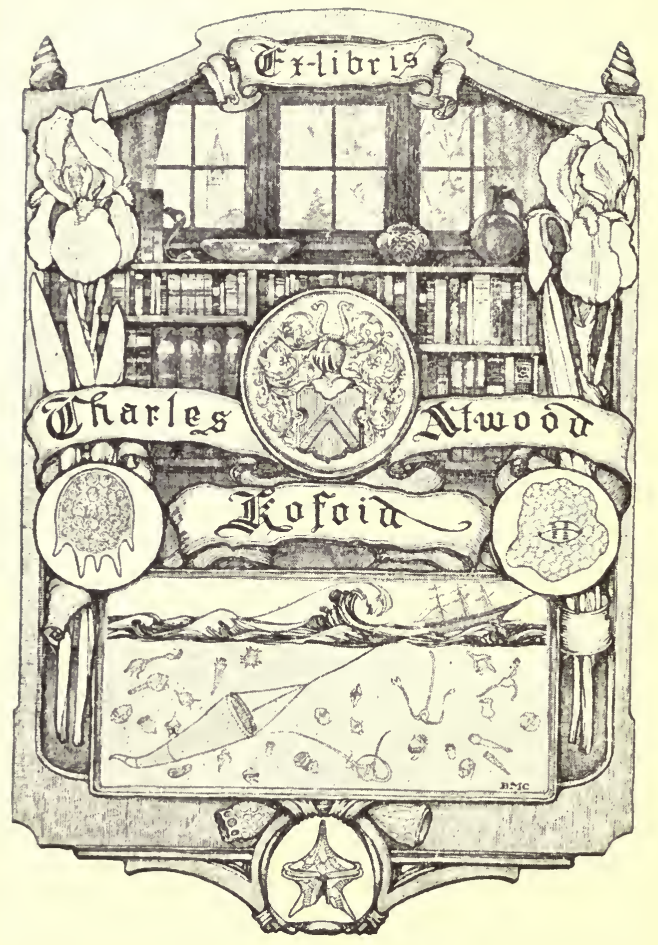




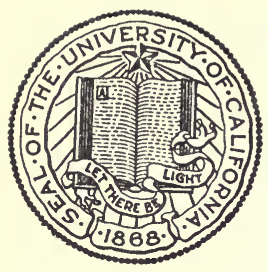

\title{
THE LIBRARY
}

OF

THE UNIVERSITY

OF CALIFORNIA

\author{
PRESENTED BY
}

PROF. CHARLES A. KOFOID AND

MRS. PRUDENCE W. KOFOID 



\section{EVERSLEY GARDENS}

AND OTHERS 




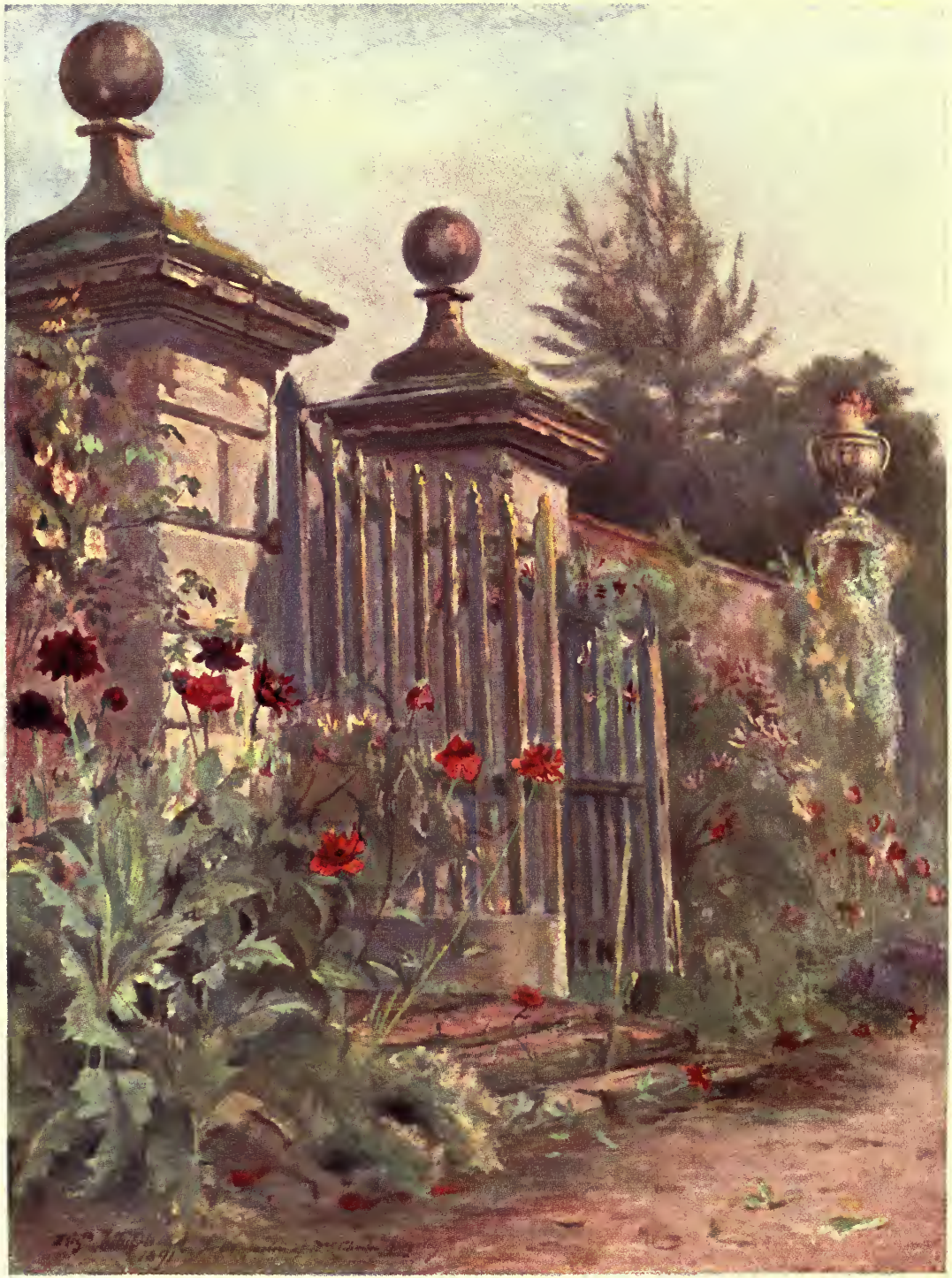

THE GARDEN GATE.

TACHBROOK MALLORY. 


\title{
EVERSLEY GARDENS
}

\section{AND OTHERS}

\author{
BY \\ ROSE G. KINGSLEY \\ OFFICIER DE L'INSTRUCTION PUBLIQUE \\ AUTHOR OF "SOUTH BY WEST," "CHILDRHN OF WESTMINSTER ABBEY
}

"A HISTORY OF FRENCH ART"

WITH 18 ILLUSTRATIONS

NEW YORK

THE MACMILLAN COMPANY

LONDON : GEORGE ALLEN 



\section{NOTE}

Some of the garden notes on which much of this little book is founded having appeared during the last four years in the Guardian and the Daily Telegraph, I desire to acknowledge the courtesy of the Editors of those papers with regard to their incorporation in these pages.

My warm thanks are also due to Lt.-Colonel Sir Anthony Cope for his permission to use the photographs of Bramshill; and to Sir William Farrer for those of his famous garden; to Miss Margaret Waterfield for the use of her beautiful drawing of the Blue Lilies; and to my friend Mrs. Emmons for allowing the reproduction of Miss Whitehead's picture, now in her possession, of the gate at Tachbrook Mallory.

ROSE G. KINGSLEY.

Keys, EversLey, May 7, 1907. 



\section{O N TEN TS}

CHAP.

PAGE

I. Making the Garden . . . . I I

II. Concerning Solls, Plantings, AND

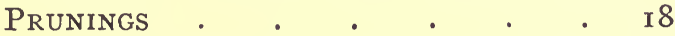

III. The Spring Garden and its BulbS • 40 IV. May Garlands . . . . . . 60

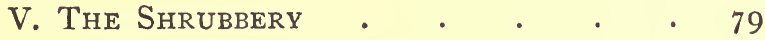

VI. The Summer Garden . . . . Ior VII. The Rose Garden . . . . . I 25 VIII. The Rose Garden (continued) • . 149

IX. A Garden of Delight . . . . 173

X. Cut Flowers, and a Few Hints on Their Arrangement . . . . . $\quad$ i 88

XI. Birds and Gardens . . . . 203

XII. The Autumn Garden . . . . 220

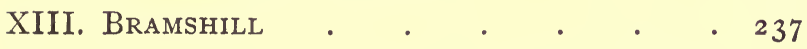
XIV. The Rectory Garden and The Mount 254 INDEX $\underset{\mathrm{ix}}{\cdot} \quad \cdot b^{277}$ 



\section{LIST OF ILLUSTRATIONS}

Garden Gate, Tachbrook Mallory. (By Miss Whitehead.) (Colour).

Frontispiece

Keys, From the Garden . . To face page 2

The Blackwater . . . . . " , 24

Daffodils and Double Peach • " 46

The Broad Walk (Spring) . . " , 66

Daffodils in the Wild Garden . " " 68

Prunus Pissardil . . . . . .

FORTUNE'S Yellow . . . . . " " I5O

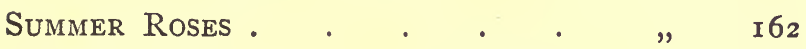

Nympнжа Scutifolia. (By Miss $\}$,, I73

Margaret Waterfield.) (Colour) $\} \quad$ I73

The Broad Walk (Summer) . . " "

A Lily Pond . . . . . . . $\quad$, $\quad$ I78

Pink Hydrangeas . . . . " , 180

Hydrangea Paniculata and Lobelia , 230

Bramshill (South-West) . . . " , 240

Bramshill (South-East) . . . " " 242

Japanese Honeysuckle • . . $\quad, \quad 258$

The Study Garden, $186_{5 \mathrm{i}}$. • , " $\quad 270$ 



\section{EVERSLEY GARDENS}

\section{CHAPTER I}

MAKING THE GARDEN

IT was a pink Wild-rose in a gap that decided my fate eight years ago, as I stepped into the bare little meadow. On three sides, east, south, and west, were rough hedges of Furze, Broom, Wild-rose, Bramble, and Hawthorn. On the north ran an old bank, the ancient boundary of cultivated land, with noble Hollies, Crabs, and wild Apple trees, a fine Elder, a big Hawthorn, a promising Oak, and countless Briar-roses. Fifty years ago it was a bit of common on which geese and donkeys fed, and made a maze of little pathways among the Furze bushes of fine moorland turf, where the Camomiles gave forth their pungent scent 


\section{EVERSLEY GARDENS}

as the foot crushed them, and the boys, now well-to-do fathers of families, staid Churchwardens and Parish Councillors, hunted for stone-chats' nests. The meadow, an acre and a quarter, sloped gently from the high-road on the south to the west and north with a fall of some twelve feet. This was my land of promise; and here I decided to build a shelter for my old age.

Of course neighbours and friends were lavish in advice, in discouragement, in warnings, even in disapprobation. But as the only human being to whose judgment I absolutely defer-knowing it to be sound, wise, and farseeing-gave me her approbation; and as, indeed, I had no one to please but myself, I bought the land, with two more charming old meadows behind the Holly hedge that run down to the little river dividing Hampshire from Berkshire, eight acres in all. It was an ancient holding, known as Keys; and a sore puzzle has that name been to all and sundry. Some direct to me at "The Keys," which only suggests a low public-house or gin-palace. 


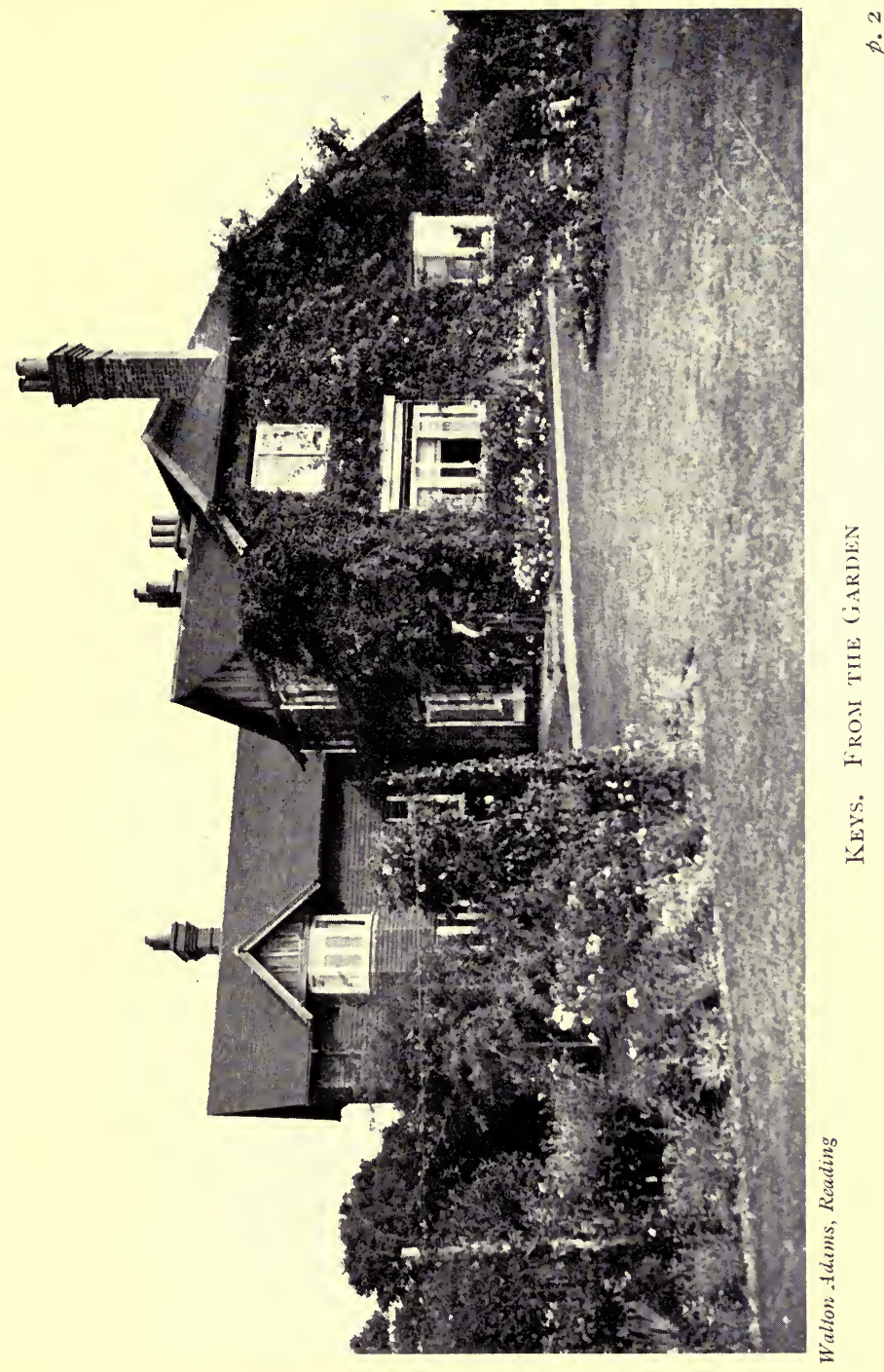



Others will spell it "Keyes," imagining it to be called after some distinguished person. And none guess its purely local origin; coming from the seed-pods or, as we here in North Hampshire call them, "keys" of the Ash-a group of huge old Ash trees, long since dead, having stood in the lower meadow near the river.

The dear, good neighbours! After their first objections with regard to my insane project of buying the land and building at all, they simply inundated me with advice as to what I should do. They did not even preface this with "If I were you :" but made positive assertions. I counted seven different positions in my one and quarter acre meadow on which I was told that I ought to build my house. Six of these commands I bore with patience which might, I think, have been counted to me for righteousness, if I had not mislaid my temper at the seventh. For when my would-be guide, philosopher, and friend insisted that the house ought to be placed in the very lowest corner of the whole 


\section{4 EVERSLEY GARDENS}

land, where I knew there was a little streak of clay and no fall for drainage, instead of on the fine dry sand and gravel where it now stands, I fear I intimated that no doubt he was right; but that, as I was building the house for myself and not for him, I preferred to choose the site. After that I had no more advice.

As I brushed against that pink Wild-rose in the gap, I saw in a flash there were possibilities in the bare little meadow. On the north side of the rough-very rough-hedge of Bramble, Furze and Broom, with here a strong Briar-rose, there a bit of straggling quickset, with many a gap besides, lying between my land of promise and the high-road from Reading to Aldershot, it was evident that there must be a long straight border, with Rhododendrons planted close to the bank, so that in course of time they might form a solid screen from the road. That was the one definite thing that had to be done first of all. But before going further, I thought it might be well to take counsel as to how to lay out the garden 


\section{MAKING THE GARDEN}

with the wisest and best of all authorities, my master in garden craft and honoured friend, the late G. F. Wilson, F.R.S., of Weybridge. By return of post I received a characteristic answer, "If you want to enjoy your garden, take nobody's advice, and lay it out exactly according to your own fancy." This set me free. I have closely adhered to this wise counsel; and thereby, if I have annoyed some of my over-wise neighbours, I have certainly, in spite of mistakes, given myself a great deal of pleasure.

I confess to a passion for straight lines; and in the gradual growth of the garden that passion has found scope and gratification. There is only one curved corner in the whole place; and that was a necessity, to enable me to work in a straight walk with the outer hedge on the west, which is as much out of the parallel with the rest of the garden as Visconti found the Rue de Rivoli with the Louvre of Henry IV. One round Rose bed was cut out in the Rose garden last year-to be followed in course of time by two others in 


\section{EVERSLEY GARDENS}

the same line-containing a number of Rose bushes too large for the five-foot straight borders. Otherwise straight lines and right angles, as near as may be, are the order of the day.

First of all, then, the long border under the hedge had to be made-and in fact it was begun before ever a brick of the house was laid-ten feet wide from the hedge and trenched three spits deep. I collected an admirable supply of soil for it; for it needed "making" all the way. While wandering round the parish, through woods and bogs, meadows and lanes, I made one of my most lucky hits in soil. Under the hedge of one of the poor "Starve-donkey" fields that creep up into the great heather moors of Hartfordbridge Flats, I saw lying beside the road a heap of rotten turfs. They were the real old-fashioned round turfs with the Heather left on them, which were universally used here for fuel forty to fifty years ago, and were, alas! so fruitful a cause of terrible burns in the cottages, until my mother supplied 
fireguards wherever there were young children. The poor babies would draw round what seemed to be a dead fire on the hearth, and hold up their little "pinnas" or their frocks to dry, when a turf would crack, fall and blaze up, as would the poor mites' clothes. Never shall I forget some of the burns I saw in my childhood from this cause. My turfs were innocent of such possibilities; for the farmer had cut them from the moor close by to cover his big potato heap; and now the potatoes were sold, and the turfs well-rotted and useless to him. I fell upon them as on lost treasure, found them in perfect condition, and got a neighbour to bargain for twenty loads at a small price and draw them in for me. Dug in with good manure where it was needed, brown fibrous turfy loam, of which more anon, and road-scrapings from Brick House Hill full of fallen oak leaves from the Mount, they made that long border one of the best I have ever had. And in it Rhododenrons, Azaleas, Japanese Roses, Penzance Sweetbriars, and every sort of odd and end, 
from rich and poor, cottage and palace, have grown and flourished-nay, in some cases have run riot-a medley of colour and fragrance that is a joy throughout the year, against the tall Furze and Broom, Bramble and Hawthorn.

Rose beds came next, as the walls of the house began to rise in March, and show me where I stood; one on the north and one on the west, about twenty feet from the house. The north bed contained a good mixed collection of Hybrid Perpetuals from my old friend Mr. Alfred Perkins of Coventry; and for the first years they made a brave show from the French windows of the dining-room. But I had an object-lesson twelve months ago, as to the importance of seeing that the actual trenching of a new Rose bed is carried out under one's own eye. Three years ago they did less well. Next year they did badly, and I was put to shame, and wondered how and why, and decided to move the whole lot and plant a shelter of choice Rhododendrons in 
their place, as I thought the wind had spoilt them. They were lifted and put into newlyprepared beds; and I told my then gardener in an airy manner just to fork over the old bed and put in the Rhododendrons, as the soil was sure to be good. He began, and came to me in dismay and disgust. The old Rose bed had never been trenched at all. The hard sandy marl and gravel began about eighteen inches below the surface, and the only wonder was that the wretched Roses had grown at all. I had given the orders seven years and more ago, and trusted to their being carried out implicitly in my absence. Alas, for a trustful belief in the integrity of undirected human nature! We took five loads of solid marl and gravel out of that wretched bed, and had, of course, to replace them with seven or eight of fibrous turf, leaf-mould, and manure; while the poor starved Roses, rejoicing in their new quarters, have taken a new lease of life, and repaid me with glorious flowers and healthy shoots. 
The west bed, opposite the other window, has been an even greater and more lasting joy. Late in April, I thrust into it, with but little hope of their ultimate survival, twenty dwarf Roses, mainly Magna Chartathe one really successful bargain of my life. A gardening friend, knowing that at the start I should think more of quantity than quality in filling the bare garden, told me that some hundreds of foreign Roses had been offered to him, left over from the last plant sales of the season at the auction rooms of a neighbouring town, and that he believed any bid would be taken. I offered 5s. for 100; and got them for 6s. 6d. Some I gave away; the rest I kept. Few things in the garden have given me more satisfaction than the great bushes laden with masses of huge rose-pink blossoms, upon which I look at every meal in the Summer. And I have a shrewd suspicion that they are on their own roots; for never a sign have they shown of the vile suckers which destroy half the budded dwarfs; so that I trust they may last as long as I have 
eyes to look on them, and a heart to rejoice in their beauty.

A tall Rose fence came next along the east, of old-fashioned Climbing Roses I remembered as a child at the Rectory-Dundee Rambler, Williams' Evergreen, Félicité Perpétuée, Princess of Nassau, Rivers' Musk, Beauté des Prairies, Céline Forestier, Setina, Maria Leonida, Gloire des Rosomanes, and the more modern Carmine Pillar, Alister Stella Gray, Euphrosyne, \&c.

Then came the orchard, sheltered by the northern hedge. I had dreamt of that orchard almost as soon as I decided to buy and build. Three rows of Apples, Pears, Plums, and Cherries, were planted diagonally, so that their blossoms should blend eighteen feet apart, thus-

$\begin{array}{cccc}\text { Cherry. } & \text { Pear. } & \text { Plum. } & \text { Apple. } \\ , " & , " & , " & , " \\ , " & ", & , "\end{array}$

My selection was as follows. And when I made nearly the same for another orchard last year, and sent it for approval to Messrs. 
William Paul \& Sons from whom the trees were to come, I received the gratifying answer that they thought it needed no alteration.

Apples. - Bramley's Seedling. Dumelow's Seedling. Golden Winter Pearmain. Warner's King. Kentish Fillbasket. Devonshire Quarenden. Keswick Codlin. Worcester Pearmain. Celine Pippin. Echlinville Seedling. Blenheim Orange.

Pears.-Beurré d'Amanlis. Fargonelle. Pitmaston Duchesse d'Angoulême. Fertility. Catillac. One or two have been added since, such as Williams' Bon Chrétien.

Plums and Damsons. - Early Prolific. Angelina Burdett. Chester Damson. Smith's early Prolific. The Czar. Farleigh's Prolific. Victoria. Pond's Seedling. Pershore Egg. Prune Damson.

Cherries. - These are generally a failure in this district-though curiously enough the Wild Cherry grows superbly in every wood and hedgerow-and mine, alas! have been no exception. Only a few survive, and these are feeble. Among those planted were 


\section{MAKING THE GARDEN}

Whiteheart, Morello, May Duke, Elton, Bigarreau Napoleon, Governor Wood.

My first idea was to grow the trees in the grass. But four years ago, as they seemed to need a little help, I trenched the ground about them, planting potatoes to clean it, and intended to sow it again in grass. It proved, however, so valuable an adjunct to the kitchen garden, and the trees benefited so much by well-worked soil, that it stays in cultivation-the homely cabbage and fragrant onion being screened from the house by a thick line of tall Autumn perennials, Sweet-peas, and Dahlias.

Tree-planting came about the same time, some of it even before the house was built. Down the long straight walk, under the western hedge, a line of Limes were put in for shade and shelter, and have grown so vigorously that each alternate one has been moved to the other side of the walk along the edge of the croquet ground, making a charming little avenue. Hard by, in the rough grass, a group of three Horse Chestnuts, two Balsam Poplars, a Scarlet Oak, and three Sycamores, 
known as the Bosquet de Fulie, breaks the western slope, and now gives pleasant shade to the southern end of the croquet ground. Tall trees, Chestnuts, Norway and Scarlet Maples, Ash, Laburnum, Acacia, and Sycamore, with a grand Hornbeam from Elvetham Park, were planted behind the Limes against the west hedge. And a tall spire of Lombardy Poplar, contrasting finely with its background of big hollies in the north-west corner, proved so irresistible to Puschkin and Gogol, the kittens, that they scored its young bark to such an extent as to make me fear for its life. Puschkin, alas! noble and loving cat, a furry monster I brought over five miles, yelling and scratching in a fish bag when a mere ball of long hair, went the way of all best cats, by the wickedness of keepers. But his smug and wary sister, Gogol, though she tempts her innumerable kittens across the road, and into the danger zone towards Eversley Wood, has so far managed to save her skin, and her surviving descendants have peopled the homes of friends far and near. For rapid effect nothing can beat the Poplar; 
and I have found that the black almost outstrips the delightful balsam. But though the Balsam gives but sparse shade, how delicious it is in colour, scent, and sound. The huge Balsam Poplars in the glebe field at the Rectory were the delight of our childhood, with their red catkins in Spring, and their gently rustling leaves overhead in May-time, when we made our big nest under the huge one close to the gate-much to dear old George Chaplin's annoyance, as he said we wasted such a lot of good hay " amucking it about." But no garden, no park, can be perfectly satisfactory to my mind without the lofty, tapering spire of a Lombardy. Even in Winter the upward growth of its slender branches makes it a delightful object, pale yellow against the blue distance or the dark foliage of Hollies; and when in Spring its leaf buds open, its beauty is unsurpassable. What that beauty could be, I never fully realised until one early June day at Aix-lesBains as I looked southward along the valley, and a dozen great Poplars caught the sun and 
turned into pillars of quivering gold-dust against the blue mountain wall towards the Grande Chartreuse. It was a vision of wonder that has never faded in nigh upon thirty long years; and though I loved Lombardy Poplars from my childhood, since that moment they have been invested with a sense of mysterious beauty that makes one understand why primitive man worshipped trees as well as serpents.

Thus, on these beginnings, humble and simple as they seem, the garden has grown, and still is growing; for why should it ever be finished? Here a bush, and there a treemany of them gifts from old friends and new -have been planted where they will add to effect or shelter. At first it seemed so strange to think that I could do exactly what I liked with my own, that at times one was stricken with a queer sense of paralysis of will and energy, a sort of counterpart of the Puritan conscience that torments itself and stultifies action in foolish questionings as to whether such and such a perfectly innocent thing is right or wrong. Then gradually one awoke to the 
surprising truth that there was neither moral right nor moral wrong to be considered in this case - that if one did not like the position of a tree or the line of a new border, it could be moved to another spot or turfed over. What an emancipation! How one's imagination began to gallop; so that one was impatient for the dawn to come, in order to gaze out of the window and plan new conquests and new adventures suggested in the still darkness. To the hitherto landless, how intoxicating is the possession of land. And as a very humble follower of "the valiant woman" who " hath seen a field and bought it and planted a vineyard," one may lay aside vain and foolish, because baseless, fears and questioning, and go forward in hope and confidence. 


\section{EVERSLEY GARDENS}

soil and soils, when the Lime trees turn yellow and warn us to make ready for next year. For they are the first to go, after giving us months of delight; smooth red twigs, plump crimson buds, delicate, almost translucent young green leaves, and that enchanting, subtle sweetness of pale, yellow-green flowers beloved of bees that conjures up all manner of lovely and penetrating memories. Florence at Midsummer, when every bush in the Boboli gardens has its nightingale, and great moths hawk round the globes of electric light that turn the cornice of the Campanile into a ledge of Alpine snow against the blue-black of the starlit sky. Or the avenue of some stately Jacobean house, such as Bramshill, when the goatsuckers chirr-r in the July gloaming across the tufts of purple heather, and great stag-beetles boom away bolt upright to the Oak trees, and a fox barks down in the Warren. So, with such moving Midsummer-Nights' dreams in mind, I watch my young Lime trees shed their yellow and brown leaves, where I planted them eight years ago 
SOILS, PLANTINGS, PRUNINGS $2 \mathrm{I}$

with a finely altruistic sense for futurity against the western hedge. And we begin to fork the earth round their roots and round the orchard trees, and feed them with "good stuff," in garden parlance, of loam and the excellent and heterogeneous mixture from the rubbish heap and marrow bed behind the stable.

That marrow bed-at least the first of several-was a very object-lesson in garden economy. Its third or fourth successor is being constructed on the same lines as I write. Its shell was made of rough grass turfs, the top spit taken from the bit of meadow I turned into a kitchen garden; and how generously has that bit repaid me with its Custard Marrows, and Strawberries, and melting joys of green Peas, and real French haricots-verts straight from Paris; for no English "butter beans," however good, can compare with the "noir hâtif de Belgique" I get over every year from MM. Vilmorin Andrieux et Cie. The turfs gradually rotted down in sun and rain into a delicious condition-I speak as a 


\section{EVERSLEY GARDENS}

soil and soils, when the Lime trees turn yellow and warn us to make ready for next year. For they are the first to go, after giving us months of delight; smooth red twigs, plump crimson buds, delicate, almost translucent young green leaves, and that enchanting, subtle sweetness of pale, yellow-green flowers beloved of bees that conjures up all manner of lovely and penetrating memories. Florence at Midsummer, when every bush in the Boboli gardens has its nightingale, and great moths hawk round the globes of electric light that turn the cornice of the Campanile into a ledge of Alpine snow against the blue-black of the starlit sky. Or the avenue of some stately Jacobean house, such as Bramshill, when the goatsuckers chirr-r in the July gloaming across the tufts of purple heather, and great stag-beetles boom away bolt upright to the Oak trees, and a fox barks down in the Warren. So, with such moving Midsummer-Nights' dreams in mind, I watch my young Lime trees shed their yellow and brown leaves, where I planted them eight years ago 
with a finely altruistic sense for futurity against the western hedge. And we begin to fork the earth round their roots and round the orchard trees, and feed them with "good stuff," in garden parlance, of loam and the excellent and heterogeneous mixture from the rubbish heap and marrow bed behind the stable.

That marrow bed-at least the first of several-was a very object-lesson in garden economy. Its third or fourth successor is being constructed on the same lines as I write. Its shell was made of rough grass turfs, the top spit taken from the bit of meadow I turned into a kitchen garden; and how generously has that bit repaid me with its Custard Marrows, and Strawberries, and melting joys of green Peas, and real French haricots-verts straight from Paris; for no English " butter beans," however good, can compare with the "noir hâtif de Belgique" I get over every year from MM. Vilmorin Andrieux et Cie. The turfs gradually rotted down in sun and rain into a delicious condition - I speak as a 
gardener, not as an ordinary human beingof crumbling soil that breaks in the hand like the shortest of pie-crust, giving promise of all manner of lovely return next Summer in blossom and growth. And the turf walls were filled with stable litter, with fine cuttings from the mowing machine off the croquet ground, with rotten marrows and potatoes that the pigs despised, and odds and ends of all sorts, which, heaped up together with burnings from the rubbish heap, made the marrows run riot the next Summer. A garden is such a blessed "glory hole," as our Irish relations call the cupboard into which they stuff all their rubbish. Nothing save actual stones (and even they are useful in paths) comes amiss to it; for, saving and excepting the said stones, everything can be burnt and used again, to lighten heavy soil, and sweeten that which otherwise might be sour.

Why will not people remember that plants, like human creatures, or dogs and cats, need food suited to their various constitutions? Yet a large proportion of garden owners seem 


\section{SOILS, PLANTINGS, PRUNINGS 23}

to think that if you put a plant-no matter what-into a border, no matter how, or where, or when-it is bound to grow, and that it is somebody's or something's fault if it does not. So it is, most assuredly. But the fault does not lie at the door generally assigned to it. For half the failures in gardens which are attributed to mice, birds, damp, frost, drought, nurserymen, and what not, are simply due to the ignorance, carelessness, or parsimony of the owner, who will not take the trouble, or incur the expense, or learn the lesson, of how to enrich or how to lighten the soil of his garden, in order to suit the requirements of this or that plant.

And the land itself needs food. I came across a deeply impressive sentence one day in a Russian novel, horrible in its poignant truth, where the little daughter of some ruined landowner overhears the cry of one of her father's labourers: "How can we work when we are hungry, when the oxen are hungry, when the land is not fed." And in terror the child perceives that their land itself must 
perish; that it is hungry like the oxen, and like them it must die. And when all land, rich or poor, needs food, as do the plants, how much more then does the light land of the north of Hampshire need suitable nourishment.

It was said by a wise and great man that, when the Almighty made the world, all the rubbish was shot in the parish of Eversley, so strangely varied is its soil. Eversley gardeners, therefore, have something to contend with; but we have also cause for gratitude in this amazing variety, if we know how to use it. Lying on the Bagshot Sands above and the Bracklesham Beds below, we get golden gravel and sand; flints, glacier and water worn, that grow again in a night after every one, great and small, has been carefully picked off a border; sour, marshy land down in the valley, with a streak of clay here and there, and cold, sandy marl; deep leaf-mould in little patches of primæval forest of Oak and Holly, "hanging upon the skirts of the moor," to paraphrase Rosalind, "like fringe upon a 


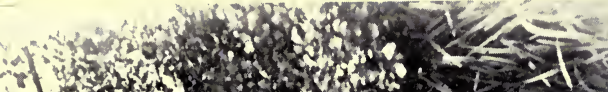

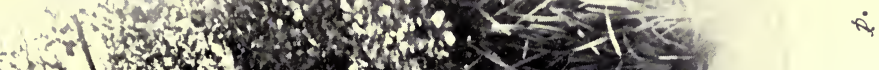

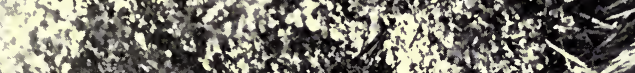

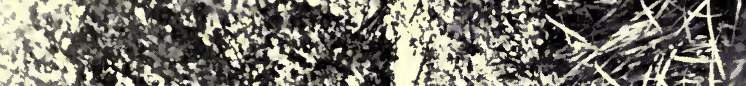

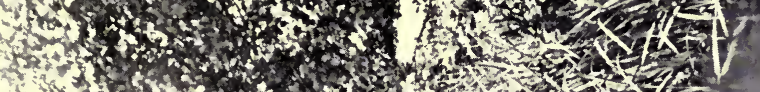

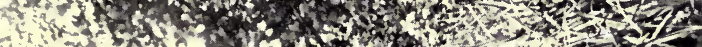

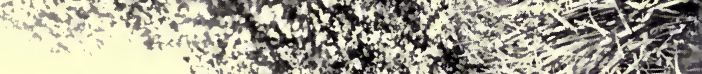

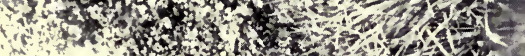

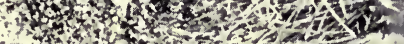

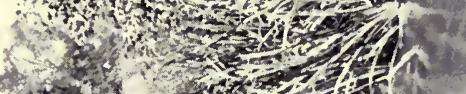

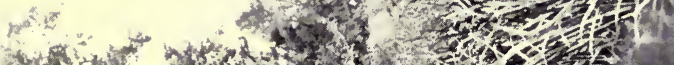

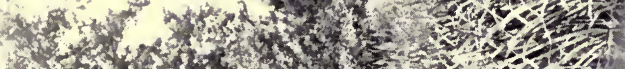

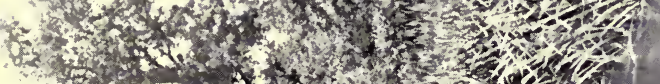

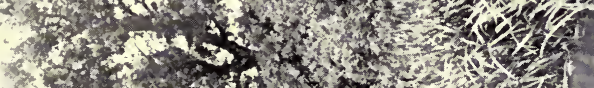

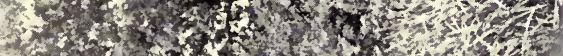

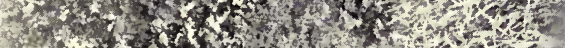

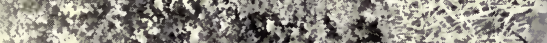

(3)

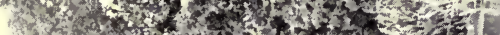

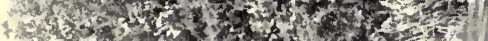

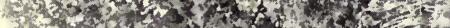

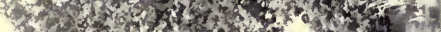

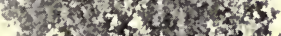

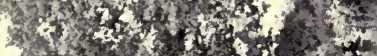

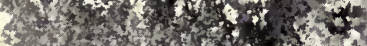

$7,42 x$ t

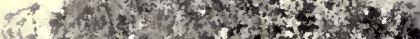

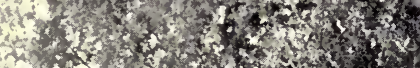

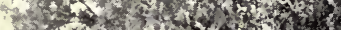

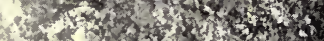

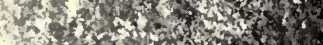

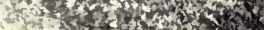

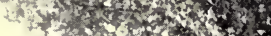

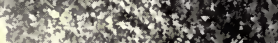

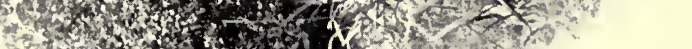

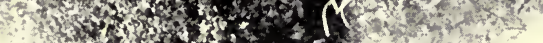

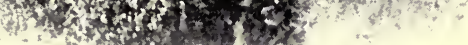
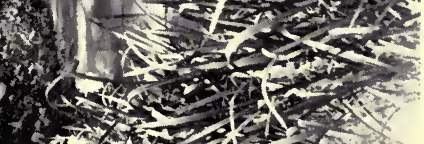

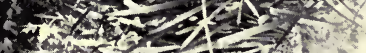

$\frac{5}{3}$ 

SOILS, PLANTINGS, PRUNINGS 25

petticoat;" for the forest of Eversley in mediæval times was the link that joined the forests of Windsor on the north-east and Pamber on the west. There is deep peat in the bogs that run up into the heatherclad stretches of Hartford-bridge Flats and the fir forests of Bramshill and Elvetham, where slow moorland streams ooze out of the iron-pan cap of the Upper Bagshots, dyed madder-brown with stems of Heather and the sponge of Sphagnum through which they creep; while in the lowland pastures along the little river Blackwater that divides Hampshire from Berkshire, we find the delicious brown fibrous turfy loam that grows the finest of Roses for those who know its precious secret.

It will easily be seen that the dear "Rubbish heap of the Universe" is poor soil and light soil. Cold draughts from the moors above bring us late and early frosts-my Dahlias have been nipped in the third week in September, while those at Bramshill Park and Finchampstead, a hundred feet higher up, have been 
untouched. We do not possess the climate of Bournemouth, or the earth of South Devon -detritus of Red Sandstone, and rich red loam, in which anything short of Coco Palms or Mangosteens will grow. But life's battles sometimes bring triumph of hard-won victory. And with care and thought, a little knowledge, and a great love, we can make our flowers grow and flourish with the best. Believing with the wise Yankee that "it takes all sorts to make a world," the philosophic gardener knows that it takes all sorts to make a garden; and that even in the "Rubbish heap" we are sure, with a little time and trouble, to find what we need for our flowers and fruit, shrubs and trees. So, when Autumn is upon us, we must prepare for it, as the marrow bed and cucumber frame will by no means suffice for our needs. We therefore lay in a load or two of real peat from a certain hollow in Bramshill Park for the Rhododendrons-no manure for them, I earnestly pray; a few more of finest old leaf-mould from under the oaks and beeches on the Mount; some good road-scrapings 


\section{SOILS, PLANTINGS, PRUNINGS 27}

with plenty of dead leaves in them, which I noted as I drove along a shady lane last week, for all road-scrapings are not alike; at least half-a-dozen loads of the precious brown fibrous loam from my lower meadow by the river; and one of good cow manure from a farmer's straw-yard, to supplement the heap from my stable, as it is far better and cooler for roses than any other. And with such a supply of "stuff" to suit all that garden and orchard contain, we may face Autumn planting, Winter frosts, and Spring renovating, with a tranquil mind and good hopes for next Summer.

If many of the failures in gardens are due to want of nourishment and proper food, how many more are owing to bad planting. I am amazed to see how lightly this all-important process is undertaken sometimes; for the successful planting of a tree, or a shrub, or a Roseespecially a Rose-does not mainly depend on digging a hole, sticking the plant in, and replacing the soil. The bed in which we intend to plant must be properly prepared. The hole 
must be properly made. The plant must be properly set in its place, and the soil properly replaced.

In good rich garden soil that has been well cultivated, eighteen inches to two feet is sufficiently deep to dig it. But in a new garden such as my own, where we come to sandy marl as a subsoil, very much more care is required to obtain good results. For Roses the beds are trenched three spits deep; the sandy marl at the bottom broken up with the fork, and two parts of brown fibrous loam and one part of good rotten manure incorporated with the surface soil. What remains, if there is nothing else handy, is then carted down the meadows and put in the shallow hole from which nine inches of the fibrous loam have been taken, and the turf which has been peeled off is then replaced, so that the hay crop of next June does not suffer. For shrubs, of course, so much of the loam is not needed. For herbaceous borders, leaf-mould and sharp gritty road-scrapings are added. For Rhododendrons all manure is excluded, loam, leaf-mould, peat, and road grit 


\section{SOILS，PLANTINGS，PRUNINGS 29}

composing the soil. When a new bed is made, it must be allowed to settle for at least a fortnight (a month is preferable), before any attempt is made to plant it ; and if rain, snow, or frost should come while it is settling, so much the better. When all is ready, and the holes made nine to twelve inches deep and eighteen inches across in a new rose bed, we have to examine our plant, cut off any bruised or torn root, as it will rot if left untrimmed, and holding the Rose in the centre of the hole with one hand, carefully spread out the roots in all directions with the other, so that they lie flat without any bending or twisting. The collar or point at which the Rose has been budded on to the stock, must be three inches below the surface of the bed. Therefore this point has to be carefully considered. A little loam - not manure-is then sprinkled among the roots, and pressed gently round and over them. The rest of the hole is filled up, and the plant made quite firm, first by the hand and then by the foot, and if necessary a little manure, used as a mulching, may be put round it on the surface, 
and covered with a light layer of soil to make the bed tidy. Though I have chosen a Rose as an example, the general system I have indicated applies to all planting of trees and shrubs, special care being taken to arrange the roots with due regard to their natural inclination. If they are too long to lie flat in the hole; it must be enlarged till they rest comfortably without being bent or forced into an unnatural position. If they are deep rooting, the hole must be made deeper. And in planting Roses it is, as I have said, absolutely essential that the collar should be three inches below the surface. For if, as so often is the case, it is above, the briar stock begins to throw up suckers, taking all the nourishment which should go to the scion, and eventually destroying it. I was called in last Summer by a friend, whose charming garden is one of my pilgrimage places here when I want refreshment mental and horticultural. She desired an opinion on her Roses, which she said had nearly all failed, and she was sure the only thing was to take them up and burn them. Happily I 


\section{SOILS, PLANTINGS, PRUNINGS 3I}

arrived in time to prevent such a holocaust. The trouble was simple enough. Instead of the collar of the unfortunate Roses being three inches below, it was three to four inches above the surface of the bed. And though the poor dear things, thus mounted on stilts, were making a gallant fight for existence, another year must have seen an end to every one. As my friend had just got in a fine heap of my favourite turfy loam, I prescribed a good dressing of it at once round each plant, to be followed by thurough renovation of the whole soil in November, and rather close pruning in April; which remedies will, I feel confident, give the Roses a new and vigorous lease of life.

And now for a vexed question-the Pruning of Roses.

A hard and anxious task is that of the Rosegrower in March and April. And each year, as my friends and neighbours ask me what rule they should follow, I can only reply, "There is no fixed rule. Let every one do as experience teaches him." For I am as much perplexed at times as any one else during 
that week or two of torment, when I find myself in an ancient gown and apron, armed with thick gloves, and standing, sécateur in hand, before a big Rose bed. While at night long shoots and short shoots, sappy shoots and hard shoots, plump pink buds and crimson leaves, dance in the dark before my weary eyes, renewing the distracting questions that have occupied my mind all day, - What shall I cut? What shall I leave? On no subject in the garden are there such diversities of opinion as on this matter. There are advocates of hard pruning; and others who swear as fervently by light pruning. There are those who hold to early pruning; and others who hold just as fiercely to late; though the old-fashioned plan of pruning all round in the Autumn has been pretty generally abandoned in England. I was, however, surprised to see two or three years ago that in Paris, at all events in the public gardens, it still obtains. The standard Roses round the Louvre, for instance, were all close pruned before Christmas. But though French winters 


\section{SOILS, PLANTINGS, PRUNINGS 33}

are colder than English, when once they break they do it heartily; and spring bursts with a rush that is amazing, and without the late frosts that are so cruel a trial to us islanders; and this may make a difference. Where doctors, therefore, disagree so fundamentally, the bewildered amateur will find that his only safe plan is to go warily, studying the idiosyncrasy of each individual Rose before he can arrive at any satisfactory conclusions. For individual plants, even of the same variety, have their own little ways; and it is only by long and patient observation that we can grapple with them.

The first point to be considered before we begin work is our intention with regard to our Roses. Are we growing them for exhibition or merely for enjoyment? And if for enjoyment, do we want a few very fine blooms, or a quantity of good ones which will look well in the mass, and enable us to use them with lavish hand for the house and for our friends? Of course Roses for exhibition need far more severe pruning and disbudding, in 


\section{4}

\section{EVERSLEY GARDENS}

order to secure the one perfect blossom into which the shoot puts its whole strength. But as I do not exhibit, I leave that part of the question to wiser and more experienced authorities.

Personally I delight in quantity. It is such a joy to cut and cut, day in and day out. To be able to give a handful of lovely half-open flowers to any one who comes into the garden. To take a big box-full for the town-dwellers whenever one goes to London for the day. In fact, it is an excellent plan to pack a bonnet-box with nothing but Tea Roses; for then it is impossible to bring it back empty, and to prevent a positively scandalous waste of space one is obliged to fill it with one of Irène's latest creations in hats from Paris.

Having therefore decided on our intention - namely, enjoyment of quantity-we may begin practice. Although, as I have said, one cannot lay down a set of immutable rules, one or two general precepts may be taken pretty well for granted. The first is 


\section{SOILS, PLANTINGS, PRUNINGS 35}

that weak-growing Roses should be pruned hard, and strong-growing ones lightly. The second, of which it is hardly necessary to remind any fairly experienced Rose or fruitgrower, is that the eye (or bud), to which we cut back, should point outwards, so that the shoots may not fill up the centre of the bush and smother each other. I nearly destroyed a fine standard of La France by neglecting this point one year. Returning down from abroad late that Spring, I found so many flower buds already formed, that I was weak enough to shrink from what seemed a positively herodian massacre. And it took the tree two years to recover from my folly.

In favourable seasons our work begins in March, with the Hybrid Perpetuals, some of the most hardy being pruned first for early blooming. The shoots of strong growers such as Ulrich Brunner, Frau Karl Druschki, Margaret Dickson, Mrs. Fohn Laing, Magna Charta, \&c., need only be cut back to a convenient length with regard to the general shape of the plant, and one or two of the 
longest shoots may be gently bent over and pegged down at the tip, if there is sufficient space, which forces them to break from every dormant bud in July. I tried this last summer on two big plants of Ulrich Brunner with delightful results. Short and sturdy growers, such as Baroness Rothschild, should be cut back to the first plump bud. The groups of Magna Charta are kept mainly for the effect of their mass of pink flowers seen against the distance from the dining-room windows. But as twelve dozen really perfect blooms cut for the church one Saturday made no perceptible difference to the appearance of my "three-farthings" Rose bushes at breakfast on Sunday morning, I felt justified the next year in my methods of pruning. After clearing out the old, weak wood, some of the strong upright shoots of the former year are merely cut back to the first dormant bud; and these invariably bring the finest flowers, often four or six together in a bunch at the top, while each eye below flowers in succession.

The Hybrid Teas may be treated much in 


\section{SOILS, PLANTINGS, PRUNINGS 37}

the same way, always bearing in mind the differences of growth and constitution of each Rose. For instance, I was obliged one year to cut a plant of Ferdinand Batel level with the ground, in hopes of persuading him to start again with a little more vigour than he had shown for two years; while large sums would not induce me to take an unnecessary inch from the strong plants of glorious Madame Ravary next to him. Yet when these two Roses first appeared they were supposed to be much of the same habit.

We begin early in April on the Tea Roses; and if the wood has ripened well, very little pruning is needed; among the dwarf plants only weak and bad wood being removed, and the shoots slightly shortened. But where frost has withered a shoot, it must be cut back to thoroughly sound wood. With climbing Teas as much healthy wood as possible should be preserved, the side shoots on one or two year-old wood being shortened back to two or three eyes where advisable, to prevent overcrowding. But with all Teas it is well 


\section{EVERSLEY GARDENS}

from time to time to cut an old shoot right down, thus inducing the plant to throw up young wood from the bottom. Many of the Teas and Hybrid Teas, if pruned very sparingly, soon form bushes four feet high and as many through: Tillier, Amabilis, Marie Van Houtte, Baronne de Hoffmann, Viscountess Folkestone, Gloire Lyonnaise, Gruss an Teplitz, Caroline Testout, and others, lending themselves to this form of growth with excellent effect.

Noisettes are treated in the same way as Climbing Teas. The delightful Ramblers, one of the joys that have invaded our gardens in rapid and seemingly endless succession of late, must be allowed to grow at their own sweet wills, care only being taken to remove old growths bodily when they show signs of failing. The same system applies to the Ayrshires, Evergreens, Wichurianas, and Penzance Sweet-briars, each in their own position, whether covering the ground or in bushes or climbing up walls, trees, or arches.

The Rugosas only require to have the 


\section{SOILS，PLANTINGS，PRUNINGS 39}

remains of last year's flowers and fruit nipped off the end of the shoots, with an occasional shoot cut hard back to make it break below; while with China, Bourbon, Briar, and Dwarf Polyantha Roses, hardly any pruning is necessary, if dead wood is cut out and the centre of the plant left clear.

But Moss, Damask, and Provence Roses must be pruned fairly close-the strongest shoots being left longest - and the plants should be generously fed, if we wish to get the best results from them. This probably is why the dear old Red Damask, the Cabbage, and the Pink Moss always do so well in kitchen garden borders. For whatever else may be starved, vegetables must have plenty of nourishment. 


\section{CHAPTER III}

THE SPRING GARDEN AND ITS BULBS.

As we of the older generation look back on the Springs of our childhood, they seem to be fraught with such balmy breezes, such sunny days, such wealth of flowers as we never see now. And then comes a real Spring to give our ungrateful hearts the lie; and Eastertide once again proclaims that the yearly resurrection of the earth is indeed a true symbol of the Feast we celebrate, when leaves and flowers spread a glory over all the land. Such a Spring, such an Easter, despite a few cold days, seem ours this year (1905). Never has the country looked more lovely than it does to-day-its green hedges powdered with gold of Gorse ; the Wild Cherries hanging like snowy clouds among the woodlands that blush green and pink and brown with opening buds, above 


\section{SPRING GARDEN AND ITS BULBS 4I}

beds of Wood-anemones set thick with pale Primroses. The sheets of Lent Lilies linger, even while

"The Swallow dares,"

and bid good-morrow to the first Blue-bells that will soon carpet the copses with heavenly blue; while in the meadows golden Kingcups mark each watercourse; the "freckled Cowslip" fills the air with its honey-sweet scent; and even the Fritillary is beginning to raise its strange snake's head above the growing grass.

If the wild woods and meadow-lands are thus dressed with delight, how great is the enchantment of our gardens! Every poor man's cottage, every rich man's house, stands alike in a jewelled setting. Ruby, coral, pearl and topaz of Tulip, silver of Arabis, sapphire of Anemone, onyx, jasper and sardonyx of Auricula, Polyanthus and Wall-flower, and gold, everywhere gold of Daffodil. For flowers are no respecters of persons; and whosoever loves them, be he king or beggar, to him do they respond and give of their 
best. As I passed a poor widow's cottage yesterday, yellow Crown Imperials stood in long ranks beside the walk, a vision of stately beauty not soon to be forgotten. In the little front garden at the corner of the Green, the two round beds that make so brave a show in Summer when filled with tall Fuchsias (wintered in the larder) and Begonias, are now as brave with close-planted circles of Chrysolora, Cottage Maid, and Artus Tulips round a centre of choice Wall-flowers and Daffodils, all grounded with handsome Pansies. While a border outside the back door, only seen by those privileged to share the friendship of the dear owner, is even more attractive with its great clumps of Polyanthus and Narcissi. Hyacinths which were used in pots in the house come up in it year after year, with "Butter and Eggs" brought from the old Farm on Bramshill Common when the home there was broken up. Each plant has its history, is loved and cared for, and flourishes in consequence. In another muchloved and much-tended garden close by, the 


\section{SPRING GARDEN AND ITS BULBS 43}

walks were marked out as I went into it with hundreds of "Butter and Eggs"-or, as they are now called, Golden and Orange Phœnixand scores upon scores of the double Queen Anne's Jonquil. No new importations are these, even from the best seedsmen's catalogues; for they have grown on, "coming up where they please," as their owners say, for the last forty or fifty years. And so has that beloved and capricious creature Anemone fulgens, which overruns the borders and appears among the Raspberries and Cabbages behind them.

A charming Tulip is Cottage Maid; sturdy and even in growth, it is one of the most satisfactory of all for bedding purposes, with its clear pink and white set in the grey green leaves. At this moment it is in beauty in the borders up to my gate, rising out of a carpet of double white Arabis below the redbrown leaves of the Tea Roses, among which a pair of white-throats, just arrived from Morocco, are busily searching for green-fly, while a couple of Tom-tits flash hither and 


\section{4}

\section{EVERSLEY GARDENS}

thither like sapphires, intent on the same excellent work. The borders round the house are always gay now with a wide band of Polyanthus of every conceivable shade from snowwhite to rich deep crimson, backed with dark Wall-flowers. Much as I detest "fashions" in flowers, I rejoice that a taste for the beautiful and useful Polyanthus has revived; for during long years of neglect it was thought only worthy of the children's little gardens, or the cottager's border. Few flowers are so easily cultivated; and when once a good strain has been established there is no difficulty in increasing it by gathering and sowing the seed in June, while the old plants are lifted and set in close rows in a cool place till they are wanted again for autumn planting.

One's neighbours' gardens are full of interest and suggestion in this budding and blossoming time of year. And hardly a week passes without gleaning hints or extracting promises of cuttings or offsets. In the Spring of I906 I got many hints in a delightful garden, where, between straight-clipped hedges of Laurel, of 


\section{SPRING GARDEN AND ITS BULBS 45}

Yew, of Beech and of Nut, green paths lead into and through the wood that is thickly spread with white stars of Anemone, pale Primroses, and blue Dog-violets. In a border under the balustrade of the terrace, groups of the beautiful single Tulip, Proserpine, were set among yellow and deep velvet-brown Polyanthus, a striking and effective combination. And a rustic basket on the lawn was delightful-though rustic baskets are usually but little to my taste -in which pale blue Hyacinths rose out of a mass of double white Arabis. It fairly foamed over the sides of the basket; and the flowerspikes were so unusually large that I was curious to know how it was treated. Its owner simply cuts it close after it has flowered, and she finds this promotes much stronger shoots and flowers for next season.

How far more beautiful are such combinations of bulbs with a grounding of some dwarf growing flower, or other bulb, than the bed of merely one kind of Tulip, Hyacinth, or Daffodil. It lies practically bare for four months after planting; and though gorgeous 


\section{EVERSLEY GARDENS}

in colour for a fortnight, or three weeks at most, then becomes a melancholy waste till summer bedding begins. The bulb beds at Hampton Court, for instance, which are always grounded with some dwarf flower, are infinitely more effective than those down the east side of Hyde Park, while a quarter of the quantity of bulbs are used. What can be more exquisite than a bed of the yellow and orange Hyacinths-which are curiously neglected by many lovers of bulbs-rising from a groundwork of Scilla Sibirica or Myosotis dissitiflora; or one of Auriculas, kept to shades of purple, and starred with Narcissus poeticus. I was much taken with the deep blue of the Grape Hyacinth planted lavishly among a thick double line of white and yellow Polyanthus, which made a most striking edging to a long shrubbery border in the Public Gardens at Bournemouth last Spring. While in the wild part of the Garden of Delight, I shall not soon forget a plantation of the mysterious white Trillium grandiflorum in the carpet of indigenous Bluebells that spreads under the trees; its place 


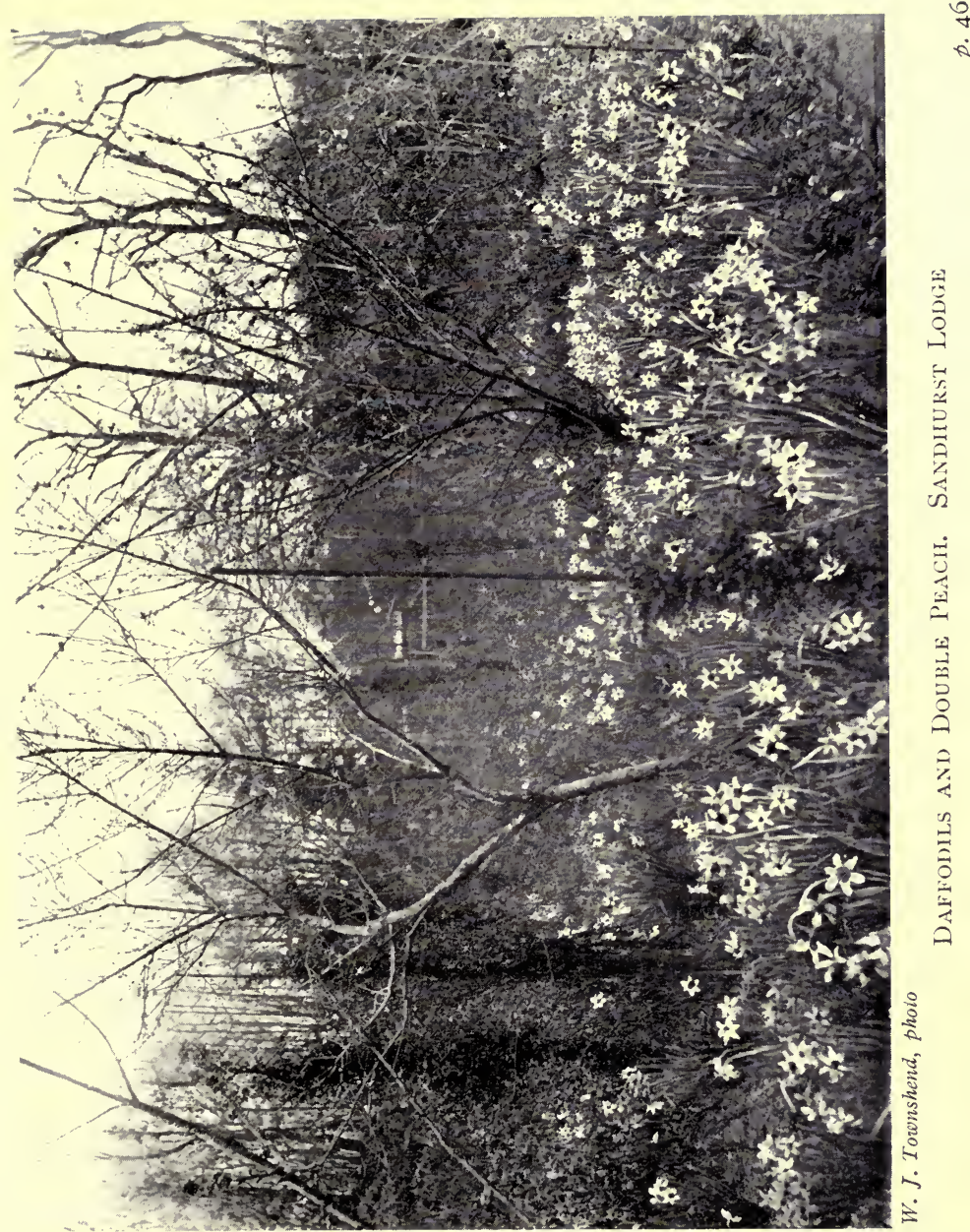





\section{SPRING GARDEN AND ITS BULBS 47}

taken further on by the pale yellow of late Star Daffodils. And in another part a troop of Grandee, the latest of all the bicolour Daffodils, rose out of a mass of Forget-me-nots. Polyanthus, Primrose, Aubretia, Alyssum, Arabis, $\mathrm{d}$ warf Phloxes, Forget-me-nots, of which there are now so many lovely varieties, Pansies and Violas, and above all, Auriculas, form a perfect groundwork for bulbs. And as all are fairly easy to grow, they are within the reach of all garden-lovers.

Each one of us, I suppose-even the gardener - has his own little secret points of conscience in the matter of economy. Purely arbitrary and conventional though they may be, he dares not disregard them. B may think nothing of paying $£ 20$ for an etching, or $£ 50$ for a scrap of china, or $£ 100$ for a snuff-box, while he shudders with honest dismay at the bare idea of 7 s. $6 \mathrm{~d}$. for a new Rose. C cheerfully spends large sums on his stables or his greenhouse, while he will waste hours of valuable time in saving every morsel of string off his parcels, to avoid the hideous extravagance of buying a 
fourpenny ball of twine. These conscientious economies are vastly entertaining in one's neighbour; but they are quite a serious matter to oneself. And the gardener has need to keep them well in mind, especially when he visits other gardens or when the alluring Exhibitions begin to show him what novelties other people are growing, if he intends to look himself straight in the face when he stands before his glass.

Though I must confess to being something of a spendthrift in my garden, there are certain enchanting snares I have managed fairly to avoid so far, well knowing that, if once they were freely indulged in, the Bankruptcy Court would soon loom large. New Roses I cannot resist, though, happily for me, want of spaceunless fresh beds are made twice a yearpartially controls the sweet extravagance. But I have never been reckless enough to "go in for bulbs," as the saying is. For if one's foot is set on that perilous slope, the descent into an abysm-a delightful and flower-bedecked one, I grant-of wild expenditure is indeed easy and rapid. That the snare is no new one, 


\section{SPRING GARDEN AND ITS BULBS 49}

the history of the celebrated Black Tulip shows; and surprising sums are still asked and given for certain Daffodils. There are rumours from those who know of $£, 40$ to $£, 50$ for a single seedling raised by famous growers, from which it will take years to raise a sufficient stock to place it on the market. And, in any good catalogue, prices ranging from 2s. 6d. to $f_{\mathrm{I}}$ for one small bulb are not unusual. Therefore, when half-a-dozen of beautiful Madame de Graaf or Gloria Mundi at 2s. 6 d. and 4 s. 6 d. a bulb are needed to fill a good show-pot, the cost becomes considerable.

My bulbs thus far have been limited to a few hundreds of the cheapest Tulips, Narcissi, and Spanish Iris. I began with a few Emperor, Empress, and the invaluable Stella - rightly named, for a group of its creamy stars shine out delicately above the full green foliage opposite my window, to cheer me as I sit writing. In I904 I planted a hundred, and the bulbs multiplied in an extraordinary manner, having more than doubled in number by the next year. They were all lifted and 
carefully dried off in the summer; and except for those permanently planted in grass or in the wild garden, I have certainly found this plan succeed best, though I know there are two opinions on the subject. But l'appétit vient en mangeant. Not content with these, I was obliged to get a few more in I905. I chose the cheapest - a modest 300 of Princeps Maximus, Barrii Conspicuus, and Duchess of Brabant. They were enchanting.

"Indeed, indeed repentance oft before I swore-

And then and then came Spring, and Rose-in-hand My thread-bare penitence apieces tore."

And then I must needs get just a very few fresh ones. Sir Watkin, grandest of Medium Crowns; Mrs. Langtry, exquisite with white perianth and citron cup; Golden Spur, the fine yellow self trumpet so invaluable for pot-work; Horsfieldii, as handsome, but earlier and more dwarf than Empress; and the magnificent Grandee, latest of all. There I have stopped, just in time to save my tottering self-respect. But who knows whether some day Cernuus and 


\section{SPRING GARDEN AND ITS BULBS 5 I}

Madame de Graaf may not prove too much for me. A pure white trumpet Daffodil is indeed a flower to dream of.

All my bulbs, however, do not go at once into the garden. Never has winter slipped by so quickly and cheerfully as it has since I began three years ago to grow bulbs in peat fibre. For every room in the house, kitchen and servants' hall included, is now gay and fragrant from the time the last outdoor Chrysanthemums are cut by frost, to the radiant March days when bees, busy among Crocus and Polyanthus under the open window, remind us that- "Lo! the winter is past. . . . The flowers appear on the earth. ... And the voice of the turtle is heard in our land," and this has been accomplished at the cost of a little care and a very few shillings, without the aid of a scrap of glass.

Of course we have all known from earliest nursery days that Hyacinths can be grown in glasses, and that they, with Tulips, Crocuses, Daffodils, Freesias, and other bulbs, if potted or planted in boxes early in the autumn, placed 
in a cold frame or under a north wall, and well covered in ashes or coconut fibre, can be brought into the house to develop when well rooted. But the growth of all these is slow as compared with that of bulbs planted in peat fibre, and grown in glazed pots, bowls, or vases, without drainage. The rapidity with which they bloom is astonishing. There is no mess of overflowing saucers-no heavy pots to mark finely polished furniture, no sour smell of damp earth. And by planting them in succession, the house, as I say, is gay with lovely flowers from November till spring. Especially do the delicate and charming early white Roman Hyacinths lend themselves to this treatment. My plantings of them and other bulbs begin in the end of September and beginning of October. This ensures a supply of the Hyacinths from early November.

Any china or pottery bowl may be used, no matter how precious, for the fibre does not stain it. A lump of charcoal the size of a walnut is placed at the bottom, and the bowl filled three parts full with fine peat fibre and 
SPRING GARDEN AND ITS BULBS 53 crushed shell, which must be thoroughly wetted, but not enough to turn it into a bog. ${ }^{1}$ The bulbs are then gently but firmly pressed into holes in the fibre till they are three parts covered. A little loose fibre is sprinkled round them, and the bowl filled up with good fresh Sphagnum from the nearest bog. If this cannot be procured, fresh feathery moss or pebbles will do. The bulbs, whatever they may be, should be placed as close together as possible, without actually touching; and the more cramped the space in which they grow, the better they flower.

The pots are then placed in some cool, darkened place, where they can get plenty of fresh air. This is essential. The old plan of starting bulbs in a close dark cupboard does not agree with those grown on this system. Mine are all put under a table covered with a thick dusting-sheet in an empty, fireless dressing-room. They should be watered sparingly at first; twice

${ }^{1}$ I generally obtain this, as well as the bulbs, from Dobie, of Heathlands, near Chester. 


\section{4 EVERSLEY GARDENS}

a week is sufficient to keep the fibre moist. When they are thoroughly rooted, and not till then, they are given more light to develop the foliage; and as soon as flower buds begin to show they are placed in full light, in a window-sill in a cold room, till they go to their final position in the rooms. The roots are so strong at the end of a week or ten days that they often lift the bulbs right out of the fibre, when they must be carefully and firmly replaced. With Roman Hyacinths the flower buds show a fortnight to three weeks after planting.

In 1905 my first batches were planted on September 25 and October 5; followed by others on October 20, November 16 and 26. And on September 27 I planted exactly the same kinds in the ordinary pots of good soil, and plunged them in a cold frame under coconut fibre. This enabled me to compare the methods. The Roman Hyacinths in fibre were in flower five weeks and two days from planting, and kept the house fragrant and delicately gay till the middle of January, to 


\section{SPRING GARDEN AND IT'S BULBS 55}

say nothing of the bowls I gave my neighbours at Christmas instead of tiresome cards. In December some bulbs of the charming little Scilla Siberica began to show flower buds, and they were out on January 6. I had planted some among the first of the Roman Hyacinths, but these were over long before the Squills were out; so I lifted the little blue treasures and replanted them among some of the later Roman Hyacinths-making a lovely combination in January. Roman Hyacinths in the frame were so unsatisfactory that at the end of a month, as they refused to move, I replanted them in fibre, when they immediately started on gaily, one bulb in a tiny single pot bringing no less than seven spikes of flower.

As to coloured Hyacinths, those grown in fibre are a week or two earlier, and white and purple Crocus a month earlier than those in pots of soil. Tulips take about the same time under each system. Of Narcissi, the first to flower is the delicious Double Roman Polyanthus Narcissus. A big brass bowlful 


\section{EVERSLEY GARDENS}

planted on October 9 was in flower on December I7, their honey scent evoking visions of a boggy meadow outside Genoa at Eastertide, where they grew instead of rushes. Next came the Daffodils, which are much slower; and another year I will try planting them in August for Christmas blooming. Duchess of Brabant took four months from the date of planting. Emperor, Sir Watkin, Golden Spur, Princeps Maximus, Empress, Horsfieldii, and Barrii Conspicuus take about the same time. Grandee and Mrs. Langtry are both a little later. Grand Monarque is latest of all, having only beaten those in pots by about ten days; while the others are several weeks in advance of those in potting soil.

But by far the most interesting and surprising result of my experiments has been in Freesias. On October 5 I planted a quantity of bulbs in fibre in a little Dresden bowl, and others in ordinary soil. On January 24 those in fibre were in flower, lasting on for four weeks, a joy to their owner and the envy of 


\section{SPRING GARDEN AND ITS BULBS 57}

all beholders. Those in pots only began to show a few flower buds on February 7, and were not in bloom till the middle of March. And more than this, the size of the flowers grown in fibre was most remarkable-far larger than some I saw near by grown in pots, with every advantage that heat and a skilled head-gardener could bestow.

Comparing various Daffodils planted from the same stock under both systems, those in fibre are undoubtedly superior in size and colour, and last longer in bloom. This I demonstrated last year at a little bulb competition I started for our school children. I planted an old blue and white Dresden soup tureen of very graceful shape, with Princeps Maximus in fibre. When I showed this at the school-a marvel of cream and gold from eighteen to twenty glorious flowers- the expert visitors could hardly believe that the bulbs had come out of the very same bag as those the little gardeners had grown-and grown admirably-in pots. But really the children's bulbs fairly astonished the visitors, so great was 


\section{$5^{8}$ EVERSLEY GARDENS}

the improvement on their first essay of the previous year. Twenty-three boys and girls competed; and when I distributed the bulbs -a Hyacinth and two Daffodils to each-I gave them exact instructions, which they repeated viva voce, as to how to pot and treat them. The children were on their honour not to receive any help at home; and loyally did they abide by the conditions. After the Christmas holidays the pots were brought up to the school and placed in the class-room windows, each child watering and tending their own; and better grown flowers I have seldom seen. The only difficulty was how to choose the prize-winners.

Last but not least among Spring bulbs, prolonging bulb time into Pœony and Rose time, and giving us finely decorative flowers just at a moment we need them, come the May-flowering Tulips. The old "Cottage Tulips" of our childhood have been wonderfully developed of late years. And now, besides the common violet-crimson, which used to grow so freely in the Rectory garden, 


\section{SPRING GARDEN AND ITS BULBS 59}

we get among many others the White Swan; the sweet-scented, orange-red Macrospila; Gesneriana major, a grandly decorative flower of deep scarlet with a blue-black centre; the lovely white Picotee, with its rose edge; and Golden Crown, one of the most effective of all in the garden when grown in long lines or large clumps. The only fault of the fantastic Parrot Tulips is that they tumble about the border in such an absurd fashion, that their gorgeous colours are too often smirched with mud after a shower: but for brilliancy and intensity of shades they are unequalled. And last and finest of all, the grand Darwin Tulips, erect on their tall, strong stems, are hardly over in the Garden of Delight where they are planted in the Rose beds, before the Roses themselves begin. 


\section{CHAPTER IV \\ MAY GARLANDS}

Opening with Cherry, Plum, and Apple blossom, and closing with early Roses and all the glories of Azaleas and Rhododendrons, the month of May, if the weather be kind, is garlanded from first to last with flowers on bush and tree. Lilacs, Hawthorns of every shade, Guelder Rose, both the ordinary Viburnum sterilis, and the Japanese $V$. plicatum, most decorative of shrubs, mingle with the white spires of Horse Chestnut, the "golden rain" of Laburnum, the stars of Magnolia, the snowy wreaths of Spiræa. And by dint of a little judicious planting, the smallest gardens may produce a succession of delightful colour effects till "flaming June" showers them over with her wealth of Roses.

First in the lovely procession come the 
Plums. The dreaded Blackthorn powdered every hedge with its untimely winter last month: but there are Plums in the orchard, and the many choice varieties cultivated for their flowers in our gardens. Prunus Pissardii is, indeed, nearly over by May Day, and its delicate little pink blossoms are falling as the pinky-brown leaf buds open which will soon turn to rich dark foliage. But it is quickly followed by $P$. spinosa $f$. pl., the doubleblossomed Sloe, which makes a fine object if grown as an isolated bush on the lawn; for it is as closely covered with snow-white flowers as its wild brother in the hedge. The beautiful $P$. Sinensis $f$. $p l$., with white or rosy-red flowers, is one of the many treasures we owe to Japan; and even more striking is $P$. triloba, with its handsome double pink flowers and bright green leaves; while the double white $P$. Plantieri must by no means be forgotten. Many of these choice Plums create a charming effect if grown in pots in a cold house or shed, or out of doors in a sheltered corner, and then sunk in the grass 
when nearly in bloom, with flowering Cherries and Apples.

Then come the Apples and Crabs. What is more lovely on this dear earth of ours than an Apple orchard in full bloom? A railway journey through the Vale of Evesham, or among the orchards of Somerset and Devon, is one long enchantment in this wondrous season. In our old Warwickshire garden, May brought us yearly a marvellous Apple-blossom show. Two ancient espaliers of Reinette de Canada, known to be some two hundred years old, grew on either side of a narrow path in the kitchen garden. The short trunks were as thick as a man's body. The horizontal stems were as large as trees, respectively 70 feet and $6_{4}$ feet long, and turned round the corners of a cross walk. The upright branches had grown into an arcade 15 feet high, meeting overhead, and when the flowers were out formed an exquisite tunnel of pink and white and tender green, almost shutting out the blue sky above. I was once imprudent enough to write a short description 
of this lovely sight in The Garden, to accompany a charming drawing by my friend $\mathrm{Mr}$. Alfred Parsons, A.R.A., who had been so fascinated by the arbour of blossom that he spent a whole day's work upon it. But it is perilous to let the public into one's little private joys! And I almost repented in subsequent Springs, when swarms of known and unknown visitors asked to see my Apple trees.

If the wild Crab Apples, decking hedgerow, wood, and common with their wealth of pink and white, are in beauty just now, their garden cousins, Pyrus malus foribunda, atrosanguinea, spectabilis, Parkmani $f$. pl., and many more exquisite varieties, are indeed miracles of colour. Floribunda is well named; for the graceful flowers borne on long slim footstalks, grow so thickly that each branch, each twig, is a veritable garland, covering the whole tree in a fairy cloud of pink, white, and crimson.

Though this bit of Hampshire is, as I have said, by no means a good Cherry country 


\section{EVERSLEY GARDENS}

as far as garden and orchard kinds go, oddly enough the Wild Cherry flourishes amazingly in wood and hedgerow. The enormous old Cherry tree at the foot of the Mount, though sadly broken and disfigured by storms and age, still shows a cloud of white on its remaining branches in spring; while several great round-headed trees in Eversley Wood rise like domes of some snow-built mosque above the flushing green of the undergrowth. When the wild and orchard Cherries are still in bloom in late April and early May, fresh delights unfold for us in the single and double garden varieties. Cerasus avium (sylvestris), the double-flowered Gean, with its profusion of snowy blossoms, is followed by $C$. vulgaris $f$. pl., and its improved form C. ranunculiflora. The exquisite blush, pink, and rose-colour of the Japanese Cherry, C. pseudo-cerasus, explains to those of us who have never reached that Farthest East the enthusiasm that reigns in Japan during the famous Cherry-blossom feasts; and with its many double and semidouble varieties, Fortunei, Siebolti, Watereri, 


\section{MAY GARLANDS}

Fames H. Veitch, \&c. make it one of our most valuable flowering trees. While the lateflowering American Bird-Cherry, C. Serotina or Virginiana, prolongs the season of this delightful family into Azalea and Rhododendron time.

Let us not forget-who, indeed, can forget them who once has seen their lovely deep pink blossoms burst from the bare, leafless twigs among the vineyards of Southern France?the Peach and the Almond, marvels of colour against the blue of sea or purple of mountain. Single and double alike should be in every garden. Nor can we do without plenty of the Snowy Mespilus, Amelanchier botryapium, a treasure both in spring and in autumn. Have we not seen the "golden rain" of Laburnum against the grey stone of house and college in Oxford-a vision of beauty that never fades? And, beyond all other delights, a drive just now, no matter where, through the most romantic of parks or the most prosaic of suburbs, is a perfect enchantment; for wild and tame Hawthorn, May's 
own flower, has whitened hedgerow and common once more, and made our gardens so radiant with the pink and crimson of its single and double varieties, that we could almost envy the sweet pain of the nightingale, when

$$
\begin{aligned}
& \text { "She, poor bird, as all forlorn } \\
& \text { Lean'd her breast up-till a thorn." }
\end{aligned}
$$

We are hearing a good deal now about planting for colour effects in the garden, a point which until the last few years has been sadly neglected by all but that limited number of gardeners who are artists as well. I thought one day in late May, as indeed I have often thought before and since at all seasons of the year, that among these gardener-artists the creator of what I venture to call the Garden of Delight stands pre-eminent. For such May Garlands of subtly combined and contrasted colour are seldom seen. We seemed to be stepping through lines of burnished copper and gold between the broad borders down the straight walk-wide bands of Polyanthus in front of Wallflowers of every shade, behind 


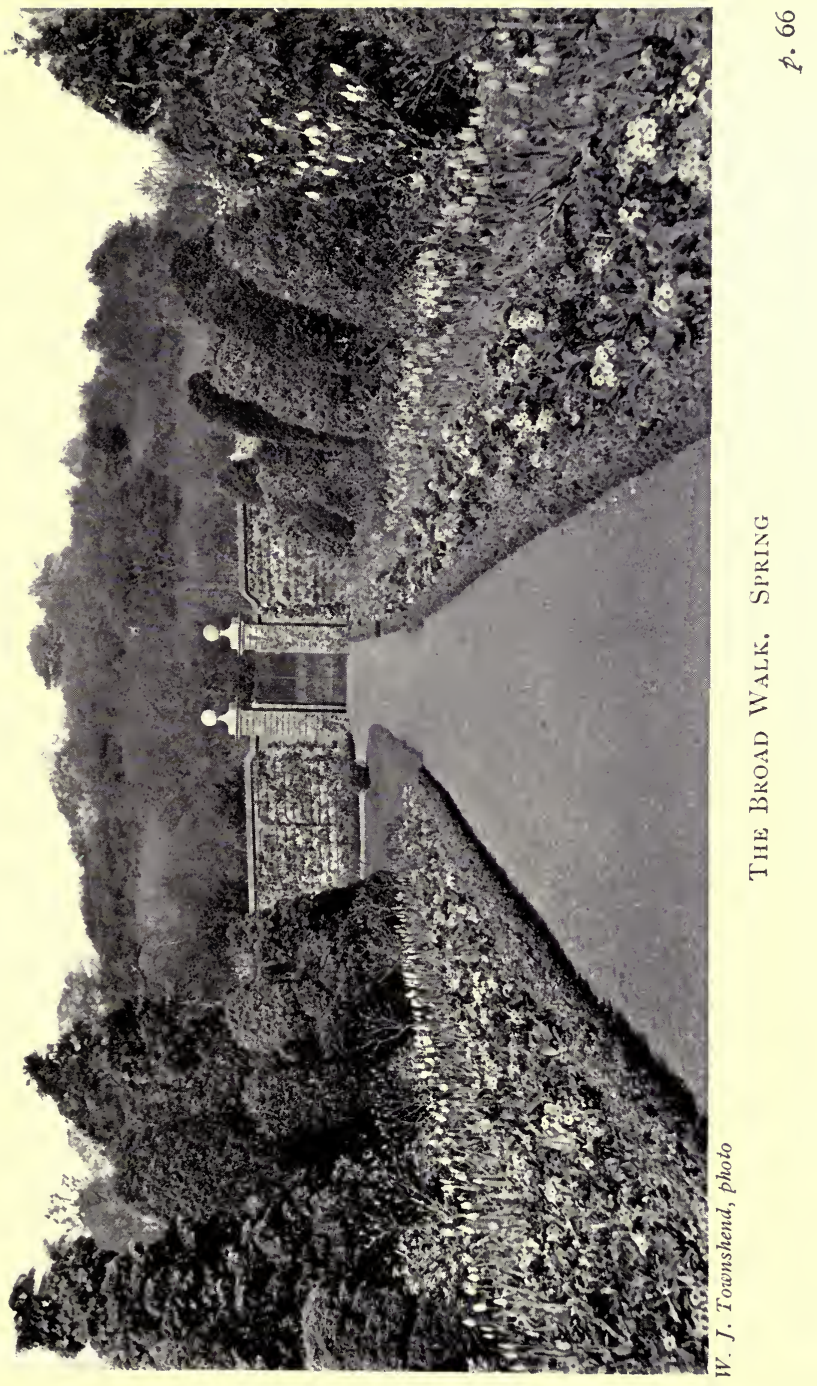





\section{MAY GARLANDS}

which hundreds of Golden Crown Tulips lifted their brilliant heads proudly to the sun. The cool beauty of the Water and Wild gardens came-as it was intended to come-with an exquisite note of repose after this amazing mass of colour. The copse at the end of the Lily ponds had been cut, after the fashion of copses, this year; and for a moment I feared the sense of mystery. it gave might have suffered, until I realised that it only revealed a fresh delight. For the whole steep slope was one thick sheet of Bluebells-a wondrous carpet of intense blue; and against this blue, where in Summer the pink Hydrangeas make a fairy glade, pots of dwarf Apple trees in full bloom were sunk in the turf. The big Pink Cherry above them was nearly over; but bushes great and small of the late-flowering C. Avium shimmered like snowdrifts among the tender green of tree and shrub near by. And along the grass bank beside the Lily Ponds, more delightful Cherries, the double pink James Veitch, the single pink Watereri, with Spircas of many sorts, and Pyrus Malus 
floribunda, atrosanguinea, \&c. were sunk, till the Erythrinas and other Summer wonders should take their place. But there was no lack of vivid colour. For under a great Oak a flaming Tree Pœony gave the lie to critics who, that very week, had found fault with the colour of one represented on paper by my friend Miss Margaret Waterfield. And fiery Azaleas beckoned us onward through the enchantments of the Wild garden by smooth cool ways of green turf, the grass and rockeries on either hand alive with blue of Forget-menot, crimson of Japanese Primula, pure white of the mystic Trillium, the last of the Daffodils, tall strange Tulips, with bulbs and flowers - known and unknown, rare and common-growing among trees and shrubs from all the world over. But when, in the delicious shade of the great forest trees, with woodwrens and warblers singing as if their little hearts must break for very joy at the warmth and the sunshine and the beauty, we came upon a fresh slope of Bluebells starred with Poet's Narcissus, we cried halt. For out of 


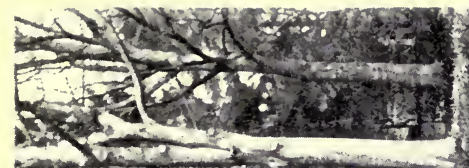

6

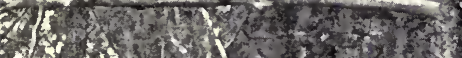

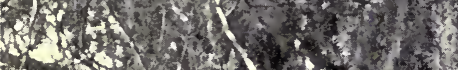

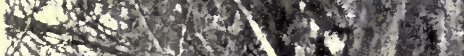

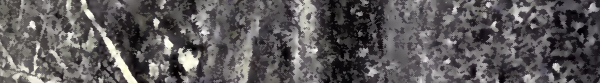
A

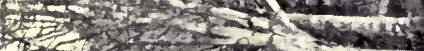

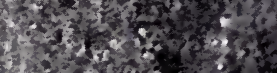

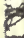

(1)

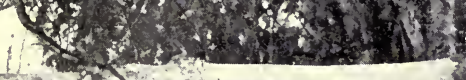

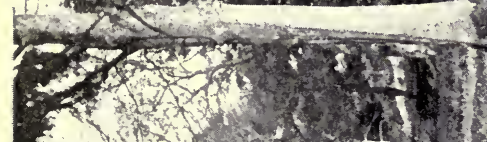

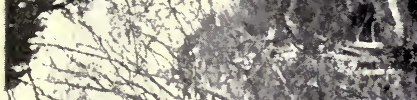

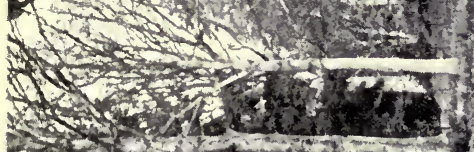

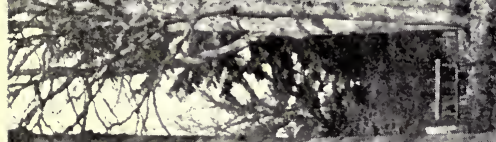

\section{,}

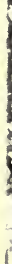

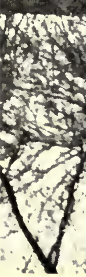

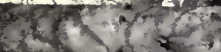

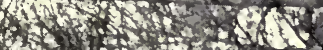

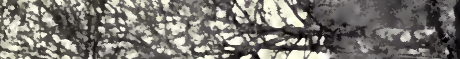

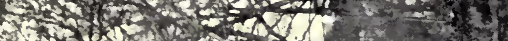

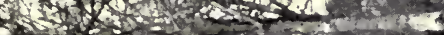

\section{(2)}

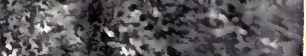

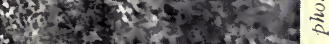

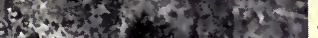

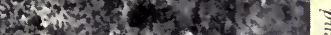

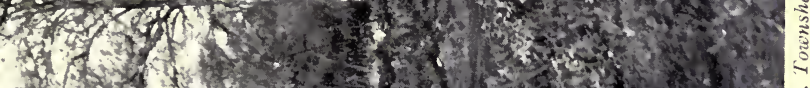

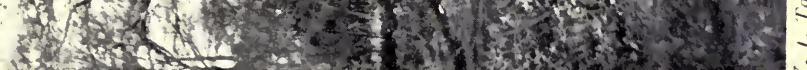
a 



\section{MAY GARLANDS}

the blue cloud rose Azalea Mollis innumerable -flaming bushes, planted sparsely, of every imaginable shade from pale primrose to deep, fiery orange-red. No one who only knows Azalea Mollis-infinitely more beautiful than even the lovely Ghent Azalea-as a pot plant, can imagine its beauty when allowed to grow in the open, or rather, I should say, in semishade. And such a delight is within the reach of us all; for the plants are hardy, cheap, and easy to grow, while a carpet of Bluebells, Daffodils, and Wood-anemones is quickly created about them.

As I have said, the end of May brings with. it these glories of modern horticulture, the Azalea in all its bewildering varieties of colour -white, yellow, flame, orange, crimson-and Rhododendrons. And only those who live in a real Rhododendron country know the full joy and beauty of the time. For although the Hybrid Rhododendron is the most accommodating of plants, growing in almost any soil and any situation, it particularly loves our heather land; and fairly revels in the peaty 
loam of Bagshot with an endless supply of rich leaf mould from the woods bordering Chobham Ridges. While Londoners may delight each year in the Annual Rhododendron Show of Messrs. John Waterer \& Sons in the Royal Botanic Gardens, Regent's Park, a still greater feast of colour is spread for those who live within reach of their famous nurseries at Bagshot, the home of scores of the exquisite varieties known all the world over. As such is my happy fate, it seemed only right one day to pay my devoirs to "Pink Pearl" in its own home. The Red Seraph was badly in want of exercise, too; so we trotted gaily over by the grand old coaching road, now infested by hundreds of motor cars emitting hideous hootings and villainous smells, which have taken the place of the forty coaches that travelled daily each way with their fine teams and merry horns in the old days. But no highwayman, not even Parson Darby or the benevolent landlord of the "Jolly Farmer" himself, could have looked more alarming than the masked motorists who flew past us. The 
Red Seraph did his ten miles in five minutes over the hour; and as we descended the long hill from the "Jolly Farmer" where the Portsmouth and Southampton roads branch, sheets of colour on our right, backed by pleasant woods, showed that we were nearing our goal. These were the younger plants in the main nurseries. But it was not until from the north window of a cool drawing-room we overlooked the "Home Ground," the original nurseries on the other side of the road, that the full splendour of Rhododendron-land burst upon us.

Never was spot more wisely chosen than this, by the wise founder of the famous firm well-nigh a hundred years ago. And the charmingly broken ground, sloping sharply away north and west from the house and then rising gradually towards the Church and Bagshot Park beyond, is peculiarly well suited to show off the full glory of colour as one looks down on it. A glory it certainly is at this time of year: mountains and cliffs of pink, white, crimson and purple under the bright 


\section{2}

EVERSLEY GARDENS

sun, with here a fine Copper Beech, there a gigantic Deodar rising out of the mass of flowers, and all set off by the rich green trees of the Park.

But magnificent as the general effect is, the individual plants must be seen close to appreciate their full beauty. Many of them are forty and fifty years old, great trees planted in the days of the father and grandfather of the present generation, and left to form huge walls of green leaves and brilliant blossoms over twenty feet high. Perhaps one of the most remarkable effects was produced by immense masses of the clear, warm rose with dark crimson spots of Lady Eleanor Cathcart, by no means a new variety, but one of the finest. I can only describe it-Oh bathos!as a mountain of Cherry water-ice. Then next would come a mass of the pure white with purple-black blotch of Sappho, the fiery crimson of Frederick Waterer, or rich crimson of Fohn Walter.

On that particular visit I made a list of the kinds that struck me most, for the benefit of 


\section{MAY GARLANDS}

those who have not chanced to see these delightful grounds, or the exhibits at the Temple Flower Show, or the display in Regent's Park. For I was so filled with enthusiasm before such wondrous developments in colour and form, that I longed that others, even from a dull description, might appreciate them to some small extent. And this enthusiasm has only been increased, and my choice of varieties confirmed, by subsequent visits.

The famous novelty Pink Pearl stands alone; a crowning triumph to three generations of patient scientific work in hybridisation. Never was name more appropriate than this; for the enormous flowers are exactly the colour of that most delicate and rare of jewels, a pink pearl. One of its parents is the grand Himalayan Rhododendron, R. Aucklandi (syn. Griffithianum), a white or blush-coloured species growing to the size of a tree. And this, one imagines, might make it somewhat delicate; for the $R$. Aucklandi is even more tender than the grand $R$. Arboreum, the Himalayan crimson Tree 


\section{EVERSLEY GARDENS}

Rhododendron, to which all our finest scarlets, crimsons, and rose-colours owe their origin. But Pink Pearl seems to be able to withstand the English winter with impunity, though it comes into flower rather earlier than most other hybrids. Other pink Rhododendrons of special beauty are Lady Eleanor Cathcart, Lady Howe (a fine standard), Marchioness of Lansdowne, Mrs. Fohn Penn (a salmon fringed with crimson), Strategist, Surprise, Concessum, Towardianum.

Crimson and scarlet: Sunshine, W.E. Gladstone, Mrs. Tritton, Mrs. Fohn Waterer, Frederick Waterer, Charlie Waterer, Duchess of Bedford, Fohn Walter, Lord Eversley, Earl of Shannon, Doncaster (one of the brightest scarlet-crimsons known), and Kate Waterer (one of the most beautiful of all, which should be found in every garden).

White and blush: Album elegans, Delicatissimum, Francis B. Hayes, Gloriosum, Gomer Waterer, Lady Clementina Walsh (the buds and edges pink), Glennyanum (light pink), Madame Carvalho, Mrs. Fohn Clutton, Mrs. Tom Agnew, 


\section{MAY GARLANDS}

Papilionaceum, Princess Christian, Sappho, John Henry Agnew.

These of course are but a tithe of the magnificent varieties grown at Bagshot: but they struck me as some of the very finest. I have confined my list to the white, pink, and crimson, because they are less generally grown than the many shades of mauve and purple; and, with the exception of Pink Pearl, they are fairly lateflowering sorts.

A list of some of the earlier-flowering Rhododendrons has kindly been given me by $\mathrm{Mr}$. John Waterer, placed in order of blooming. The earliest of all is Nobleanum-various shades of crimson.

Ascot Brilliant.

Sun of Austerlitz, bright scarlet.

Prince Camille de Rohan, good rosy pink.

Limbatum, clear white ground margined with crimson.

George Hardy, magnificent white.

Cynthia, rosy crimson; one of the best.

Pink Pearl.

Grand Arab, brilliant crimson. 
Blandyanum, rosy crimson with fine foliage. Broughtoni, rosy crimson, an immense truss of flower.

Mr. John Waterer has also given me the names of some of the latest kinds :-

Alexander Adie, dazzling rosy scarlet.

Pictum, clear white, with cluster of yellow spots.

Mrs. Fohn Kelk, clear rose.

Lady Tankerville.

Beauty of Bagshot, very fine white, with a decided eye.

Maggie Heywood, a lovely white edged with pink, and bright yellow eye, which is the latest of all.

Thus we see that, with a little care in selection, it is quite possible to extend the season of these most useful and delightful plants over a considerable period, even in cold situations, and to have Rhododendrons in bloom from March till the end of June. As I have said, they will grow in almost any soil. But let the gardener beware of allowing them, in the kindness of his 
heart, to come near stable manure. That alone is fatal to their well-being.

The life history of the modern hybrid Rhododendron is a deeply interesting one. For nearly all the gorgeous modern varieties have been obtained by endless crossings of four species-R. Ponticum, Catawbiense, Arboreum, and Caucassicum. The purple $R$. Ponticum was introduced from the Black Sea districts, a hundred and fifty years ago. And, though we may prefer other shades to its somewhat cold purple, it has played a grand part not only as an ornamental shrub, but as valuable game cover-being rabbit proof. In many places, such as the woods between Easthampstead Ridges and Bagshot Park, Heron Court near Christchurch, and a score of other estates, it has become completely naturalised, seeding and growing as freely as if it were actually indigenous. As a hedge it is invaluable. Thousands of seedlings or cuttings are planted along the flat tops of the turf banks round the Elvetham estate, and 
form excellent boundaries, crested in May with a purple foam of blossom.

$R$. Catawbiense is a species which covers large tracts in North America, and resembles Ponticum in bearing purple flowers. But its colour is altogether warmer; and instead of the narrowpointed, glossy-green leaves of the latter, its leaves are somewhat blunt, of more substance, and slightly rufous on the under side. It has undoubtedly played a more prominent part in the production of fine hybrids than the common Ponticum.

$R$. Arboreum, the grand Himalayan Tree Rhododendron with crimson or blood-red blossoms, although it cannot stand our winters except in the extreme west of England and favoured positions in Ireland, has proved one of the most useful parents of the modern hybrid. For to it we owe the rich shades of the crimsons, scarlets, and rose-colours we so delight in.

To the fourth species, $R$. Caucassicum, of dwarf growth and white flowers, are due most of the white and blush varieties. 


\section{CHAPTER V}

\section{THE SHRUBBERY}

THE change that has come over the spirit of our gardens in the last half-century is nowhere more evident than in the shrubbery. No longer is it a dismal wilderness of Laurels, with here and there a tired and attenuated purple Rhododendron under the Upas-tree shade of a hearty $\mathrm{Yew}$, the ugly hollow spaces below only cultivated by the dogs, who use it as a graveyard for their stolen bones until they are putrid enough to suit high-bred palates. The modern shrubbery is a very different matter, carefully tended, planted with intelligence and foresight, in order to secure effect, charm, and variety throughout the year.

The number and beauty of evergreen and deciduous shrubs have increased so amazingly 
within the last three decades, thanks in great measure to the opening of Japan with its wealth of hardy trees and flowers, that, with a little thought and for a very small sum, the laying-out of new pleasure grounds and the beautifying of old ones becomes an easy and delightful task. I confess I have such a horror of the common Laurel from past tribulations, that, though it is still useful in many cases, I will not allow one in my garden here. When we first went to the old seventeenth-century house at Tachbrook, in Warwickshire, the garden had been neglected for many years, and the shrubberies were overrun with Laurels. Much labour and many torn garments did they cost me; for they had grown so wild that stacks of dead wood had to be cut out and live wood cut down before they could shoot afresh. But when that was done, and Spring had come, what delighful surprises began to reveal themselves; for coming to the place in Autumn, one could not guess what it contained of charming, oldfashioned plants. The grass walks among 
the Laurels were simply a carpet of Primroses and Violets, with here and there an Oxlip and snowy Wood-anemone. Violets appeared in the ancient steps of a high-lying terrace, and cropped up at the base of walls. Foxgloves, white as well as purple, sprang up among the Laurels. And the fine masses of Lilac and Guelder Rose shutting off the stable-yard, were enabled to flower when freed from the octopus-like Laurels that sucked their life out. There was a disused hill garden lying on a steep western slope surrounded by delicious red-brick walls of I6 I 3 , the same date as the seven-gabled house; and when the monstrous shrubbery in front of it was laid low, the beautiful gateway with brick pillars and stone balls and brick steps by which it was entered, was revealed. That garden had not been dug for seven years, and the Nettles, with

"Hateful docks, rough thistles, kecksies, burs,"

were nearly shoulder high. Though there was a big lower garden under a south wall 
in fair order, I was not sorry when a hard winter and want of work in the village made it a positive duty to get in an extra man to trench it. Espalier Apples and Pears on strained wire up each side of the straight centre walk, and young Pears, Plums, and even Peaches on the walls, soon grew apace; and it was astonishing to see the crops they bore within two years on what was practically virgin soil. The Raspberries were soon so high and strong that small nephews found them a convenient hiding-place in which to gorge at leisure; while a distinguished soldier reminded me only the other day of certain Sunday afternoons he passed almost exclusively in the Strawberry beds.

But to return to the modern shrubbery. In it the detestable Laurel is now almost wholly superseded by the invaluable Rhododendron.

My old Munshi in Scinde sent me a present of shikar one day that he had shot in Godap, on the edge of the desert. It was a cheap gift, as it consisted of two hares- 
unclean animals, which of course he, as a good Mohammedan, could not touch, nor could they be eaten in any self-respecting India Civil Service official's house. In the wondrous letter that accompanied them, a triumph of Indian-English, he informed me that, "One shot in A.M. will, I think, mach the breakfast time, and the one shot in the P.M. can be used at any time. I have tied a tacket to the leg of one shot in evening."

Now Rhododendrons are somewhat like Munshi Mahmud's P.M. hare; they may be used at any time and anywhere, dear, accommodating people. For if a gap has to be filled, Rhododendrons can be lifted even in the midst of Summer to fill it, as their roots do not spread far, and with plentiful waterings they will grow on as if they had never been disturbed. Bewildering in variety, scarlet, crimson, white, pink, and purple, Rhododendrons are an absolute necessity in every garden, large or small; not only for their glory of colour in May and June, but for the shelter they afford where shelter is required, 
for their perfect hardiness, for their immunity from the errant rabbit's teeth, and their generally accommodating ways, suiting themselves to almost any soil, aspect, or climate. When to these we add the flame and gold of hardy Azaleas, it seems as if colour in the modern shrubbery could indeed go no further.

Many other ornamental evergreens add to the effect of the shrubbery. Hollies, green or variegated with silver and gold, smoothleaved or prickly, yellow-berried or red, brighten it through the winter. The Laurestinus, too, in sheltered places is covered in winter and early spring with its white flowers and pink buds. And the Aucuba is indispensable for many an otherwise dark spot, now that we can ensure plants plentifully set with handsome berries, instead of the forlorn and scraggy specimens we associate with front gardens (save the mark) in mean streets.

Of the usual run of "American plants," so called-though many, in fact the greater 


\section{THE SHRUBBERY}

part, are now natives of Australia, China, Japan, Chili, and the mountains of Central Asia-one might write volumes. But who can dispense with the best known among them-with Andromeda, Berberis, Kalmia, Pyracanthus, Phillyrea, Pernettya, and dozens more, large and small? The gold and silver Euonymus, which grows so freely and usefully by the sea, is of great use inland if given a reasonable amount of shelter. I know a rather plain house not far from here, which is now quite a pleasant object in winter, a sheet of silver Euonymus veiling the crude red brick on the south side up to the firstfloor windows. The beautiful Californian Ceanothus, with pale-blue and mauve flowers, and its many hybrid varieties, also does well against walls. But far more beautiful did I think it when, in the gloom of huge Douglas and Sugar Pines, and among the awe-inspiring red columns of Sequoia gigantea in the Mariposa Grove, we came upon the delicate blue cloud of flowers covering big bushes of Ceanothus. Ah! California in May. What a 
revelation it is, when, as an old Irishman said to me while he watered the horses, "The hills are just painted with flowers."

Several other flowering shrubs from California might well be found more frequently in our gardens. One old favourite, Calycanthus Floridus, the Allspice of our childhood, is now associated in my mind, not only with the Study garden at the Rectory, but with a hairbreadth escape from death in 1874 . For, as we rode by a perilous path along the face of the cliff, high above the Merced River, roaring and raging in flood among beds of Azalea and starry white Dogwood, my good little horse acted the part of Balaam's ass; and, as I tried to force him on, reared and turned right round on his hind legs to escape, not an angel, but a huge boulder, which rolled down from the mountain through the Allspice bushes and must inevitably have swept horse and rider into the river far below. But why is not the grand Fremontia Californica grown everywhere? Hardy it certainly is, and finely ornamental, with its leathery bright yellow flowers. 


\section{THE SHRUBBERY}

One always has one's little ambitions, especially about things that refuse to do in the garden; and one of mine runs to the growing of Choisya ternata and Myrtle out of doors. The first I have tried; the second I shall try, and, I suppose, fail with it as I failed with Choisya. For though I planted it in a sheltered corner it died the first winter; while in the Bagshot nurseries, where it flourishes and blooms twice a year, Mr. Waterer says it is only cut by severe frost once in seven to ten winters.

The beauty of the shrubbery that should serve to set off our bright borders and wellkept lawns, and to modify the landscape of our gardens-for even in half an acre there is plenty of scope for "landscape gardening"greatly depends on a judicious mixture of deciduous trees and shrubs with Rhododendrons and other evergreens. And here our only difficulty is the embarras de choix; for it is easy to drop into a mere catalogue, if one tries to enumerate the scores of flowering shrubs available nowadays. The essential point to be 
borne in mind in creating the perfect shrubbery, is so to plant it, that at all seasons of the year it should be pleasant to the eye with colour and variety of foliage. For in Winter itself it is possible to get other colours than uniform green among our shrubs; while green, again, need never be uniform if we select our evergreens with care; among Rhododendrons alone the variety of tones in foliage is very marked. And even before Mr. Vicary Gibbs read his valuable paper on "Winter Planting" before the Royal Horticultural Society, I had discovered the value of the bare ruby stems of Cornus Sanguinea in the Winter shrubbery. Wild-briars in the hedge and Sweet-briars in the garden, give us a shimmer of crimsonscarlet hips till late in the winter. The bare twigs of Prunus Pissardii are delightful in colour; and the leafless Hawthorn hedge warmly purple; while the silver stems of a Birch among the big Hollies beyond, are set in their own mist of dull-crimson twigs. There may be plenty of colour, rich, delicate, subtle, if we will but think about it, in the Winter Garden. 


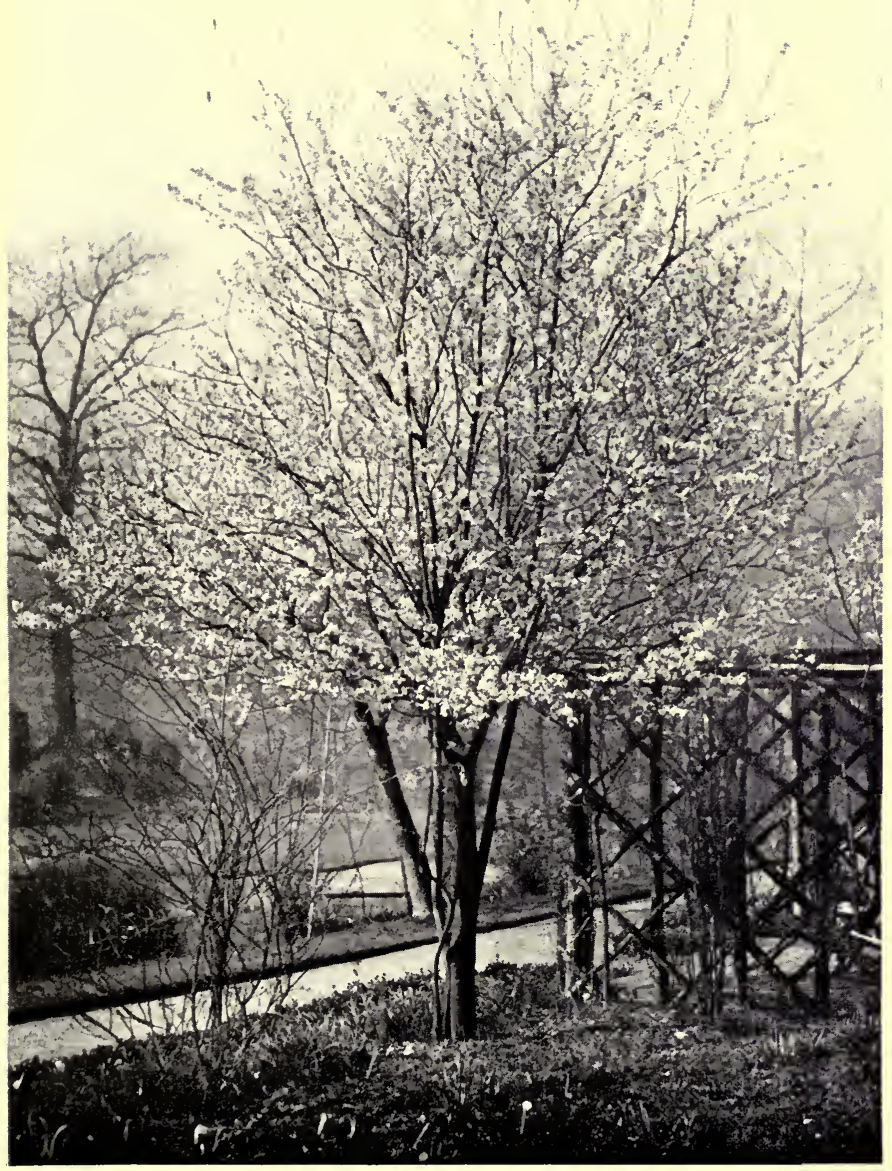

IV. J. Townshend, photo

I'runus Pissaridi. SANDhurst LODGe 



\section{THE SHRUBBERY}

For standards and taller shrubs and trees, we have the enchanting Pyrus malus floribunda, Baccata, Bertinii, spectabilis, \&c. ; and who that has seen a little tree of the graceful floribunda transformed by its myriads of delicate flowers into a cloud of pink, white, and crimson, but would sacrifice much to make a place for it in their garden. And with it we should plant the Crabs; charming alike in flower and fruit time. These, however, are but a tithe of the flowering trees and shrubs which Japan, America, and our horticulturists have given us of late years. There are the pink and white of single and double flowering Cherries, Peach, Almond, and Sloes; flowering Thorns of all shades of white, pink, and scarlet; the rich purple brown of Prunus Pissardii; the silver of Acer Negundo variegata, the vivid greens, purples, and reds of $A$. palmatum and its many varieties; the handsome purple Sycamore; while many of the taller kinds of American Maples add a splash of vivid colour to plantations in the Autumn. But these last must be used with caution; for, if they are not very 


\section{EVERSLEY GARDENS}

skilfully grouped, such American products in foliage, when dumped in England, are apt to look a little crude against our mellow, tempered landscape. And although a Scarlet Maple on the Hudson River or Erie Railroad seems in place with its vermilion and emerald under that "implacable sky," yet against sober British Oaks and Beeches it may savour somewhat of the patchwork-quilt style of planting - a thing to be most strenuously avoided.

Rhus Cotinus, the Venetian Sumach, should be found in every shrubbery; for all through summer its foliage and soft flower-plumes are beautiful, and towards autumn its round leaves take on such delicious tones of pink, red, and green, as to make it a most decorative object. The same may be said of the Snowy Mespilus (Amelanchier), attractive alike in early spring, with its tassels of white flowers which are in full bloom while the leaf-buds are beginning to burst in soft pinky-brown, or when it flames in Autumn.

And Lilacs! I remember when I was 
young, I used to beg and pray our dear old George Chaplin, coachman, gardener, and tutor in general to us children, to spare the Lilacs that grew among Filberts and Portugal Laurels between the road and the stable-yard. For some unexplained reason he hated them; destroying them ruthlessly when he got a chance, and "cutting them over" when he could do no worse, so that they seldom flowered. This, perhaps, made them extra precious in our eyes; and I used to gaze with envy and admiration on the glories of other people's Lilacs - glories apparently unattainable by us. But dear old George-God rest his faithful soul-would not have despised the modern developments of the Lilac, endless in their variety. These, of course, must have a place in the perfect shrubbery. A bush of Charles $X$. is a never-ending delight to me in May, at the corner of a mass of odds and ends I planted to break the swirl of the east wind on the northern side of the house. A huge bush of Syringa-which we are now told to call Philadelphus-stands behind it; and as the 
great reddish-lilac panicles of Charles $X$. fade, the creamy-white Syringa flowers take their place, till they again are succeeded by Roses, Paul's Carmine Pillar and a mass of the white Félicité Perpétuée on a rough arch; and, when these are over, that invaluable Noisette, Alister Stella Gray, planted with them carries on the succession till November. Sweet and early as is the common White Lilac, Marie Legrange is a far finer flower, coming into bloom a little later. Indeed, by careful selection among the newer kinds, the "Lilac season" may be prolonged through a good many weeks. But for actual flower effect few of them can beat a good Rouen, known as Persian Lilac. A cottage garden here last Spring was really a dream of colour from well-kept bushes of Persian Lilac standing at intervals along an otherwise wholly uninteresting border, each a fountain of bloom. To succeed with Lilacs, they should be pruned with great circumspection as soon as they are out of flower, as the blossom is borne on the shoots of the previous year. Due encouragement should therefore be given the plant by 


\section{THE SHRUBBERY}

cutting out old, weak wood in the centre, to let in light and air, and enable it to throw new shoots early enough in the Summer to ripen well, if we wish for fine flowers in the following spring. The soil, too, should be rich, light, and warm, to produce the best results. Cold, damp, heavy ground does not suit Lilacs, though they are wonderfully accommodating : but, like most other living things, care and kindness are not thrown away upon them.

A list of the best Lilacs was given in The Garden of September 9, I905, from Flora and Sylva, and is so valuable that I give it at length.

Singles.-White-Marie Legrange, Princess Alexandra, Frau Dammann, Mme. Moser, Alba pyramidalis. Pink-Dr. Regel, Eckenholm, Fürst Lichtenstein, Schermerhornii, Facques Callot, Lovanensis. Dark flowers-Dr. Lindley, Ludwig Späth, Aline Mocquerin, Toussaint l'Ouverture, Volcan, Phillémon, President Massart, Charles $X$.

Doubles.-White-Mme. Lemoine, Mme. Casimir Perrier, Obélisque, Mme. Abel Chatenay. Lavender and Blue-Alphonse Lavallée, 


\section{4 EVERSLEY GARDENS}

Président Grévy, Lamarck, Léon Simon, Monument Carnot, Condorcet, Doyen Keteleer, Guizot, Marc Micheli. Dark Shades-Charles foly, Colbert, Georges Bellair, La Tour d'Auvergne, Souvenir de Louis Thibaut, Maréchal de Bassompière. Rosy Lilac-Mme. Fules Finger, Rosea grandiflora, Émile Lemoine.

The Syringa, Philadelphus, or Mock Orange, is not now confined to the one dear old species of our childhood. This has been improved by hybridisation and selection until the flowers, while just as sweet, which is not always the case with new varieties of flowering shrubs, are twice the size of the old kind. The flowers of Gerbe de Neige are enormous, fragrant, and so abundant that the branches are bent down by their weight. Another new hybrid is Boule d'Argent, with large double, fragrant flowers; Hybridus Lemoinei erectus has small white flowers. But those of Zeyheri, a good hardy shrub, are scentless.

I hardly ever smell Syringa without recalling an experience of my father's boyhood, which he used to say had been one of his lessons for life. 
As a small boy he was passionately fond of the scent of Syringa; and one day he thrust his head into a bush and drank in the fragrance, till it suddenly turned into a nauseating stench; so that from that moment his horror of it was as great as his former enjoyment; and never, as he would tell us, did he forget that sharp reminder that one might have too much of a good thing.

What is a garden without Laburnum-the "Golden Rain"? And Guelder Roses, how precious they are in the shrubbery, with their pure balls of snow in Spring and their resplendent foliage in Autumn. Viburnum plicatum, the Japanese Snowball, is so handsome a shrub that it ought to be grown as a specimen; while $V$. opulus, with its red berries, and $V$. sterilis, the ordinary Guelder Rose, will quickly run to ten or twelve feet in height, brightening up the sombre evergreens during many months with flower and foliage. Five years ago I planted a group of shrubs some five feet apart in the grass at the corner of the lawn, to break the wind. Half-a-dozen good 


\section{6}

\section{EVERSLEY GARDENS}

Rhododendrons; Phillyrea medea, which I not only love for the sake of one-now a big tree -in the Study garden at the Rectory, but because its foliage recalls that joy unattainable in England, the Olive; Escallonia Macrantha; Berberis Famesonii; Viburnum plicatum; Exocharda grandiflora; three Penzance Sweet-briars; and a pink Weigela, which likes its position so well that it is now a huge bush over seven feet high, and after flowering gloriously in the Spring, sometimes bears a number of flowers through August and September. But a Guelder Rose, with annual shoots of three to five feet, has outstripped all the other shrubs, even the standard scarlet Thorn in the centre, and as I write is a pillar of brilliant crimson foliage. These shrubs were all chosen for hardy constitutions, rapid growth, and a succession of colour effects, which begin early, as the grass below is thickly planted with Crocus and Daffodils, and will I hope go on late when I can add the pale mauve of the Colchicum.

Why do we not grow more Magnolias in our gardens? True, they do not come among 
the possible plants of the perfect shrubberythey are far too precious for that. But how rarely we see $M$. Conspicua, and how superb is the effect of the grand specimen in the Champs Elysées in April, a pyramid of big white stars against the budding green of shrubs and trees. And what can be more exquisite than a bush of $M$. Halleana (stellata) standing on fresh green grass? $M$. grandiflora is of course as common as it is beautiful: but it is seldom grown in England as a tree-its natural form. And although it is too much to hope that in our climate it should ever attain the enormous proportions it reaches in the Southern States, where in the Buenavista Cemetery at Savannah one has seen it growing as huge forest trees sixty feet high, covered at Midsummer with thousands of blooms, yet there is no reason why in sheltered places here it should not flourish as a specimen tree.

Of Spiræas, many, various, and all delightful, what praise can be adequate? I have found certain of them of the utmost value in a new garden; but there are many more 
which I do not (yet?) - possess. A corner shrubbery bed was necessary to produce as quickly as possible both effect and shelter, not only from a malicious draught of wind, but from every one who came to the front door and could espy me at the bottom of the garden whether I was "at home" or not. And in it I planted three Spiræas, with a few strong growing Roses and Rhododendrons: the exquisite $S$. Thunbergii, which, as Mr. Waterer truly wrote me word, "is one of the best of them all, for it is beautiful from the time it puts out its very early flowers right up to nearly Christmas;" the golden-leaved $S$. opulifolia aurea, a handsome and vigorous grower which has to be cut back ruthlessly; and $S$. prunifolia, most engaging of all, with its charming blue-green leaves and clusters of tiny white flowers that make fairy wreaths of each shoot. This was five years ago. The Rhododendrons survive but protest. An Escallonia and shrubby Veronica grow fairly. The Roses struggle gallantly to hold their own, and sometimes succeed; but Lilies and Mont- 
bretias are quite overcome by the triumphant Spiræas-and I have won my shelter.

Now last and best of all, a song of praise in honour of the most enchanting of flowering shrubs, Hydrangea paniculata; for it is impossible to have too many of it in the wild garden, in the front of the shrubbery, as wellkept standards in the flower border, in beds by itself, or mixed with flaming Gladioli or Lobelia Cardinalis. Perfectly hardy, as easy to grow as a willow, all it asks is good soil, plenty of water in Summer, and hard pruning in February; then every shoot will bear its huge panicle of white blossoms till the frosts come; and even then, though the leaves fall, the dry flower heads make an effective point among the evergreen shrubs. In the Garden of Delight it is grown lavishly; and its effect in the Wild and Water Gardens-for it delights in moistureis a thing never to be forgotten : here rising out of a group of choice shrubs and perennials against scarlet and pink and crimson Lobelias - the panicles so heavy on their slender stems, that they have to be tied up to prevent their 
IOO EVERSLEY GARDENS

trailing on the path; there overhanging a Lily pond, and reflected in the still water beyond the blue of Pontederia cordata; while in the broad borders leading down to the Kitchen Garden it is grown in well-trimmed standards, which last year were surrounded by a crimson cloud of Nicotiana Sandera, producing a singularly fine effect. 


\section{CHAPTER VI}

THE SUMMER GARDEN

\section{PERENNIALS AND ANNUALS}

Is the gardens we love best there is always to be found a personal note, the sign and seal of some distinct individuality, which leaves its impress long years after the head that planned, the hand that wrought, the heart that loved, have left it, or mayhap are laid to rest in the nearest churchyard. Who does not know the way in which the scent of certain flowers recalls some such gardens, be they small and humble, or large and magnificent; and how it brings a quick, sharp pang, half pain, half pleasure, in its sudden evocation of the past? For instance, I can never smell the fresh and quaintly aromatic fragrance of the butterfly-like flowers of the Pelargonium, with their honest, friendly faces, 


\section{IO2 EVERSLEY GARDENS}

veined and blotched with rich colouring, without a vision of the hall in a well-beloved house beside the Thames, where many happy days of my girlhood were spent. And a certain combination of Oak-leaf Geranium, Clove Pinks, "Cherry-pie" - the old-fashioned pale grey sort-and sweet-scented Verbena, placed in a wide-mouthed glass, unfailingly conjures up the slippery glazed chintz and muslin-covered cushions of a sofa beside the writing-table, set in a south window looking across the garden to the Channel and the gleam of light on the South Foreland.

The delicious old Warwickshire Garden at Tachbrook I once tended for some twelve years, bore this same individual note. And though I had never known the maker of it, and she had long gone to her rest, while for several years before our tenancy it had been sadly neglected, yet the impress of her care and love still pervaded it. A day seldom passed without a thought of the hand that twenty years before had planted the great Maréchal Niel (from which one Summer I 


\section{THE SUMMER GARDEN IO3}

gathered 360 perfect blossoms) on the south front of the seven-gabled seventeenth-century house, with its panelled rooms, its fine oak staircase, and its thirteen alarming attics reached by three different stairways. Hers was the standard Pactole on the lawn-my first acquaintance with that old and unjustly neglected Tea Rose. Hers the flame-coloured Alstrcemeria psittacina under the study window; and the white Jessamine, and the delightful old pink Rose whose name I never was able to discover, against the wall of the little corner garden. So that when I had the joy of restoring that little corner garden to its original uses, filling it with choice Roses instead of Potatoes, I liked to fancy that her gentle spirit was pleased to see the place she had loved cared for once again. And I should like to think that after I go to my rest, I may leave some such imprint behind me in the garden I have made.

But this personal note is a subtle thing that cannot be learned from books. There is no recipe for making it, such as those for 


\section{IO4 EVERSLEY GARDENS}

rose-water or cheese-soufflé. It can only grow, grow slowly of a great love, of time and thought bestowed unsparingly and constantly. Still less can it be attained by a servile copying of other gardens, however admirable. No true gardener wishes to be, or indeed can be, merely imitative, though he may and ought to be ready to glean hints and suggestions wherever he goes. What suits one place is perhaps absurd in another. Imagine how completely out of place Yews clipped into peacocks or teapots would look in a brand new villa garden, delightful though they are in front of the little old cottage in the village street, or in the stately pleasaunce of some ancient manor-house. "Carpet bedding" again, which is all very well, if used with rare discretion, in the Italian garden of some palace or majestic country-house, becomes an absurdity and abomination in the two or three formal beds in front of the rural cottage or country rectory. It is out of place, and consequently out of taste. While the daylabourer's little straight strip of ground is a 
thing of beauty and delight, with his freegrowing standard Roses, probably budded by himself on Summer evenings, and his processions of Our Lady's white Lilies that flourish with an exasperating vigour and beauty ours never attain, despite all our anxious-perhaps over-anxious-care.

This personal note, whether it be left for those who come after or whether it exists for our own delectation in the present, speaking to us of places and people we like and love, is, in truth, a matter not to be neglected and set aside as of no account. And in every garden, great or small, whether it is worked by half one man or by forty, it is easy to create one pleasant place where at every turn we are reminded of our friends, and of our beggings and borrowings-let us hope not of our pickings and stealings-from their gardens. We may make it each one according to our fancy; and never, oh! never let it be on any set plan.

My Border of Friendship, filled with gifts from far and near, happens to be a long 


\section{I०6 EVERSLEY GARDENS}

straight herbaceous border. And many are the happy memories, the delightful spots, it conjures up in Summer days. That Spirea palmatum came from the lovely Ross-shire garden that stands 300 feet above the Cromarty Firth, with the huge Gean tree overhanging one corner, snowy in Spring, a leafy fortress where blackbirds and thrushes fight in August over the ripe wild Cherries, then turning flame-colour in October against the old grey stone house with its pepper-box turrets that rise above it. Dear garden, with your splashing fountain, your Flame-flower creeping over the low Yew hedge, your marvellous pillars of Crimson Rambler, and your matchless Raspberry bed, in which human blackbirds, be they American millionaires or humble Britishers, spend more time in eating than in gathering the fruit they have been ordered to pick for dessert.

The thriving tufts of St. Bruno's Lily were brought twenty years ago from up above Müren, where the sheets of delicate white flowers so charmed the late venerable and 


\section{THE SUMMER GARDEN 107}

beloved Bishop of Chichester that he left his umbrella against a fence, and the Lilygatherers trotted back a couple of steep miles in the evening to find it. Most of the Michaelmas Daisies and Perennial Sunflowers, that promise so well for the Autumn, arrived in a dog-cart one November day from a delightful Berkshire garden twelve miles away. The old Crimson Cloves, heavy with blossom, and the brilliant little creeping $V$ eronica Rupestris that forms a dense border of blue almost rivalling the colour of Lithospermum prostratum, are souvenirs of a garden dear to us in childhood, where, when we tired of play, we would petition our grandmother for sticks of the twisted barley-sugar she always kept in her sitting-room. The pale blue Delphinium came from an old riverside garden at Chiswick, whose owner is working to help and pacify our brother Boer at Bloemfontein; and the tall purple Aster hard by was a gift from a good cottage neighbour, whose son in our Hampshire Volunteers was also at Bloemfontein a few 
years ago, fighting brother Boer. The Jerusalem Cowslip, the red Pœony, and many another treasure, are gifts from a little walled garden half a mile away where everything grows because everything is loved. While golden Alstrœmerias and fiery Montbretias have travelled hither from the stately precincts of an Archiepiscopal palace, and hold their heads high in consequence. And thus, we walk beside our Border of Friendship in the long July evenings when work is done, weaving garlands of pleasant thoughts and tender memories.

A busy time in all gardens, great or small, is this month of July-the turning-point of the year, when our labours are crowned with their fairest results. Though the beds were filled long ago with bedding plants, and with those charming half-hardy annuals, Asters and Stocks, Zinnias, Salpiglosis, Nemesia, and so forth, that cost so little and add so greatly to their beauty from August to November, they need care. Verbenas and Ivy-leaf Geraniums must be pegged down; and the old-fashioned 


\section{THE SUMMER GARDEN}

IO9

wooden peg cut from the bavin of pea-sticks is still, to my thinking, superior to the wire pin of modern days. Carnations also must be tied up neatly, or half their value will be lost in the next six weeks; and as soon as their "grass" is ripe enough, the back-breaking work of layering must begin. It is well to look out even among that delightful and useful race the Marguerite Carnation, which is treated as an annual or biennial, for a sport or throwback that is worth propagating in this way. I chanced some five years ago to get such a plant among a dozen seedlings; and by layering every shoot I secured a good stock of what has proved to be a true and most valuable Carnation, bearing sheaves of peculiarly lovely flame-pink flowers on long stalks in great abundance. The old Crimson Clove grows better in my garden from cuttings than from layers : but this is probably a mere local exception. The admirable yellow-self, Germania, layers with great ease; and its strong constitution makes it most valuable in the herbaceous border, where a line of Carnations of many sorts 
forms a charming finish along the front: but its tall flower-stalks must be staked early, or it soon looks untidy.

The said herbaceous border needs constant and watchful care just now. It is so easy, by even a week's neglect, to let it turn into a wilderness. The Oriental Poppies, for instance, are most unsightly as soon as their flowers are over, and must be cut down at once to give room to the Alstrœmerias, Montbretias, Gladioli, Tiger Lilies, and Lobelia Cardinalis, which have been planted among them to ensure a succession of red and orange through the Autumn. The rather tiresome blue Lupins-tiresome because they are so very forthcoming and apt to appropriate the whole border-may go too, as far as their flower spikes are concerned, for their foliage is not to be despised. And any Delphiniums not required for seed should be cut down as soon as possible, when they will repay us with a few welcome flowers in the Autumn. It is easy to get a good stock of these beautiful plants by sowing the seed in drills in the open 


\section{THE SUMMER GARDEN}

ground the moment it is ripe this month, and pricking the seedlings out in store beds or in their final position as soon as they can be handled. A few will flower the next year; but they will come to perfection the year after. In a neighbouring garden, long rows of these hybrid Delphiniums of every shade from palest azure to deepest gentian blue, produce an indescribably charming effect along a shady terrace. And their owner assures me they have all been raised in this way-a few heads of the choicest flowers being marked every Summer for seed, which is sown as soon as it ripens.

The seed also of the hybrid Aquilegias should also be gathered the moment it is ripe; for one cannot have too many of the fine longspurred varieties, so remarkable in size and colour. But none of these modern hybrids surpass the beauty of their parents, $A$. carulea and $A$. chrysantha. Never shall I forget my first sight of a bed of $A$. carulea at the edge of the pine forest upon a pass of 8100 feet in the Rocky Mountains. Though panting with 
mountain sickness, all miseries were forgotten as I fairly fell on my knees before the wondrous flowers. They were of immense size-a good two and a half inches across, and shone out under the shade of Pinus ponderosa like pale blue stars.

Of course Dahlias, Chrysanthemums, and the many forms of Helianthus, Michaelmas Daisy, \&c., must be staked and tied-but not too tightly, the great mistake of the unthinking gardener - as soon as they are eighteen inches high. And Phloxes, so splendid in rich variety of colour, not only need tying lightly, but copious waterings in dry, hot weather, or the brilliant flowers burn and shrivel. Verily, it is as necessary with the plant as with the child, to follow Solomon's advice and train it up in the way it should go, thereby saving many marred and broken shoots later on. Even my beloved Pœonies from Chenonceaux need a good bit of tarred string, or that excellent invention, Raffia Tape, to keep the shoots together before their glorious heads of white, pink, and crimson blossoms weigh them down to the 
earth. Though they have been out of flower for a month, their noble foliage is a delight all through the Summer and Autumn. The various Campanulas also want watching, for half their effect is lost if they are staked after their flower shoots have begun to sprawl and ramble over the border. Speaking of Campanulas reminds me of that excellent biennial, C. medium, the once familiar Canterbury Bell, now so strangely neglected in many gardens. A quantity of these flowers raised one year from a small packet of Sutton's seed, and planted alternately with some particularly fine Sweet Williams, went far to reconcile me to a narrow and usually rather dull border under a Rose hedge; for they made it gay with colour for weeks-pure white, pale pink, mauve, and blue, both double and single. The modern forms of this flower are so handsome, so easy to grow, and seed themselves so freely, that I wonder they are not more generally cultivated; and, as with C. Persicifolia, if one has patience to pull off the faded flowers others come out in their place and prolong the flowering season 


\section{4 EVERSLEY GARDENS}

for many weeks. I shall never forget the effect of a mass of them near Stratford-on-Avon, when years ago, with two well-known artists and a distinguished novelist, we made pilgrimage round the little villages of the Shakespearean Rhyme. If we had been entranced with the Roses of "Piping Pebworth," so did we all exclaim with delight over the Canterbury Bells of "Beggarly Broom," which filled the tiny garden in front of a labourer's little old cottage.

But what would the Summer Garden be without its Annuals? Rightly used, annuals are a never-ending delight. Wrongly used, however, they begin as an untidy mess, and end as a desolate waste. How often do we hear people say, "Annuals are such useful things, they will grow anywhere, and you need take no trouble about them." So they are sown without any intention as to colour effect, any thought as to suitable position-sown too in thick patches or rings, a hundred seeds being used where ten would suffice. And when the poor things, never thinned out and seldom 


\section{THE SUMMER GARDEN}

watered, do attempt to grow, seedsmen, gardeners, or weather are blamed, because the crowded starvelings cannot be compared with a neighbour's fine display. But when one sees the superb effects produced by many of the hardy, as well as half-hardy, annuals grown under proper conditions-namely, with care, knowledge, and taste-and so disposed that when their short season is over something else is ready to fill their place in the border, then indeed one eagerly ponders how best to paint one's garden with such glorious tints from Nature's colour-box.

- I well remember the advent of the exquisite Shirley Poppy years ago. I first sowed them in the old Warwickshire garden at Tachbrook; and how they revelled in that strong soil may be seen in Miss Whitehead's charming picture of the gateway into the walled garden. Here they were the first annuals I sowed when my borders were far from being as well filled as they are now. I have never had to sow them again, for the lovely flowers seed themselves and come up year after year in undiminished 


\section{6 EVERSLEY GARDENS}

beauty, if only the weakly ones are pulled up at once and any field Poppy instantly destroyed. Godetias are, of course, one of the most valuable of hardy annuals. But gorgeous as are Scarlet Queen, Crimson King, Bridesmaid, Satin Rose, \&c., I was moved to enthusiasm when I first saw Sutton's Double Rose, a complete novelty to me. In growth it is like a glorified Clarkia, two feet high, with long sprays of exquisite double pale pink and carmine flowers. It is evidently a distinct species, which, I believe, was in cultivation forty or fifty years ago, but only resuscitated lately by Messrs. Sutton - probably one of those mentioned by Mrs. Loudon in the I 844 edition of the "Ladies' Companion to the Flower Garden," as introduced from California in I835. I see she gives the same advice as do modern authorities-namely, that to grow Godetias successfully they should be sown in September.

Another treasure to the Summer Garden is the Annual Chrysanthemum, so hardy and decorative in all its many varieties, double and 


\section{THE SUMMER GARDEN}

single. Coronarium and Carinatum last on till after quite sharp frosts; while the great single sulphur-coloured flowers of Morning Star rival the finest yellow Paris Daisies.

The beauty and value of annuals is specially borne in on my mind, when a missive from my friend $\mathrm{Mr}$. Leonard Sutton, warns me that they are in their July glory at Reading -spread in those sheets of colour that every traveller by the Great Western Railway must know. And after an afternoon spent among them I come home dreaming of great planstoo of ten never carried out-for the next year. Some, however, do come to fruition.

All annual Larkspurs are valuable. But there is one whose praises I never tire of singing ${ }^{1}$-Sutton's Rosy-Scarlet Stock-flowered Larkspur. For it is that warm shade of pink with yellow for its basis which is described as salmon or flame-a colour that gives me most peculiar and exquisite delight whether I find it in textile, in flower, or in sunset sky. Therefore I greatly rejoice when I see

${ }^{1}$ See "The Autumn Garden," p. 230. 


\section{I 8}

\section{EVERSLEY GARDENS}

an effort to develop its many gradations in horticulture. And in many flowers it now appears, the result of infinite scientific selection. The Sweet William Pink Beauty took twenty years of patient work to develop. In Primulas, Cyclamens, and even in Cinerarias it is gradually replacing the detestable magenta shades. In Stocks we find it in Sunrise, and others both of English, French, and German origin. In Antirrhinums-those faithful biennials-Rosy Morn, Carmine Pink, and Coral Queen show it. And when we turn to Verbenas, now so happily established as bedding plants which can be grown as annuals, the superb Miss Willmott is of surpassing beauty.

To Messrs. Sutton the Summer Garden owes a large debt among other delights for Nemesia strumosa Suttoni, introduced by them from South Africa in 1888-an annual whose extraordinary colours and easy cultivation make it a treasure to every gardener. Another valuable introduction of the last three years are the new Nicotianas. N. Sandere was 
first exhibited in 1904 by Messrs. Sander of St. Albans; and the sensation it created at the Holland House show will not soon be forgotten. Then came the various coloured Hybrids of $N$. Affinis, raised by MM. VilmorinAndrieux and others, which, besides possessing strange and beautiful colouring, have the merit of being as sweet-scented as their white parent. I am curious to see whether they will reproduce themselves by root shoots as $N$. Affinis does. Certainly they contrive to stand a fair amount of frost; for a plant of $N$. Sandere stuck into a dry south-east corner by my back door, was in full flower this Winter till the heavy frost of Christmas week, the earlier frosts having left it untouched.

But the climax of annuals is reached in Sweet Peas; and how can I praise them adequately?

As the first splendours of Roses wane, Sweet Peas are a sufficient consolation in the few weeks that must elapse before the Rose beds are once more full of bloom. Never have they been 
finer with me than in the blazing heat of last Summer (1906). Looking out of my north windows, the long rows from which I had been cutting ceaselessly since mid-June were a solid mass of colour in late August. And great was the astonishment of a tall youth who brought me a note from the far end of the parish while I was hard at work cutting fifty dozen for market, to find that they out-topped his head by 20 inches-a good 7 feet 8 inches in all. As many were from my own harvesting of the former year's crop, I may be forgiven a little conceit over them.

While I remain faithful to some of my old favourites, Celestial, Oriental, Blanche Ferry, Gorgeous, and Salopian, many of the newer sorts stand pre-eminent in size and beauty. And first of all, in abundance, size, and delicate loveliness, I place the pink Gladys Unwin, with its charmingly waved wings and standard. Of this I was particularly proud, as the whole stock came from six plants out of a tiny packet of seeds which my friend Mr. F. A. Roscoe, of the Golden Orchard, 
Steeple Morden, kindly sent me to try in 1905. Every one of my own seeds came true, and nearly every stem, from 12 to 18 inches in length, bore four flowers. Miss Willmott was equally fine; and my old favourite Oriental nearly as good.

Countess Spencer-if one can get the true stock, for the ordinary stock is more sport than true-Prima Donna, Florence Spencer, Bolton's Pink, Fanet Scott, and Agnes Eckford are my other pinks for this year; with the fine rosy-carmine $\mathcal{F}$ hn Ingman, and $E$. $\mathcal{F}$. Castle (1907). Scarlet Gem, which otherwise did well, suffered a little last Summer from the intense sun which always causes it to burn. But Eckford's new Queen Alexandra, while possessing all the merits of Scarlet Gem in colour, size, and habit, is happily sunproof, and an even finer flower. For crimson, though I am faithful to a row of my old friend Salopian, for a main crop nothing equals the grand King Edward VII., one of the finest of all the novelties of the last three years from Wem; and here it was indeed magnificent. 
The orange of Henry Eckford which created such a sensation in 1905 , being a completely new break in colour, is so violent that it ought to be planted with care, so that it does not swear with the other Sweet Peas, Black Michael being about the only one able to keep it quiet. But Evelyn Byatt and Helen Lewis, though intense in colour, are more manageable as to companions. For lavender and mauve, Lady Grisel Hamilton, Mrs. G. Higginson (syn. Gladys Deal), Miss H. C. Philbrick, New Countess, Mrs. Walter Wright, Helen Pierce, and the beautiful new Frank Dolby (I907) are all most valuable. The unsurpassed Dorothy Eckford for white; Hon. Mrs. Kenyon and Mrs. Collier (1907), primrose; and Dainty, white with pink picotee edge, are my palest quartet; my darkest being Black Knight, which I prefer to Black Michael, and the new Horace Wright (1907) for deepest violet. A row of Coccinea, the cerise self, unique and absolutely distinct in colour, foliage, and growth, should always stand a little apart, for it is not as tall as the modern 
giants, though mine grew 5 feet high last Summer. It is invaluable for table decoration, as its pure colour is, if possible, even more brilliant under artificial light, blending delightfully with the stiff bluish green foliage and haulms, and lasting well in water.

The secret of success in Sweet Peas in my own garden, and in the little Flower Farm I started with a neighbour last year, has been due simply to treatment. The soil in which they are grown is a good loam. It is thoroughly trenched and manured, and left rough for two or three months to mellow. The seeds are sown 3 to 6 inches apart (and thinned later) in blocks of colour 5 feet long, the trenches being 5 inches deep and 8 wide; and the moment the flowers begin to show, liquid manure-not too strong - is given freely once a fortnight, and copious waterings once a week. The flowers are, of course, picked early in the morning as soon as they open; and if they have to be sent away are put into water immediately and kept in a cool darkened place till they are 


\section{I24 EVERSLEY GARDENS}

packed. By never allowing a blossom to go to seed, the flowering of Sweet Peas may be prolonged for more than three months. Planting far apart is another help. Some growers advocate 18 inches between the plants; and for exhibition flowers this may be advisable. But it is somewhat a counsel of perfection; and for market and home use I find 6 inches answers perfectly. Indeed, if I had exhibited last year, I am assured that I should have swept the district of prizes. Above all, Sweet Peas must never be sown two years in succession on the same spot; and it is better, if possible, to sow once in three years on ground that has been deeply dug, well manured, and allowed to lie rough and sweeten with the Winter's frost. 


\section{CHAPTER VII}

THE ROSE GARDEN

\section{TEA AND HYBRID TEA ROSES}

IT is curious to look back on one's childhood and recall the awe with which Tea Roses were regarded-things too delicate and precious for any place but the conservatory. There was a legend, so oft-repeated that it had come, like some other legends, to be considered an established and authentic fact, that none of the race could withstand the English Winter. And indeed, if any one was reckless enough to plant a Tea Rose out of doors, it was nearly sure to die. For the poor thing, after being pruned in October, was so smothered in straw, so coddled up in matting, that it had no chance to breathe; and its owner was annoyed and distressed at its early death, and all his neighbours said, "We told you so:" the legend 


\section{I26 EVERSLEY GARDENS}

consequently being more devoutly believed in than ever. What would the amateurs of the late 'fifties say to our cheerful plantings nowadays, with a good mulch in October, a few bits of bracken drawn through the branches in December, and no pruning till April.

One of the wonders and delights of my childhood was a fine plant of Souvenir d'un Ami - the beautiful salmon-pink Tea Rose brought out ten years before, in 1846 , by Defougèrewhich grew up a pillar in the conservatory at Fir Grove near by. And when once the dear owners bestowed one of its flowers upon me, I think there was not a happier little girl in all Hampshire. For sake's sake I determined it should be the first Tea Rose I planted when I made my garden here, though the old legend still hung in some cobwebby recess at the back of my mind, making me feel, in spite of contrary experience, that I too was perhaps being hideously reckless, if not positively immoral. However, I put my Rose into the border with a certain amount of fear and trembling, and could hardly believe my eyes when it laid hold 


\section{THE ROSE GARDEN}

lustily. It never gets any special attention; for it is in the long border under the hedge, facing north. But each year its great bellshaped fragrant flowers on their long slender stems show grandly against the Rhododendrons about it, and go far to disprove the delicacy of Tea Roses.

The original "Blush Tea-scented Rose" was brought from China in 1810 . In 1824 the "Yellow China or Tea Rose" was introduced from China by Mr. Parkes. And the French growers at once began raising seedlings from these two fruitful parents, as both in France and Italy the Yellow Tea Rose seeded freely. The earliest of these "Tea Roses" which still hold their own among the host of their brilliant successors, is (most appropriately) Adam, raised in I833; Pactole; Devoniensis, I 833; Safrano, I 839 ; Mme. Willermoz, I 843 ; Niphetos, I 844 ; Souvenir d'un Ami, I846; Mme. Bravy, r 848 . And in 1853 , Jacotot's Gloire de Dijon made a complete revolution in the race-the strong, hardy, and prolific parent of a new type of Tea Roses. I cannot but think, however, that so 
distinct a break in flower, foliage, habit, and substance from the original type, must have been due to the introduction of some other strain-such as the Noisette-in the fertilization of the seed-bearing plant that produced Gloire de Dijon.

Since that date new Tea Roses have been raised ad infinitum both in France, England, and Luxembourg; while of late Germany and the United States have contributed some fine varieties to the bewildering list. Only to mention a few of the many who have devoted themselves to the raising of Tea Roses in the last fifty years, and more recently of the Hybrid Teas, the names of Messrs. William Paul and Son of Waltham Cross, Ben Cant of Colchester, Paul of Cheshunt, Prince of Oxford, Alex. Dickson of Newtownards, among British growers; and the famous French houses of Ducher, Nabonnand, Pernet, Guillot, Bernaix, Bonnaire, Levet, Lacharme, Soupert et Notting, are household words to all Rose-growers.

Many of these lovely Roses very distinctly show the effect of the old Yellow Tea Rose 


\section{THE ROSE GARDEN}

upon the race, in the golden and sulphur base which adds such richness of tone to their countless shades of white, pink, crimson and copper. My own experience has been that for the Autumn garden, Tea Roses are absolutely essential; for of all the beloved family none flower better till "Winter's rains and ruins" stop all blossoms. On a November day last Autumn, despite the torrents that had been falling for forty-eight hours, a little bed of General Schablikine was bright with half-open buds; the invaluable G. Nabonnand had good flowers upon it; Tillier looked as if its sturdy flowers would go on till Christmas; and Marie van Houtte was simply smothered in healthy buds that only waited for a dry and sunny day to come into full beauty. I would almost place this delightful Rose first on my list for its amazingly prolific qualities, being constantly in bloom. One year a three-year-old bush here displayed sixty-two well-shaped blossoms in the middle of October. But though one classes Marie van Houtte among the yellow and white Roses, it is a mistake to plant her among them 


\section{I30 EVERSLEY GARDENS}

if we desire to keep to one colour in the bed. I did this eighteen months ago-putting four large plants in the centre with white and palest lemon. And 1o! the intense sun of last Summer did for Hampshire what, I am told, always happens in New South Wales; and Marie blushed violently pink. The disastrous effect may readily be imagined; and the dear creature is now lifted and planted where she can do no harm and only give delight, her place being taken by Augustine Guinoisseau, the white La France.

Without making a list many pages in length it is impossible to mention all the desirable and hardy Tea Roses that we may grow in our borders. So I will confine myself to a few of my special favourites-some of which are not as well known as they should be in English gardens. Among the pale fawn, yellow, and white shades, the fine White Maman Cochet is an excellent Autumn Rose; and so is the grand apricot-yellow Souvenir de Pierre Notting: but this last and Enchantress, another lovely Rose, should be grown as standards to enjoy the full beauty of their drooping blossoms. Safrano, 


\section{THE ROSE GARDEN}

welcome as it is, even though tired by its long journey from the south of France when on a February day one buys it in the London street, is far more delightful in the garden, as it never ceases blooming till the frosts; and I find it a much stronger and more solid Rose in the open than under glass. Coquette de Lyon-one of the parents it is said of Kaiserin Augusta Victoriasent me from France four or five years ago, and for which I search English catalogues in vain, ought to be in every collection. It is very dwarf, carrying its heads of neat, full, mediumsized flowers, which are white with a bright sulphur centre, on sturdy upright stems; and, as it is always in bloom and lasts well in water, it is invaluable for cutting. Peace, one of the newer Roses, is another that should be largely cultivated for its creamy-white flowers, borne singly on strong erect stems; and, as becomes a sport from the invaluable G. Nabonnand, it flowers freely and late into the Autumn.

Among the endless variety of peach, pink, and red Tea Roses, three which, strange to say, are apparently little known in England, are 
great favourites of mine. Amabilis, a clear China-pink, and most abundant bloomer, was sent me by a happy mistake from Orleans some years ago, and has delighted all beholders since. So has Baronne de Hoffmann, which one only finds in one or two English catalogues, a vivid copper-red with yellow base to the petals, extremely vigorous in growth. But why is not that beautiful Rose, Monsieur Tillier, raised in $189 \mathrm{I}$ by Bernaix of Lyons, seen oftener here? It is not a show Rose: but then we are not all of us exhibitors; and it is simply invaluable for cutting, never out of flower from June to November, and bearing heads of medium-sized, imbricated carmine and brickred flowers in such abundance, that a group of two or three plants makes a vivid splash of colour right across my garden. I first saw it at the Paris Exhibition of 1900, and have planted it freely ever since with great success, as it is quite hardy and even more effective than a China Rose, and lasts for many days in water.

As to red Tea Roses we have travelled on far 
and fast since I first saw Madame Lambard at the Paris Exhibition of 1878 . It had appeared the year before, and was described as the "finest deep-red Tea Rose in cultivation." I shall not soon forget the excitement she created. Doubtless her colour in France is deeper than in England; for even here one sees the difference sun and warmth make to her, the first blooms in July being much darker in colour than the charming, rather pale blossoms I see from the window on an early October day. Few Teas, whether old or new, surpass her; strong, hardy, always in flower, she is hard to beat. But of course for deep vivid colour she cannot now compare with some of her modern rivals, such as Betty Berkeley; for among them we find some amazing tints. With the exception of $M a$ Capucine, nearly all the deepest and most brilliantly coloured Tea Roses have been raised since Madame Lambard made her welcome appearance thirty years ago. And few are more effective for massing than General Schablikine. Its abundant flowers, a bright coppery-red, are never wanting throughout 
the season-I cut a handful on November II, last Autumn-and with its good foliage made it admirable in a group. Beauté Inconstante, true to its name in both particulars-for beautiful it is, and one of the most variable of roses-is only exceeded in its vagaries by Souvenir de Wm. Robinson. This last, when it conducts itself properly, is a quaint and pretty little Rose, with its strange mixture of " pœonypink, salmon, cream-white and apricot with violet veins," to quote the description by its raiser, M. Bernaix. But how seldom is its conduct satisfactory; for it is a weak grower, and its variations, even on the same plant, make it more curious than beautiful. Far more precious are that grand pair Souvenir de Catherine Guillot, and Souvenir de F. B. Guillot; the nasturtium, carmine and orange of the first, the deeper shades of nasturtium-red and crimson of the second, are startling in intensity; and a handful of their long pointed buds and halfopen flowers in October are a joy not easily forgotten.

The beautiful Mrs. B. R. Cant (I90I) Rose, 


\section{THE ROSE GARDEN I 35}

with silvery inner petals suffused with buff, is worthy of a place in the front rank of the many pink and salmon Tea Roses; though, as I have said, few can excel the lovely old Souvenir d'un Ami. Catherine Mermet is the beautiful mother of many children: and chief of her descendants is Bridesmaid, the well-known Rose of which such thousands are forced in early spring for Covent Garden. Of a deeper pink and sturdier growth, this Rose has almost superseded its parent for market. Maid of Honour, a deep rosy pink, is another sport from Catherine Mermet, and so is the grand Exhibition Rose, Muriel Grahame. Maman Cochet, a fine show Rose, is also as good a border Rose as one can find. It was in flower here last year from June to mid-October, its enormous blossoms the admiration of all who saw it. Mrs. Edward Mawley, another fine salmon pink, is more effective as a standard than as a dwarf, owing to its drooping habit of growth. And Madame de Watteville has never been wholly satisfactory with me: but where the buds have been well thinned, as in the "Expert's" Thames Valley 


\section{I36 EVERSLEY GARDENS}

garden, I by no means despise a bunch of its lovely blossoms on long stalks. These Tea Roses are but a tithe of those I grow and delight in. I have, however, kept two of my greatest favourites till the last. They are certainly among the very best for bedding; and one, the delightful Dr. Grill, is not as universally cultivated as it should be. Perfect in shape, prolific in flowers of a delicious mixture of pale copper shaded with tender pink and China-rose, it is deliciously fragrant and lasts well in water. While even more perfect is G. Nabonnand, pale rose shaded with yellow. For a bed-such as the one at Kew last year-a mass of this Rose cannot be surpassed; as its handsome, largepetalled flowers and singularly beautiful buds are produced in quantities the whole season, and its full foliage and bright reddish shoots are in themselves most decorative.

HybRID TEAs.-A statement I saw some time ago in a gardening paper made me a little sad. It was a letter from a head-gardener, who said-I cannot remember the exact wordsthat the improvement of late years in Tea and 
Hybrid Tea Roses had been so great that he was planting nothing else, and was doing away entirely with all Hybrid Perpetuals. Now this is one of those wholesale and wanton followings of fashion that, I confess, exasperate me not a little. Why discard one beautiful thing because another is as, or even more, beautiful ? Why turn our backs on the old and faithful friend, because forsooth the new acquaintance pleases us? Are our hearts so small and mean that we have not room in them for more than one liking at a time? Moreover in all things the slavish following of a fashion because it is a fashion, whatever its intrinsic merits, is odious and unworthy, reducing sentient human beings to the level of a flock of sheep hurrying blindly and foolishly through a gap. And when about three years ago some one suggested to me that it was a good idea to write these humble notes "because gardening is all the fashion," I fear I replied with some asperity, "I write them because I care for my garden, and want other people to care for theirs."

I am sick of that word "fashion;" and now, 


\section{38 EVERSLEY GARDENS}

that it should be imported into our gardens, into the culture of God's loveliest gifts to poor man, into the purest, sweetest, most sane and wholesome of recreations, is indeed too much. But so it is, alas! and we hear on all sides, from morning till night, not that Hybrid Teas are beautiful, but that they "are all the fashion"; not that Sweet Peas are enchanting, but that they are "the fashionable flower," to which everything else must be sacrificed; and that Geraniums are completely superseded by "the fashionable Begonia." I would as soon drown one of my homely tabby cats because it was not a pale lavender Persian, as destroy my Hybrid Perpetuals because they were not Tea Roses; and though I should be charmed to possess a lavender Persian as well as the humble tabby, I can thoroughly appreciate the delights and merits of the very newest Tea Rose without abating one jot of my love for Ulrich Brunner, Duke of Edinburgh, Mrs. Fohn Laing, Mrs. Harry Turner, the dear old General Jacqueminot, or the new and superb Frau Karl Druschki. For without blindly following the fashion of the 


\section{THE ROSE GARDEN}

moment, it is singularly foolish to despise what is new, if at the same time it is worthy of admiration.

Entirely apart, however, from any question of fashion, it is undeniable that in no branch of horticulture have such amazing strides been made during the last few years as in the variety, beauty, and hardiness of the Tea and Hybrid Tea Roses. As I turn to a classic that lies open before me, a precious old copy of Rivers' " Rose Guide," full of my father's notes made long before I was born, and compare its list of Tea Roses with a handful picked in my own garden half-an-hour ago, I cannot but wish that $\mathrm{Mr}$. Rivers, and Victor Verdier and his old uncle Monsieur Jacques of Neuilly could revisit the earth for an hour, and see to what results their faithful patient work in the early part of the nineteenth century has led. Pactole, with its delicate and deliciously fragrant pointed buds, for which we look in vain save in a very few catalogues, is one of the choicest treasures in Rivers' list; and Devoniensis, beautiful now as then, is the only other survivor of some fifteen 
more whose names are actually unknown today.

The race of Hybrid Teas, seedlings from the true Tea Rose, $R$. Indica odorata, crossed with the hardy Hybrid Perpetual Rose, did not then exist. And indeed until the 'eighties we find the Hybrid Tea looked on as a rarity-La France, Captain Christy, and Reine Marie Henriette more or less representing the family. Among this race, to which each year adds fresh beauties, I have so many favourites that it is difficult to make a moderate selection of the best, as far as my own experience goes. But, among the very first, I should place four as being distinct in type and colour, and of superlative beauty. First comes the semi-climbing Gruss an Teplitz, one of the only true crimson-scarlets of the tribe. Its clusters of well-shaped flowers and pointed buds borne at the end of long shoots, its luxuriant green foliage edged with red, its abundance of bloom and delicious fragrance, make it one of the most valuable roses of the last ten years. With me it has done better 
against a west wall than as a dwarf; but I am now also growing it as a single bush, having seen its splendid effect in this form in the garden at Arborfield Hall last year, where a plant, four or five feet high and as many through, was a sheet of bloom last September. From June to November it is always in flower here; and when the window below which it grows is thrown open, the whole room is filled with its scent. Next in order I should place the noble light orange Madame Ravary. Vigorous in growth and in perpetual bloom, its colour varies from rich orange-fawn deeper in the centre, to salmon-white after it opens. The pink Killarney, in colour resembling the inside of some of those tender pink shells of tropic seas, with long pointed buds, large and rather loose flowers, and handsome brown shoots, is an admirable contrast to Madame Ravary. It is extremely hardy; and besides many specimens of it in my Rose beds, one among some choice shrubs has grown in four years into a tall bush, its pink flowers showing up delightfully against the blue-green foliage of Spirea 


\section{I42 EVERSLEY GARDENS}

prunifolia and the white heads of Hydrangea paniculata. For the fourth of the charming quartet I would choose Madame Abel Chatenay, for she is hard to beat. The abundant, well-shaped blossoms, with reflexed petals, pale pink at the edge, shading down to warm clear pink just touched with salmon, are carried admirably on vigorous, upright shoots, and last long in water; while no matter what the season may be, one may always find a few to gather from June to November.

Yet, after all, it seems invidious to make any such selection, when so many others of the race are just as beautiful, hardy, and prolific. Of the clear pink Caroline Testout what praise can be thought excessive! and who that has ever come suddenly on those two wide borders on either side of the broad green walk to the north of Holland House, can forget their effect, planted with hundreds upon hundreds of this lovely Rose in full bloom? A sheaf of Madonna Lilies at intervals did not break, but only accentuated the exquisite band of pure colour, backed by a Rose trellis and a few speci- 
men Hollies. And this shining pink vista carried the enchanted eye on to the sombre mass of the northern façade of the great house, with its curious mixture of Dutch step-gables and Jacobean windows, and its wealth of memories, political and intellectual. On closely examining these surprising specimens of Caroline Testout, they disproved once for all the fallacy that to make Roses grow in London they must be renewed every two years at least; for I found they were old-established plants, which had been pegged down so as completely to cover the ground, and that they were throwing up strong flowering shoots from every joint. Whether as a dwarf or as a standard, Caroline Testout is indeed a treasure.

Among the China-pinks, Madame Fules Grolez easily takes first rank as a bedding Rose which cannot be too highly praised for colour and persistent blooming. But the lovely Belle Siebrecht, better known in England as Mrs. $W$. 7. Grant, and largely grown under glass for the London market, runs her very close, for it is hard to choose between such beauties; while 
the fine Grand Duc Adolfe de Luxembourg, clear pink with a deep rose reverse to each petal, completes a truly lovely trio.

Few Roses, perhaps, have created a greater sensation than did La France in 1867, raised by Guillot. And a noble Rose it is, though the slight lilac tinge in its pink petals detracts-to my mind at least-from its perfect beauty. But this is what my French friends would call "chercher la petite bête," an ungrateful criticism; and I confess to a little mania for pure pink, such as that of Caroline Testout. By a wise decision of the National Rose Society, La France and all its allied varieties, together with Lady Mary FitzWilliam and the invaluable Captain Christy, are now placed among the Hybrid Teas, to which race, by reason of the substance of their petals, their foliage, and their wood, they have always to me appeared to belong.

With Captain Christy, which followed La France in 1873 , I can find no fault as to colour, shape, foliage, or anything else, save that I cannot have enough of his fglorious 
blossoms set in the midst of their strong, handsome leaves, as if each one intended to be placed in a glass alone, and had grown with that intention from the moment its bud was first formed behind the leaf-stalk in the previous Autumn. But even more delightful, because more vigorous and abundant in blossoms, is the Climbing sport of Captain Christy. With me it certainly does better than its dwarf original; and nothing could exceed the perfection of its blossoms outside a south window on a day in early June; while as I write these words on almost the last day of October, a great six-inch flower as well as many half-open buds look in at that same window on the Chrysanthemums that fill the vases within. In a neighbour's sheltered garden a much older plant than mine climbs over a wide wooden arch, and when in full bloom it is worth a journey to behold its huge blossoms, borne so freely on long stalks, and set off by the singularly fine foliage.

Among my favourites in white; lemon, and blush Hybrid Teas, Kaiserin Augusta Victoria 


\section{I46 EVERSLEY GARDENS}

is one of the best, while Alice Furon, Souvenir du Président Carnot, Mme. Pernet Ducher, Augustine Guinoisseau or the white La France, Lady Mary FitzWilliam, and Viscountess Folkestone, are all excellent; and I am looking forward with extreme interest to two plants of the "lemon chrome and golden yellow" novelty of 1906, Mrs. Peter Blair, which were sent me as a birthday present.

Besides those I have already mentioned, other pink, peach, and salmon among my favourites are Grace Darling, Antoine Rivoire, Prince de Bulgarie, Madame Cadeau Ramey, Earl of Warwick, Dean Hole, and the superb new Betty; while in rose and crimson, I rejoice in Lady Battersea, a really grand Rose, Lady Wenlock, the invaluable Marquise de Salisbury, Marquise Litta, and Liberty.

Some of the semi-double Roses of this class are extremely decorative; and of two I am specially fond, the pale lemon Gustave Régis, and the vivid crimson Bardou Fob, whose nearly single flowers are blotched with maroon so dark as to be almost black. Another very 
beautiful semi-double is Lady Waterlow, its clear salmon-pink petals edged with crimson; and when gathered in large bunches its effect is most striking.

Messrs. Alex. Dickson \& Sons, of Newtonards, have recently introduced a number of very interesting single Hybrid Teas, beginning with Irish Beauty, Irish Glory, and Irish Modesty, in I900; the singularly brilliant Irish Star, Irish Brightness, Irish Fride, in I903; followed by the dazzling scarlet Irish Engineer, Irish Harmony, and Irish Elegance, in I904-5. In foliage, growth, fragrance, and peculiar brilliancy of colour, this new race of Roses is a valuable acquisition to the garden. They are all free-growing, of branching habit, and admirably suited for cultivation as isolated bushes; for they attain a considerable size very quickly, and are covered with flowers till the frosts cut them.

In the last two years I have planted all my dwarf Tea and Hybrid Tea Roses in a set of six small and six large beds 5 feet wide, arranged, as far as possible, according to colour. For 


\section{48 EVERSLEY GARDENS}

this, I feel persuaded, is far the best and most effective way of growing them. The small beds each contain five plants of one variety. Caroline Testout and Madame Abel Chatenay are the first pair; Papa Gontier and General Schablikine, the second; Madame Lambard and Killarney, the third. Alternate with these come the large beds containing fourteen plants each: but here I have been obliged to mix the many varieties, keeping as far as possible to those that will shade well into each other. The first pair are both pink. Of the next pair one is white, the other yellow. The third are all shades of red, China-red, and nasturtium; Marquise de Salisbury, Liberty, and the marvellous Guillot pair of Teas being plentifully used. And when I look upon the wonderful diversity of colour and form, and the endless varieties of these lovely Roses that give me such delight from June to November, I can only regret that the amateurs of forty to fifty years ago were deprived of endless enjoyment, by believing the legend of their delicacy. 


\section{CHAPTER VIII}

THE ROSE GARDEN-(continued)

CLIMBING ROSES AND HYBRID PERPETUALS

Despite the excesses of Spring weather to which we poor islanders are subject, what a miracle the opening weeks of the Rose season bring year by year! Even if we have suffered, as we too often do, the varied rigours of frost, drought, rain, and wind in April and May, by the end of June all is forgotten in the glory of our Climbing Roses.

If Solomon said that "of making many books there is no end," surely the same may be said of Climbing Roses; for when will their multiplication ever cease? Yet do we wish it to cease? I, for one, love them too well not to desire more, and yet more, and again more. New or old, Summer-flowering or perpetual, Tea, Noisette, Rambler, Ayrshire, 


\section{I5O EVERSLEY GARDENS}

Cherokee or Bramble-leaved from North America, Wichuraiana from Japan, Sinica from Tartary, Brunonis from the Himalayas, or the last new Hybrid at the Temple Show, all are thrice welcome wherever wall, bank, fence, arch, pillar, dead or living tree can be found for them; or a space on the lawn to plant Pink Roamer, or the Lion, or a dozen others equally free-growing and beautiful, to spread into a huge mass at their own sweet wills.

In my own garden by the middle of June the whole west wall of the house is a sheet of blossom. First among the Roses, the lovely and fragrant old Noisette, Faune Desprez, which used to cover one bay of the Rectory, has in these few years spread over a space I 8 by 20 feet and more, with its light green, graceful foliage and great clusters of sweetscented flowers, bearing as many as seventy blossoms sometimes at the end of one shoot. On one side Gloire de Dijon in equal beauty mingles with it round my window, joining hands below with the vivid scarlet of Gruss 


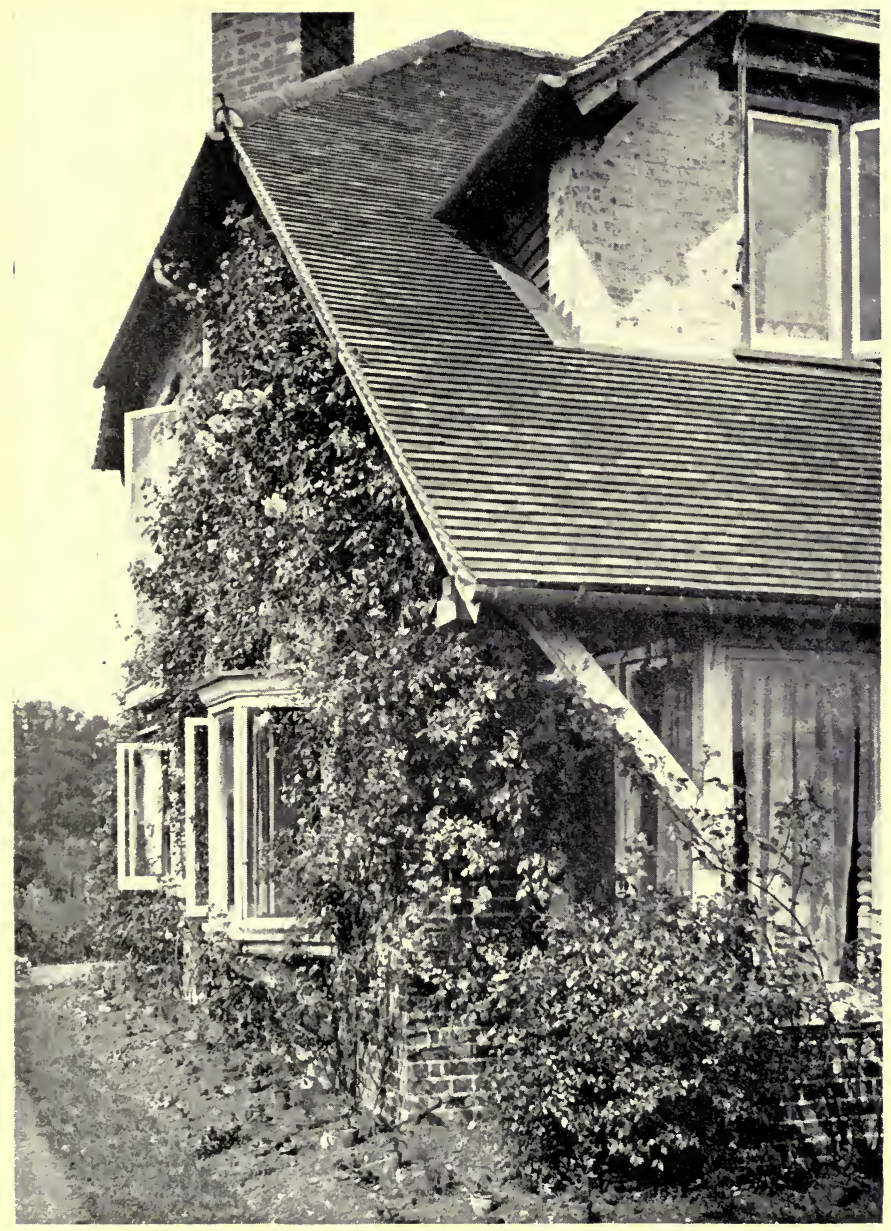

F. Mason Good, photo

Fortune's Yeliow. Keys 

an Teplitz, and above with the evergreen shoots and pale-sulphur single flowers of the Wichuraiana, Fersey Beauty, through which a vigorous Rêve d'Or has thrown long branches round the corner of the house from the north. On the other side Faune Desprez interlaces its shoots-sometimes ten or twelve feet long in a year - with the more delicate growth of Madame Alfred Carriere, whose peerless white blossoms mingle with the rich salmon and pink of Fortune's Yellow, while Ophirie at the corner below meets Climbing Captain Christy round the drawing-room windows. Fortune's Yellow is the greatest of my successes here; a source of pride and delight to its happy possessor, and of envy to the prophets of misfortune, who one and all declared I should never get it to flower. But with vivid recollections of its exquisite effect tumbling over a high grey stone wall by the dusty roadside from Genoa to Pegli, I determined to try. And each year from the ground to the roof it is showered over with scores of lovely blossoms. I cannot 


\section{EVERSLEY GARDENS}

but think that the many failures in growing this singularly charming Rose out of doors in England are due to faults of position and of pruning. It needs a position sheltered from north and east, on an extremely dry border. And any one who has attempted to prune it may be thankful to remember that it resents the knife; for it is without exception the most cruelly prickly, thorny Rose I know-every dainty twig, every shiny leaf being armed with ferocious fish-hooks. The flowers are borne singly on the well-ripened branchlets of last year's growth; so that nothing save actually dead wood should be removed; and as the Rose likes best to be left to follow its own wayward course, we must allow it, as far as is practicable, to do so, if we wish it to succeed.

Beyond Captain Christy a vigorous plant of William Allen Richardson against the porch produces about three crops of its vivid orange flowers in the year. And though it is a Rose of singularly dirty habits, attracting every vile form of blight and caterpillar, I 
overcame its uncleanly ways last year by two applications of Abol early in the season, to my great and lasting relief.

Another beautiful Climbing Rose is Belle Lyonnaise. It flourishes here on the east corner of the house, and one is always sure of some of its huge, solid blossoms till November. Though in point of perfection and size the flowers of Rêve d'Or are not to be compared with many other roses, it is to my mind one of the most delightful of all climbers; for even when out of bloom its handsome foliage and reddish shoots are highly decorative. An absurd little tin verandah outside a doll's-house cottage near by, is made glorious by four plants of Rêve d'Or and Reine Marie Henriette climbing up its little pillars and hanging a fringe of crimson and copper-yellow blossoms along its edge. When well grown, what an excellent Rose is Reine Marie Henriette. It loves a wall; but any wall, even a north one, will do, though its colour is richer and deeper on south or west. Francois Crousse, Ards 


\section{54 EVERSLEY GARDENS}

Rover, and Reine Olga de Wurtemburg are three other valuable climbers of hardy constitution: but the last is best in early Summer, only bringing a few flowers in the Autumn. Perhaps one of the most persistent of all Noisettes for pillars or arches, next to Céline Forestier, is the charming though small-flowered Alister Stella Gray. On March 30 last year I moved a plant which was being smothered in a shrubbery border, planting it against a stout eight-foot pillar; and throughout the whole Summer and Autumn it was a solid mass of blossom, every little new brown shoot from the ground upwards being tipped with flower buds.

The vitality of these Climbing Roses is a constant source of wonder to me. Sometimes, when, sick at heart, I have surveyed my ravaged garden at the end of April, it has seemed impossible that any Rose could survive the late

"Envious sneaping frost

That bites the first-born infants of the Spring."

And as I look out of my study window in the beginning of July, it is as difficult to 


\section{THE ROSE GARDEN}

believe that the garden has ever been through such an ordeal.

Over the fence against the gate, Crimson Rambler makes a brilliant background to the brown shoots and fawn-coloured flowers of a huge mass of Rêve d'Or. Beyond them the crimson Longworth Rambler, flinging itself up into a Furze bush, and orange, crimson, and shell-pink standards of William Allen Richardson, Duke of Edinburgh, and Caroline Testout, show well against a bush of Syringa backed by Furze and Broom and covered with white flowers as sweet and lovely as the orange blossom it mocks; while the border below is bright with Tea Roses just coming into bloom and an edging of mauve Viola. Further down the long border, the Penzance Sweet-briars are in glorious bloom above a fringe of white Pinks. One bush of Anne of Geierstein is a picture-a solid mass of green nine feet high and five feet through, covered with hundreds of brilliant crimson flowers with vivid golden anthers. Farther on, Flora McIvor and a huge old pink Dog Rose in the hedge have 


\section{I56 EVERSLEY GARDENS}

joined hands with a big bush of Manetti; and in the dawn, when it is too hot to sleep, the sheet of pink blossom is a refreshing sight from one's window. The Manetti was brought me from the Rectory garden by an old friend, who supposed it was one of the Roses my father had planted. And so in fact it was: but then it was only the stock upon which the more precious scion it has killed was budded. However, I am rejoiced to have it; for its charming foliage and bunches of delicate pink blossoms make it well worth growing for its own sake. Meg Merrilees and several of the pink varieties of those delightful Sweet-briars, which will always be a lasting monument to a lifetime of patient work by Lord Penzance, mingled with the dark glossy leaves of Rhododendrons and the green of Furze, Broom, and Hawthorn in the hedge, are good to behold. While the scent of a plant of Lord Penzance, the most fragrant of all the tribe, is so penetrating on damp evenings, that the village neighbours stop in the road outside to enjoy it as a pleasant change from 
the stench of the passing motor. But lovely Lady Penzance has of late been a disappointment to me. She is far more delicate than the others, partaking more of the beautiful and capricious nature of the Austrian Copper Briar than of her other hardier parent the Sweet-briar. For the first two years after planting she was a wondrous sight, a perfect fountain of flame; but she gradually dwindled away, and has ceased to exist.

Besides Sweet-briars, and the dear old Persian Yellow Briar, the border contains many bushes of that invaluable importation from the Far East, Rosa Rugosa, the Ramanas Rose of Japan. Early morning is the time to see the noble Atropurpurea in its glory; for the great single flowers which turn purplish under the sun are then deep crimson, and with their brilliant centre of golden anthers they glow like carbuncles. That touch of purple or magenta, which to my mind spoils the colour of a pink or red Rose, is the chief fault of all the coloured Rugosas. But one gladly forgives this for the sake of their handsome foliage, 


\section{58 EVERSLEY GARDENS}

and the scarlet apple-like fruits, beloved of blackbirds and thrushes, which make, the bushes so highly decorative in Autumn. To the white varieties, however, there is no drawback. The pure white, lily-like form of $R$. alba makes it a charming object in the garden. Still more perfect is the doublewhite hybrid, Mme. Georges Bruant, as exquisite as it is distinct. My first happy meeting with this bewitching lady took place in a certain garden cut out of the fir forest just below the southern façade of Wellington College, on the site of an old bog to whose depth and treachery I can bear witness; for I remember as a child getting my pony bogged up to the girths on that very spot. The charms of the Blue Hungarian Band and even of strawberries and cream on a broiling day, paled before those of a standard of Mme. Georges Bruant. It was indeed a thing of beauty; an evenly shaped head, like some huge bridal bouquet of clusters of large double-white flowers and sharply pointed buds carried on brown stems well above the soft 
Rugosa foliage. Each cluster was perfect in itself, each exactly in the right place.

Needless to say, I felt life would be a wilderness until I possessed this charming Rose. But other things had to come first; and it was only eighteen months ago that, after two years of weary waiting, I saw my opportunity. The two long Tea Rose beds, broken by an arch of Reine Marie Henriette and Queen Olga of Wurtemburg, were so scourged by the southwest wind that I had to move all their contents to more sheltered quarters. And I bethought me that in their place a hedge of double-white and pink Rugosas, with pillars of Dorothy Perkins at intervals, to break the wind from the rest of the garden, would be a rather nice idea. In the upper half, therefore, I planted Mme. Georges Bruant and the other white hybrid, Blanc Double de Coubert; in the lower half, the pink Conrad Ferdinand Meyer. They are set two feet apart, and between each three plants come the pillars of Dorothy Perkins. The latter not only flowered on every twig of the former season, but 
their shoots by last Autumn far outstripped the eight-foot posts and met along the strained wire connecting the top of each, to form this year a continuous rope of blossom some sixty feet long. The Rugosas are tied to two other wires two and four feet from the ground, and promise to make a solid hedge this season, which will be kept clipped at five feet. If Dorothy Perkins was satisfactory, the Rugosas even surpassed her. The white ones-for all this trio are perpetual-were in flower from the end of May to December. The intense drought made no perceptible difference to them-save in a touch of mildew here and there - though they were never watered. But Conrad Ferdinand Meyer, how can I sufficiently praise you? When I first saw that huge bowl of you at the Temple Show on April 30, I904, exhibited by Mr. Leopold de Rothschild, with the encouraging label "Grown out of doors without the slightest protection," I would, but for your villainous prickles, have taken you actually, as I did mentally, to my heart. 


\section{THE ROSE GARDEN}

And your great soft, pink flowers are as fragrant, with the delicious rose-sweetness of all the Roses of the poets, as they are beautiful.

As a further protection to the Tea Roses, the Hybrid Perpetuals were also moved; and their old beds, between the house and the new Tea Rose beds, planted with a dozen choice Rhododendrons shaded from deepest crimson to white, which already help to break the wind; while a row of the new China Roses, Madame Eugene Résal and Laurette Messimy, at the back, and another of the little dwarf Polyantha Roses in front, keep the borders bright when the Rhododendrons are out of bloom. It is surprising that these charming little Roses are not more generally grown as an edging to others; for they are perfectly hardy, and are covered with neat miniature flowers-white, yellow, pink, orange, and crimson-borne in corymbs at the end of every shoot, from May to November.

In the Garden of Delight, great use is made of the old-fashioned Summer Roses. In early 
July pillars of Laure Davoust - a very old hybrid of the original Rosa Multiflora brought by Thunberg from Japan in 1804 - bearing clusters of very double flowers varying from red to almost white in enormous quantities, are in full beauty. The old snow-white Madame Plantier - a Rose I delight in for its purity of tone and delicious scent-is allowed to form grow-as-you-please bushes. Another old favourite too rarely seen nowadays, the hybrid Bourbon Charles Lawson, is treated in the same way. While Rosa Simplex scrambles over a high mass of shrubs, Crimson Rambler walks up a dead tree; and The Garland, Félicité Perpétuée, Bennet's Seedling, and all the Ayrshires, trained over arches and pillars, and flinging long wreaths of blossom up trees and over shrubs and walls, make an exquisite and bewildering background to the more modern Hybrid Perpetuals, Teas, and Polyanthas.

The old Rose Bennet's Seedling or Thoresbyana, found among some Briars by Lord Manvers' gardener at Thoresby about 1840 , is not as 


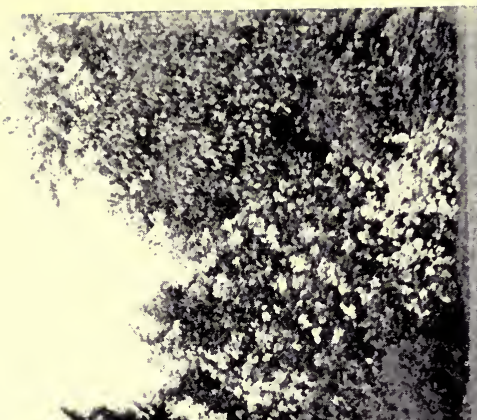

$\ddot{0}$

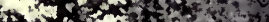

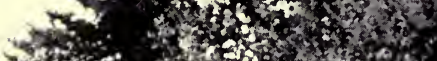

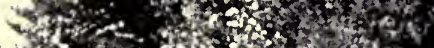

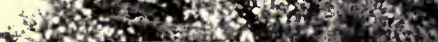

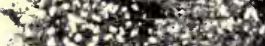

$-6023602025$

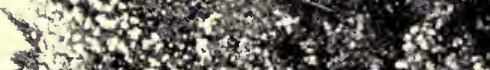

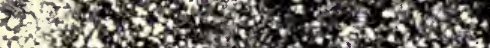

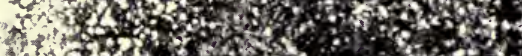

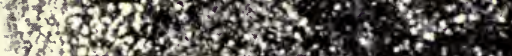

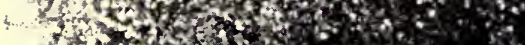

s.t.t.

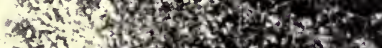

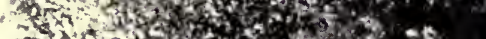

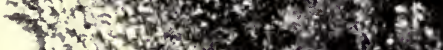

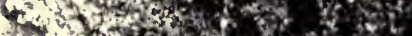

- nit.

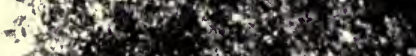

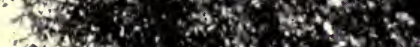

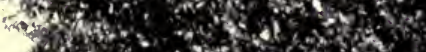

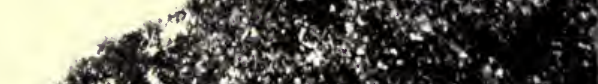

thos 0 .

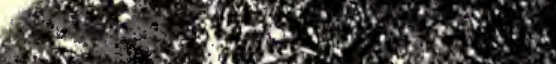

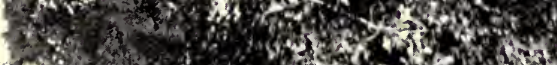

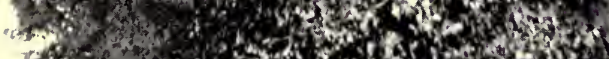

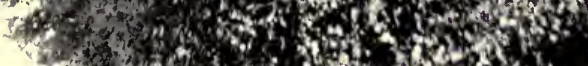

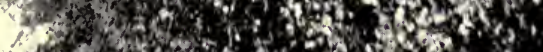

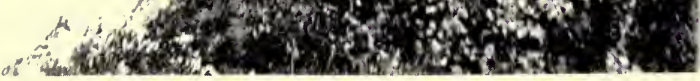

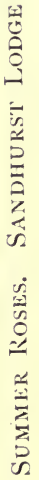

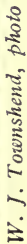





\section{THE ROSE GARDEN}

much grown as it might be. It is deliciously fragrant, and its neat clusters of small fairly double white flowers are borne in amazing abundance. I have seen various recommendations of late to plant it with Crimson Rambler, "as they flower simultaneously." But this is not my experience; as 'Bennet's Seedling is over here before Crimson Rambler is out. I have, however, planted it with Rubin-a most excellent Rose, by the way; and the effect of the dark foliage, red shoots, and crimson flowers of the one, mingling with the snowwhite clusters of the other on a large arch, is one of the prettiest things in the garden.

Of the newer Rambler Roses, Leuchstern, Euphrosyne, Queen Alexandra, Psyche, Tea Rambler, Mrs. F. W. Flight, the beautiful Blush Rambler, and Waltham Rambler-looking at first sight like some single pink hedge Rose worthy to grow on Olympus, but flowering in great panicles-are all valuable among the pink shades. And Aglaia, Claire Facquier, Waltham Bride, Perle des Neiges, Thalia, Polyantha grandiflora and $P$. Simplex, represent yellow and white 


\section{I64 EVERSLEY GARDENS}

in this charming group. But the Wichuraianas are even richer in delicate tones of white and yellow. The whole Wichuraiana family are among the most precious of recent introductions; and the way they have raced into European fame and favour testifies to their worth. From the tiny single white flowers and close set evergreen leaves of the original type Wichuraiana, to the fine double creamy flowers of Gardenia and other hybrids, all are delightful. The charming Dorothy Perkins needs no praise of mine, for never was there a more captivating inhabitant of the garden with her pure pink blossoms at the end of every twig on last year's shoots. On pillars, arches and screens there is not a more attractive Rose; though Lady Gay is by some considered even more beautiful; and, like all Wichuraianas, the glossy foliage is practically evergreen, while the flowers last on through early Autumn. Another hybrid, W. Rubra, bearing small single crimson and orange flowers, makes an attractive weeping standard, as its growth is not quite as overwhelming in 


\section{THE ROSE GARDEN $\quad 165$}

vigour as the others. That these charming Roses will grow up a wall, I have proved by my fine plant of Fersey Beauty. And on a high fence beside my study window Evergreen Gem has formed a thick screen from the east, green all the Winter, and a sheet of sulphur-white blossom in Summer, a vigorous white Everlasting Pea being the only thing that manages to hold its own among the strong shoots. But most of them are undoubtedly happier if allowed to scramble as they please. A neighbour who has used them as they should be used-namely, as trailing Roses to cover large spaces on banks-has a wonderful show in July. The steep banks on a terraced, sandy slope above her Rose garden, are planted with Evergreen Gem, Gardenia, Fersey Beauty, Alberic Barbier, \&c., whose rampant shoots have spread in thick shining masses of glossy foliage, and white, cream, and yellow flowers over the whole slope.

It is always interesting to note that whatever may be the vagaries of Teas, Hybrid Teas, and Noisettes-flowering some years early, some 


\section{I66 EVERSLEY GARDENS}

years late-the Hybrid Perpetuals keep the even tenour of their way, varying but a very few days in the matter of blooming. "The Expert" (in Roses and much else) was pointing this fact out to me one early Summer day; and I was forced to admit that his remarks were, as usual, correct and scientific. But I was annoyed with The Expert; as he had taken occasion to tell me that the day before he had cut dozens of splendid flowers from the bed of Papa Gontier, in his Thames Valley garden. It is not kind to come down from London on purpose to see Fortune's Yellow, and then say such disagreeable things. But I thought it was probably jealousy, as he has not got Fortune's Yellow.

A fortnight later I was humbled to the dust; and I felt the deepest sympathy with the Queen of Sheba's feelings on her visit to King Solomon. I spent an afternoon with The Expert in that tiny garden. I knew, from what others had told me, that it might be a trial to my friendship; but the half had not been told me. And in my ignorance and 
conceit 1 had called The Expert proud. My only wonder is that he has ever condescended to look at my poor possessions.

Never outside a show have I seen such Roses; and Roses are not all in that little garden. Yet it is ibarely half an acre; and when he took possession in November 1902, it was a mere dumping-ground for the rubbish of the large house over the wall; while the little pond to which the Kingfisher comes to feast on gold-fish was half full of old pots and pans.

That pond is a treasure. The tons of mud which were taken out before tall bulrushes and fine water plants were planted round its edge, have gone to enrich the marvellous Rose beds and the rockery - though, in sooth, the natural soil of the garden, a rich clayey loam, needs but little help. Its sloping banks on two sides have been cut straight down, and by means of strong posts and wattles made into a solid wall, with a narrow grass path on the top; while the earth has been heaped up above into an enchanting ridge, partly rockery, but mostly everything-for it is impossible to enumerate 
the masses of flowers that cover it. Here, on a small dead willow, a Wistaria is fighting with a vigorous Ards Rover for possession. A stump close by is covered with the huge stars of that loveliest Clematis, Nellie Moser, and a plantation of the noble Incarvillea Delavayi crowns the rockery beside it. The rich brown leaves of Lobelia Cardinalis give promise of a wondrous show in September, with Hydrangeas and Lilies; and a dull flame-coloured Ixia seems to have naturalised itself against the little steps that lead up the ridge to the path above, for it had to be greatly pushed aside before we could go up or down. From a comfortable seat in a shady corner under the ridge, the grassy slope across the little pond made a charming picture, with various Wichuraiana, Penzance and other Roses growing as they pleased in the turf-delightful objects, which confirmed my belief that we do not use Roses nearly enough in this way. As in this instance, they should be planted sufficiently far apart to allow the mowing-machine and their admirers to move freely among 
them; and that done they should grow according to their own sweet wills. A Dorothy Perkins at the farther end of the ridge, its main stem supported by a strong stake, was flinging its long shoots about in the most fantastic fashion.

But now for the Roses. Coming in from the gate in the dusty high-road, an 8-foot screen of wooden trellis is planted with alternate plants of Crimson Rambler and Reine Olga de Wurtemburg; and a wonderful mixture they made, their colours blending as harmoniously as did their clean vigorous shoots; while at the end close to the entrance to the garden, a fine specimen of Leuchstern was so covered with bunches of flowers that the leaves could hardly be seen.

But when, between thick borderings of Mrs. Sinkins pink, I reached the garden proper, I fairly held my breath. I repeat that never, save at a show, have I seen such Roses. One could hardly distinguish some, so enormous and perfect were they, from the Pœonies of my good friend Dessert, of Chenonceaux. 
The Roses are mostly grown in numbers of small beds. One set filled with dwarf Roses, contain some eighteen to twenty-four plants in each. Here are a few of the most striking: Bed I. Twelve plants of Liberty, with Mrs. $W$. 7. Grant in the centre. 2. Killarney and Caroline Testout, a singularly beautiful combination. 3. Here Mme. Abel Chatenay reigns alone. 4. Mme. Pernet Ducher and Papa Gontier-a rare pair, rivalled in 5 by Caroline Testout and Gustave Régis. 6, 7, and 8 are devoted to the newer kinds of China Roses, the last being filled.with Mme. Eugene Résal and Laurette Messimy.

In a long border under the north hedge, planted at each end with perennials, Lilies, standard Lilacs and so forth, the centre is devoted to a grand group of dwarf Hybrid Perpetual Roses. It is a singularly effective arrangement in colour. In the midst are six superb plants of Frau Karl Druschki, then in glorious bloom, two in the back and four in the front row. On each side are two pink Roses, so planted that one comes behind each 


\section{THE ROSE GARDEN}

of the outer Frau Karls in the front row, and the other beside it. These are followed right and left by twelve brilliant red Roses, also planted in a double row. On the left as we look at the group the two pink Roses are Mrs. Fohn Laing. Then come two each of Gen. Facqueminot, Prince Camille de Rohan, Duke of Edinburgh, Dr. Andry, Victor Hugo, Duke of Teck. On the right-pink, Mrs. Sharman Crawford; red, François Michelon, Baron de Bonstetten-a bad Rose, not worthy of such company-Fisher Holmes, Duke of Wellington, Captain Hayward, Horace Vernet.

In a cross bed Susanne Marie Rodocanachi (one of my greatest favourites), Roslyn, Coralina, Prince Arthur, Marquise Litta, and Caroline Testout made a charming mixture; some other fine dwarfs being the brilliant yellow Georges Schwartz, Gladys Harkness, Empress of Russia, Maman Cochet, and Souvenir du Président Carnot.

A number of half-standards filled other beds. Among these the fine scarlet-crimson Captain Hayward-an admirable Rose in all 


\section{I72 EVERSLEY GARDENS}

ways and very sweetly scented-was most striking. Others of great beauty among the half-standards were Duke of Teck, Victor Verdier, Mrs. Sharman Crawford, Horace Vernet, Louis wan Houtte, l'Idéal, Xavier Olibo, Viscountess Folkestone. But it is impossible to pick out more than a tithe among the wealth of colour, form, and fragrance of these wondrous Roses. And I was so absorbed in looking at the marvels growing at my feet, that I had spent a full hour in the garden before I happened to lift my eyes to a blaze of Ards Rover on the trellis fence inside the eastern hedge along the road. When lo! over the vivid crimson of the flowers, rose the glorious mass of the Round Tower and Windsor Castle a mile away, bathed in brilliant sunshine against the blue sky. And even Roses were forgotten in the proud memories that stirred one's heart. 



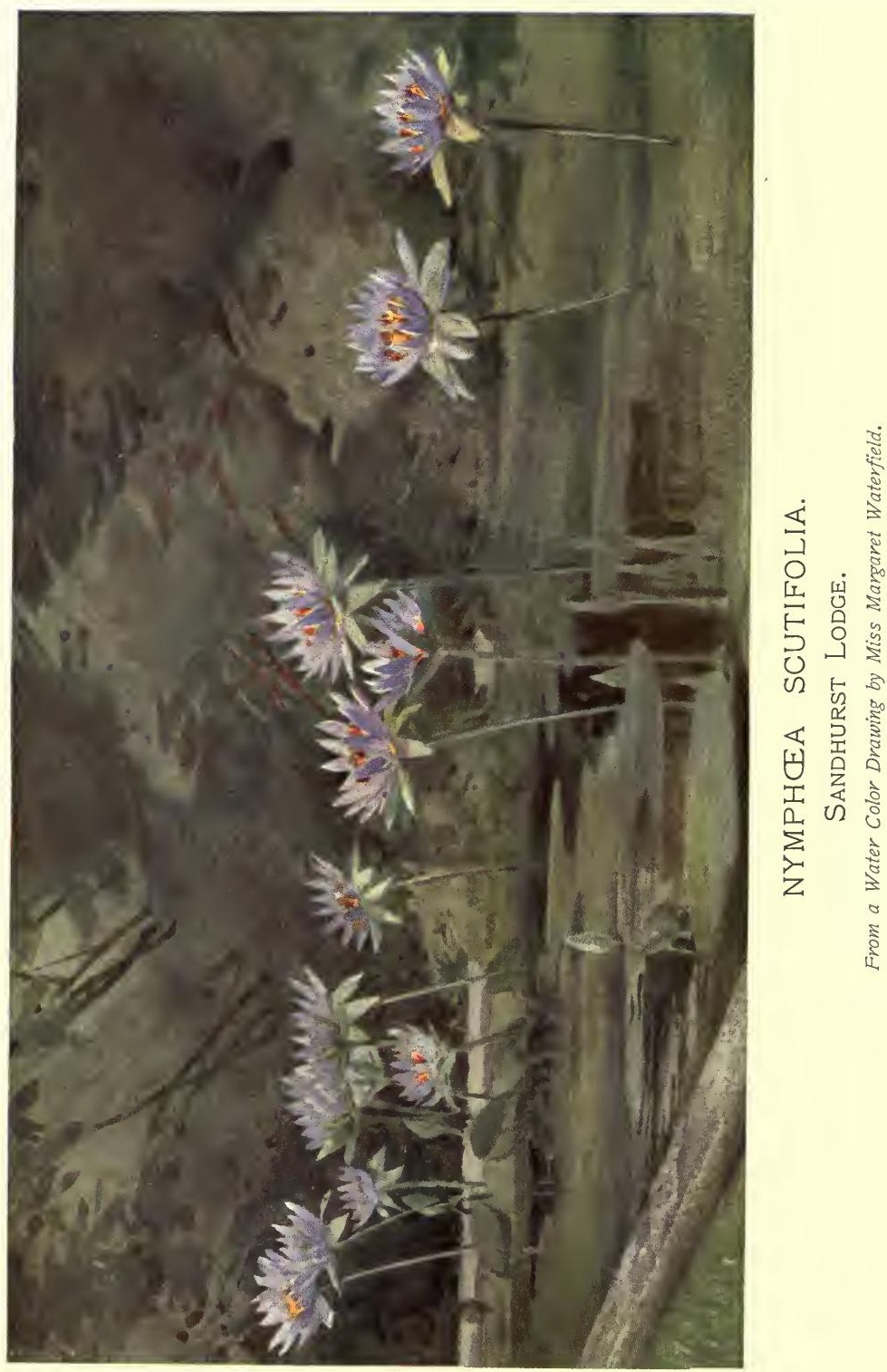




\section{CHAPTER IX}

\section{A GARDEN OF DELIGHT}

I HAVE scant sympathy with a certain clerical groom-gardener of our acquaintance, who, when asked with profuse apologies to leave his digging at a psychologic moment and drive to a village flower show, replied with alacrity, "I always loves to go around and see how bad they does." Though his wife was a member of the Salvation Army, yet, as a west-countryman and a strong supporter of the Establishment, he might have exercised the third Theologic Virtue with greater fervour. My point of view, however, is that there is nothing so stimulating to the gardener's mind as the sight of a great garden, where perfect taste and profound knowledge go hand in hand with wealth, and this is a far rarer sight than might be imagined. 
I74 EVERSLEY GARDENS

It is always, therefore, in an eager and delightfully expectant condition of mind that I drive over from time to time to a celebrated garden that lies three miles away, where Hants, Berks, and Surrey join hands, and my happy expectations are never disappointed. For, unlike other works of art, there is no finality in such a garden. The picture once painted, the statue once sculptured, it is finished. But the garden goes on growing as long as time and love of it shall last; each succeeding year adding some fresh touch to the beautiful conception. And this Garden of Delight never fails in fresh surprises. So that no matter at what time of year one sets foot in it, one's eye and imagination are alike satisfied, one's ambition stimulated, and one's mind filled with lovely pictures, which come back as light in a dark place during long wakeful nights or gloomy Winter days. On one visit at Whitsuntide it was in all the glory of Rhododendrons, great bushes, nay, almost trees, of purest white, pink, and crimson, against the dark firs and sprouting heather. Three 


\section{A GARDEN OF DELIGHT I75}

months later, in full Summer-tide, the beds on the great flat space of close-cut lawn before the southern face of the house, were radiant with tall Fuchsias, and Geraniums of many sorts as tall, purple standard Heliotrope, pink Verbena, with Cannas and madder-brown Ricinus, strange sub-tropical plants and Begonias of gorgeous hues. No formal ribbon borders are here; but exquisite combinations of all sorts and kinds of flowers, common as well as rare. And looking beyond this last word of gardening art across the deep dip of the lawns, rose the most subtle touch of all, a knoll, a quarter of a mile away, of native Heather in full bloom, crowned with the blueblack of our wild Scotch-firs, and backed by the noble view over the vale of the Blackwater to Hartford-bridge Flats, and the faroff Beacon Hill and Cæsar's Camp frowning down on the modern Aldershot.

But flower beds, and even such a view, are not our goal in this dear Garden of Delight. And all steps turn sooner or later to the long steep slopes of the lawn-a veritable hillside 


\section{I76 EVERSLEY GARDENS}

of close-shaven greensward, set in one spot with tall, old-fashioned Geraniums, Fuchsias, Plumbago, and what not, sunk in the turf in their pots, with space enough left between to walk among them. Flights of steps in the centre of a high brick wall supporting a terrace walk below the lawn, the old fig trees along it half-smothered in a tangle of climbing Roses, Honeysuckles, and every sort of creeper, lead down to the velvet croquet and tennis grounds. And crossing them, we come to a broad walk between borders filled in wellordered but not formal array with bedding plants-Verbena, Viola, Celosia, Pentstemon, and a dozen others, the long lines at the back broken at intervals with standards of Hydrangea paniculata rising out of a cloud of Nicotiana Sandere; and so, past the iron gates of the great walled kitchen garden, to the Wild and Water gardens at the bottom of the little valley.

This is the very heart of the Garden of Delight-a triumph of knowledge, taste, and the finest art. On the right of the wide straight 


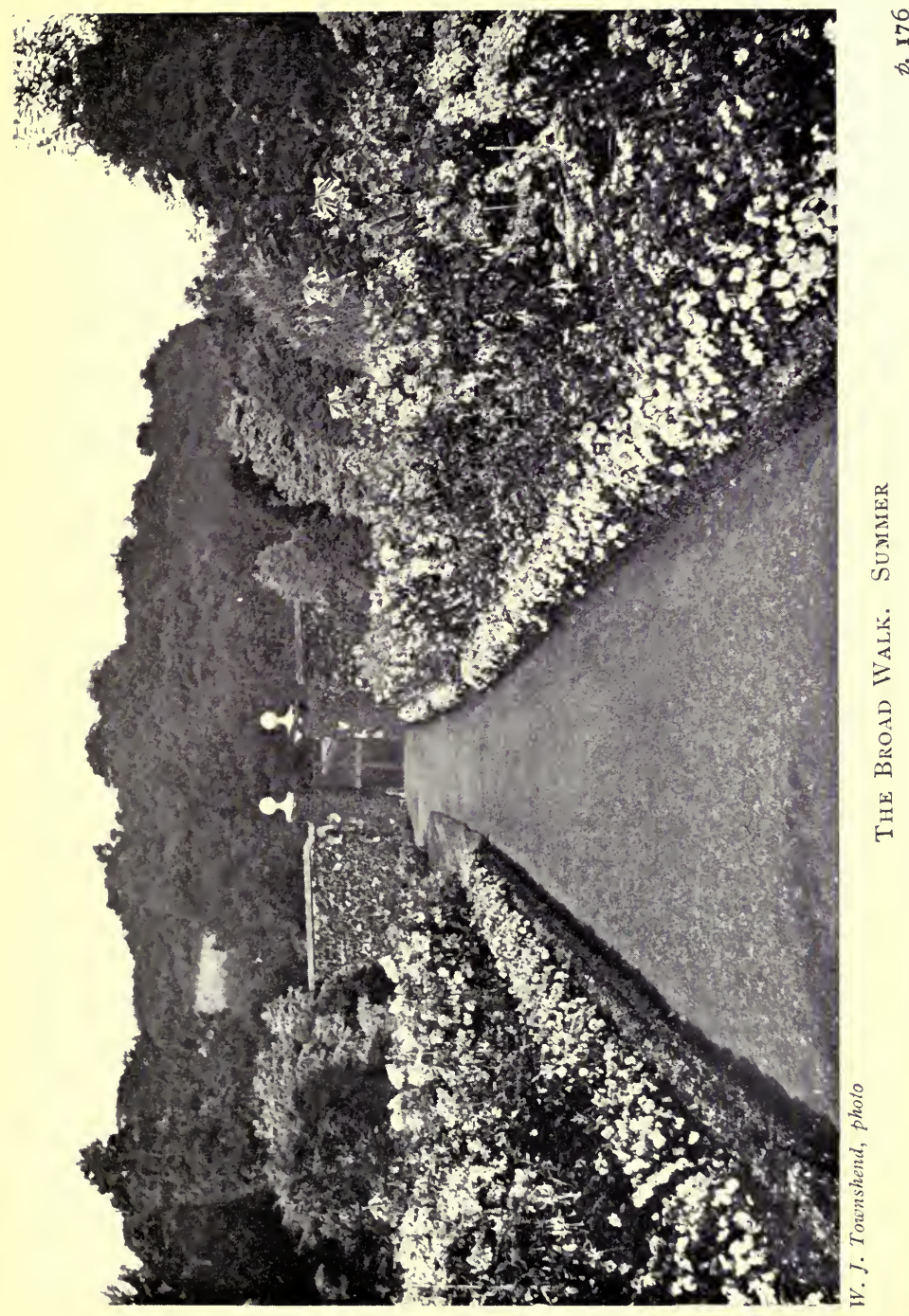





\section{A GARDEN OF DELIGHT}

walk below the high southern wall of the kitchen garden, runs a space of fruit trees, with a delightful broad mixed border melting into it in front. Here are great Rose bushes of all sorts and kinds, the old pink China attaining an immense size; plantations-I can use no other term-of Hollyhocks, the fig-leaved single kind growing with fine effect, here a mass of sulphur, there of darkest maroon; and other herbaceous and annual flowers of every imaginable variety. On the left, sunk in the softest green turf, a line of five or six small round ponds, through which a clear little stream of our soft, brown bog water flows gently. And in each pond Water Lilies! Water Lilies from every quarter of the globe. Water Lilies of every shade, beginning with purest white of our English Nymphaea alba in the big pond at the head; and running through lemon, yellow, and pink to crimson. Even the rare blue Lily $N$. scutifolia, from the Soudan, grows here in the open air; but it is obliged to have its own tanks under the terrace wall, with hot-water pipes running 
through them to keep up the temperature of the water. It thrives so greatly, however, that the young surplus plants are planted in the Lily ponds during the summer; and the effect of their blue star-like flowers carried high above the water on upright stems, among the pale sulphur and rose-pink of the other Lilies, is a joy to behold. To see the Lilies in perfection they should be visited in the morning. But on this special afternoon the skies were grey, and the flowers, which generally close soon after midday, had opened later than usual and were in perfect form, a dream of delight.

Along the sloping green turf between the walk and the ponds, standard Fuchsias, tall plants of Heliotrope, Plumbago, and Sweetleaved Geraniums of many sorts, were sunk in pots; while among them, long shoots covered with the scarlet lobster-claw flowers of my dear old West-Indian friend Erythrina Christagalli, whose seeds are the scarlet and black " jumby beads" of our childhood, made a brave show. It does one good to see an old 


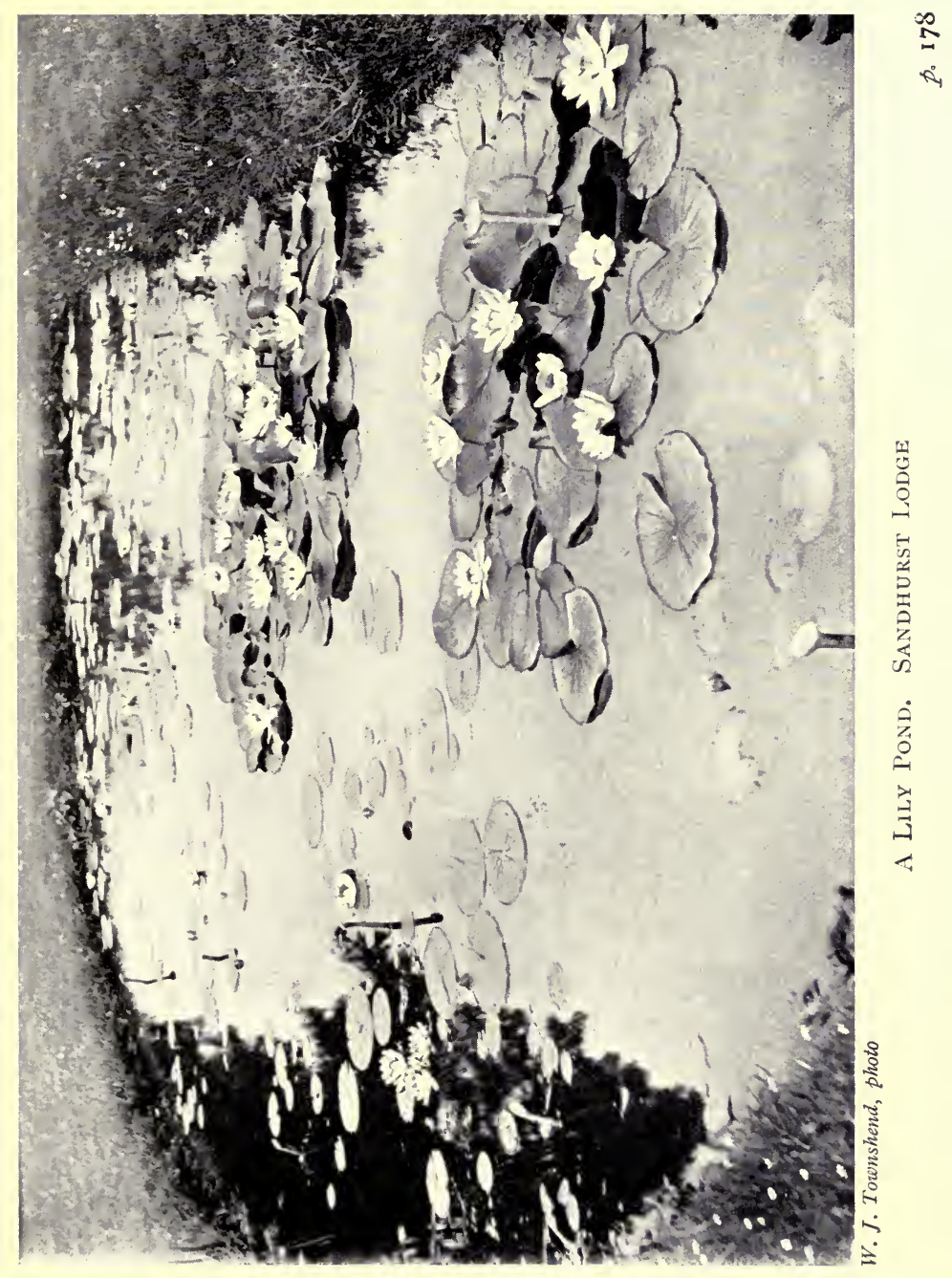





\section{A GARDEN OF DELIGHT 179}

friend, even in a pot. Yet brave as the scarlet lobster-claws looked, my heart flew back with a sudden pang of longing to a hedge of Erythrina we came upon in an early ride up from the Laventille circular, towering above the path, beside which a huge negro was clearing away the sulphur Thunbergia alata with a sickle, as we should clear goose-grass from our hedges. But return, my heart, from Trinidad to this Berkshire garden-not such a poor place after all, even though it is not in the tropics. Your travelling days are over, therefore be content with nature and art near at hand, and you will find rest and peace.

On the farther side of the ponds, in subtle contrast to this extreme of civilisation, all kinds of wild and water-loving plants, yellow Iris from the Blackwater meadows, purple Loosestrife, blue Geranium from the Thames, and so forth, are allowed to grow at their own sweet wills in an admired tangle, with reeds of many kinds, and here a blue Eryngium, there the great white heads of Hydrangea paniculata, till the eye is carried far back over the winding 
ways and masses of the Wild garden and all its treasures into the leafy heart of the untouched oak wood. But one fairy spot remains at the western end of the valley beyond the ponds. Approached through a grove of standard Fuchsias, a grassy floor under lofty trees is thick set with a mass of pink Hydrangeas against the dense copse and wood that slopes up to Finchampstead Ridges and its heatherthe lovely ending of our lovely pilgrimage.

Many and exquisite are the phases of this Garden of Delight. Yet perhaps it is never more enchanting than in bulb time. And what may be done with an unlimited quantity of Daffodils of all sorts and kind, was revealed to me one Spring day some three years ago. Its gifted creator, whom I am so proud to call my friend, had said, "Come and see my Polyanthus and Daffodils;" and naturally I hastened to respond to such an invitation. At each turn it seemed as if the actual limit of beauty must have been reached, as we journeyed leisurely from the beds of Polyanthus in front of the house, and Magnolia stellata in a sheltered 

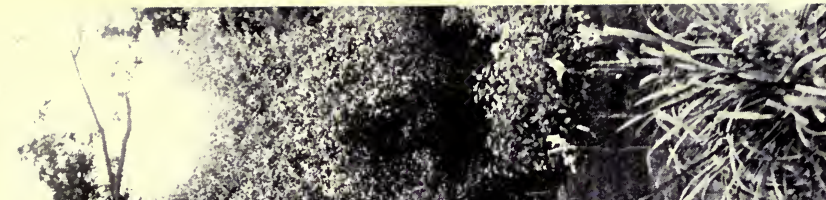

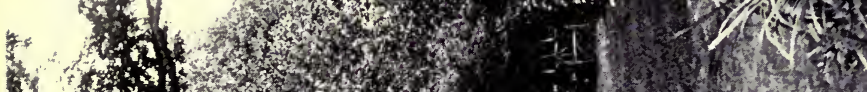

(1)

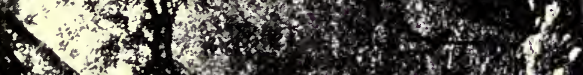

r.

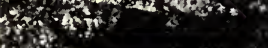

itis:

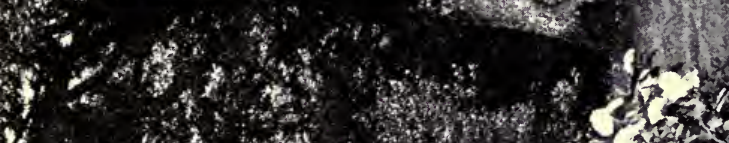

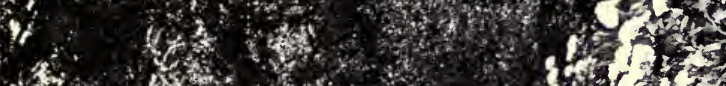

$4=5$
$a^{\prime}$

$\infty_{\substack{0 \\ \infty}}^{\infty}$

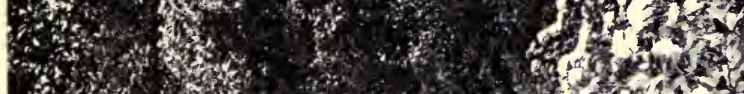
tes

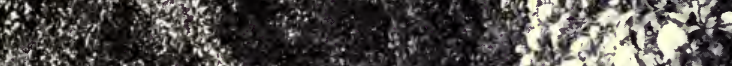

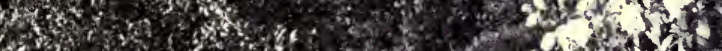

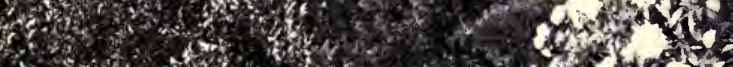

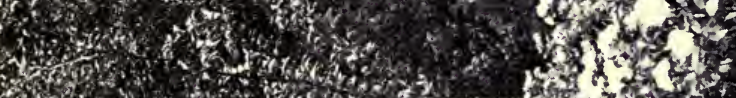

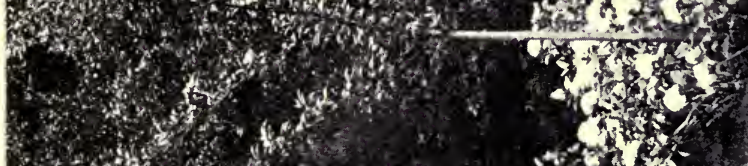

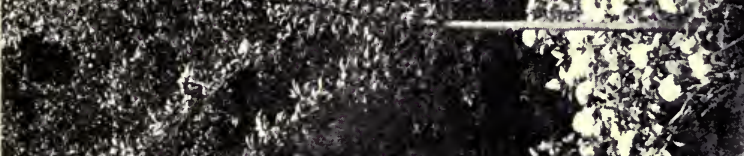

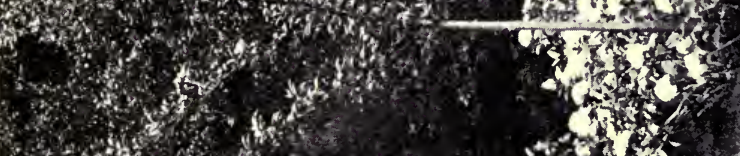

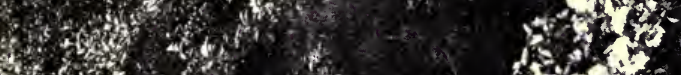

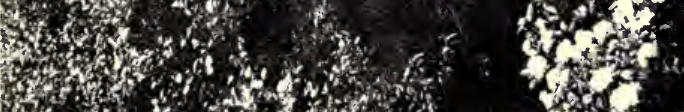

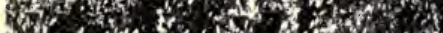

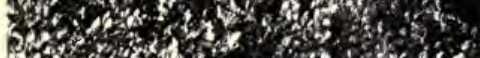

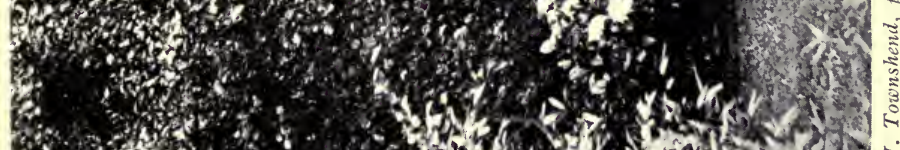

if

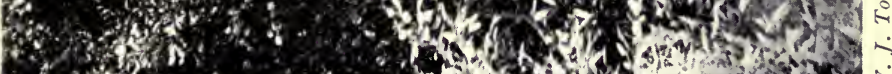





\section{A GARDEN OF DELIGHT I8I}

corner, across the lawns and the steep Rock garden on the slope. Then on by pathways arched over with trained Pears in full blossom springing from narrow borders crammed with brilliant Spring flowers, where white Narcissi and Ornithogalum (to be succeeded by Tulips of all colours) rise from the grass among pyramid Plums and Apples. But all this was as nothing to what was to follow.

On each side of the straight path towards the Water Garden, the broad borders, filled eight months before with a glory of Summer flowers, were now a mass of nothing but seedling Polyanthus, so thickly planted as to hide the earth, backed by Wallflowers and the pointed buds of Golden Crown Tulips to come, among which the standards of Hydrangea stood, now bare and closely pruned, to delight us in Summer with their great heads of white. But when we turned past the kitchen garden and reached the line of Lily ponds of the valley, I confess my breath came short. It was indeed a living poem written in flowers that lay before me. A tracery of white pear blossom ran over the 


\section{I82 EVERSLEY GARDENS}

red of the high kitchen garden wall on the right; and for some two hundred yards along the straight edge of the wide herbaceous space beneath it, where fruit trees were coming into flower, lay a band two feet wide of solid colour -a thick close mass of two-year-old Polyanthus of every shade; while here and there a double pink Plum, or brilliant flowering Peach was set off by the tender brown of large standards of Prunus Pissardii just coming into leaf, or the pure white of a Cherry. On the left of the long walk, and lovelier still, lay the Lily ponds and the Wild garden beyond them. In the sloping turf between the walk and the ponds, the place of last Summer's tall Fuchsias, Plumbagos and Erythrinas was now taken by sunk pots of equally charming, if less vivid, flowering Plums and Peaches and Cherries, with the delicate white sprays of Spiraa Thunbergii and S. prunifolia, \&c. The little island on the large pond was crowned above the green of budding shrubs with a pink Cherry in full bloom against a tall white Plum. And on the edge of some of the Lily ponds-subtle touch 


\section{A GARDEN OF DELIGHT I 83}

of the true artist and lover of nature, to whom all beautiful things, whether found in the nearest meadow or brought at much cost from the ends of the earth, are alike precious and worthy of reverence-great plants of the common Kingcup shone like masses of pure gold beside the young pads of Lilies from Asia and the New World.

But beyond the ponds, under the forest oaks that are left standing to give enough and not too dense a shade, the Wild garden called us; and with Herrick rather than with Wordsworth we murmured-

$$
\begin{aligned}
& \text { "Stay, stay, } \\
& \text { Until the hasting day } \\
& \text { Hath run but to the evensong, } \\
& \text { And having prayed together, } \\
& \text { We will go with you along." }
\end{aligned}
$$

For in the cunningly devised promontories and islands of grass and plants left among the spaces of close-shaven turf, Daffodils of every sort and every shade grew in thousands upon thousands, with here a glint of crimson or purple from Polyanthus, there the deep 


\section{84 EVERSLEY GARDENS}

brilliant blue of Grape Hyacinth; while Forget-me-not and white Anemone, and even the common white and pink-tipped Daisy, sprang beneath them in the grass. The wild Lent Lilies were over, and many of the Trumpet Daffodils were nearly past, though there were some splendid Emperors in a shady place. But all the short-cupped, Star varieties were in fullest glory, planted in fairy groves each kind by itself. And they carried the bewildered and enchanted eye away and away to the dusky recesses of the wood, and the Spring greens and browns of the sharp slopes of the copse, against which a tall pink-flowered Cherry stood, a proud and graceful sentinel. These lovely bulbs are left to grow at will in the garden, where, as they die down, their place is taken by a succession of other flowers. Many were rare, such as the delicately yellow Queen of Spain, the white Cerneus, the quaint lemon Cyclamineus. But wondrous fair as each kind appeared, the effect as a whole was so absorbing, that one could not stay to be botanical or horticultural; one merely drank in the beauty, 


\section{A GARDEN OF DELIGHT 185}

and marvelled at the skill that had produced so perfect and restful a harmony.

Even yesterday a totally new phase of this dear garden was revealed to me; for the wild Lent Lilies were in full flower. Sheets of pale gold spread under the great leafless Oak trees in the Wild garden, and up the steep slopes of the copse. And outside the confines of the garden, in the farther wood where the undergrowth has been cut this winter, the delicate flowers rose in millions-a never-to-be-forgotten vision of beauty-in the hot April sun; while among them white Wood-anemones lay in snowdrifts, and the glossy leaves of Bluebells that will soon take their place were already pushing up through the soil. But tame as well as wild delights were there. For passing the mats of double white Arabis pierced with intense blue of Scilla Sibirica beneath the Pear arcade, we came in the Wild garden upon a plantation of magnificent white Hyacinths set off by the red shoots of Tree Pœonies among them; and just beyond, scores of the exquisite little Primula rosea in full bloom were revelling 


\section{I86 EVERSLEY GARDENS}

in a damp spot under the trees, and a still larger group of $P$. Faponica gave promise of grand effect later on. The grass walks were outlined by hundreds of blue Grape-hyacinths growing among the Daffodils along the edges, or farther on by Scilla Sibirica. And thousands of choice Daffodils were coming into flower in every direction, blending exquisitely with their wild brethren. A new bit of the sloping copse has been taken into the Wild garden this winter. And with such a ready-made foundation as indigenous Daffodils, Anemones, and Bluebells to start with, big plantations of Iris Kempferi and I. Germanica, choice Clematises on a rootery, and sturdy Dielytras just coming into bloom along the edge of a grass walk, looked as if they had been growing there for years instead of months.

But returning to the well-known older portions of the garden, even the wild Daffodils were eclipsed by the earliest of the flowering trees. Here a Forsythia rose golden out of a golden mass of Emperor Daffodils. A sudden turn showed an old white Plum tree against the 


\section{A GARDEN OF DELIGHT I 87}

intense rose of a double Peach. And as climax, the great trees of Prunus Pissardii were huge spheres of delicate pink blossom, their falling petals powdering the straight walk by the Lily ponds with drifts of faintly blush snow.

The whole of this garden is the most perfect artistic blending of wild and tame I have ever found. It demonstrates what may be accomplished by faultless taste, great knowledge, and, above all, a real and deep love of beauty. Of course, one knows that such triumphs are not within the means of ninety-nine in a hundred. But all sense of the great cost, which is often far too painfully and obtrusively present in big gardens, vanishes before the artistic apprehension of the fitness of things, the beautiful sense of nature, which reign in this entrancing spot. And at every turn one becomes aware that its gifted owner and his accomplished head-gardener regard each flower, each plant, with as reverent an affection, as deep an interest, as that which the poorest cottager bestows on his one Geranium. 


\section{CHAPTER $\mathrm{X}$}

CUT FLOWERS, AND A FEW HINTS ON THEIR ARRANGEMENT

OF all the tests of friendship none, I think, is greater than to permit our friends to arrange flowers in one's own house, or to be permitted by them to arrange flowers in theirs. I only know three people among the whole of my relations, friends, or acquaintance, to whom I can entrust the gathering and arranging of my flowers with perfect confidence. And as for risking precious friendships by daring to offer help in "doing the flowers" for any one else, I am much too old and wary to dream of such folly, even though my fingers may ache to improve on what seems to me a deplorable arrangement. For every one has their own very definite views on this matter. And to see those views disregarded or badly 
carried out, is a more fruitful source of intense nervous irritation than even a visitor's dirty hobnailed boots on a parquet floor, or coals dropped by an officious hand on one's best new carpet.

Almost as much of the decorative value of cut flowers depends on what we put them in, as on how they are arranged. Visions arise of variety-show posies in glass vases of evil, crinkled shapes and yet more evil colours -crude blues, greens, yellows, and pinks, "ornamented" (save the mark!) by lumps in contrasting tints applied to the surface, like half-melted poisonous lollipops. They swore badly with the many-coloured flowers that were thrust into them to perish for want of sufficient water-space. Indeed their only merit was that they blew over with the first draught, and, let us hope, were broken. Flowers and their receptacle should always form a harmonious whole; and the vase should never distract the eye from the blossoms it holds. Beautiful glass is now so cheap that it is within the reach of every one. Take, for 
instance, Mr. Powell's glass from the Whitefriars' Works. How perfect it is for our purpose; clear white, opal, straw-opal, and bottle-green. The soft tints-straw-opal and bottle-green for choice-harmonise delightfully with any flowers; while, as graceful and practical in form as in tint and texture, the vases give room for a plentiful supply of water for the stalks.

We have learnt much and have yet more to learn from the Japanese, with regard to cut flowers. A single stalk of white Lilies in a precious pottery vase of dull blue or peach-blow; a branch of flowering Cherry, Plum, or Apple set in the stern and noble lines of a bronze jar -what a perfect picture they make. And how the sunny, wainscoted sitting-rooms of ancient English manor-houses come back to us, as we fill an old blue Nankin bowl with heaped up, freshly-gathered Roses. One of the most perfect bits of decoration in a small way that I have seen of late, was one of those solid, pure crystal jars, set on a foot of gilt bronze, that are only to be found at M. Enot's in 
the Rue des Pyramides, so like real rock crystal that you wonder whether that skilful artist has not been rifling the royal treasure of the Louvre hard by. One day it was filled with six or eight pink and white single Tulips with their leaves, rather sparsely arranged; another week with Empress Daffodils; yet another with a few Roman Hyacinths and blood-red Tulips. And if the rest of the charming room had been as bare as a barn, this one vase would have stamped its owner as the true artist she is.

In Daffodil time what a delight it is to deck the house with them. A handful of Emperor, Empress, and Princeps, in a blue Delft jar on the mantelpiece opposite my table, is enough to distract me from work on an April morning. One misses so much of the beauty of these great Trumpet Daffodils if they are below the level of the eye; and only as we gaze up into the very heart of each flower do we know its true value. The Medium Crown or Star Daffodils we can place anywhere; for their sweet faces look right up 
at us in kindly greeting. Not to mention the great Sir Watkin, Barrii Conspicuus is one of the very best as a decorative variety of the class, with its broad soft yellow perianth, its crown tipped with scarlet-orange, its fragrant scent, and strong growth. It forms a fine contrast to the white perianth and lemon cup of the smaller Duchess of Brabant, which is invaluable for cutting. One of Enot's fanshaped crystal vases filled with a little forest of these sweet and graceful flowers, against a wonderful handmade paper of strange colours in a tiny sitting-room, made a charming picture last Spring.

One exception, and one only, which I make to my dislike of coloured glass for flowers, was a gift to me for my dinner-table when I "hung the crane" in my present home. The set of sturdy little Corinthian glass jars, of strange iridescent green, made in imitation of the long-buried glass of the ancients which modern excavations have brought to light in Greece and Egypt, are, I confess, a constant pleasure to me. All the Summer through they 
are filled in succession with Roses, Carnations, and Sweet Peas, each with their own foliage. First there are the great pink blossoms of Magna Charta, three in each jar, and well furnished with their rich handsome leaves; or the crimson clusters of $R u b$ in relieved with some of its small green and red shoots; or the buff-yellow of the Rêve d'Or, that smothers the outer wall of the dining-room, and makes so fine a nesting-place for thrushes and chaffinches. Then comes the turn of Carnations-one week the salmonpink, another the deep crimson clove, another, for a change, Marguerite Carnations of all colours mixed up together-their grass coming in usefully to mix with the more precious true Carnations, whose every shoot is wanted for layers or cuttings.

And the Sweet Peas-how easy they are to arrange-how delightfully decorative are they in one or, at most, two colours at a timethe whole table dressed with the crimson of King Edward VII., the delicate pink of Gladys Unwin, or the flame-salmon of Miss Willmott. If the day is very scorching one may take a 
194 EVERSLEY GARDENS

cooler scheme of colour, and mix the pale lavender of Celestial or Lady Grisel Hamilton with the soft warm pink of Oriental; or, cooler still, the white of Dorothy Eckford and pale primrose of Mrs. Kenyon; or again keep exclusively to the delicate beauty of Dainty. But of all Sweet Peas for the table, the pure cerise of Coccinea is far the most effective by candle or lamplight. With all these delights I use their own foliage freely; the grass of the Carnations and green haulms of the Sweet Peas harmonising admirably with the dull greens and blues of the glass. And how far better (and certainly more wholesome) an appetiser are such schemes of decoration on the table, than Angostura bitters or Vermouth, when the tiresome duty of getting down a slice of mutton on a hot day lies heavy upon one.

One mistake-at least such it seems to me - that I often observe, is the eager desire that some people display to pick little sprigs of this, that, and the other flower, wholly unrelated to each other or to any scheme of 
colour, merely because the poor things happen to be out. What possible good to oneself or others can two stunted primroses and a hazel catkin be, stuck in a vase six times too big for them, "because they were out".? If we pick flowers, let us do so with intention. If not, surely it is better to leave them to grow on in the garden or the wood. I do not mean that we should never bring flowers into the house, without thinking hard first whether they will work in with this or that colour. Nothing is more delicious than the haphazard nosegay one gathers bit by bit as one wanders round the garden on a warm Summer evening-here a leaf of Sweet Geranium, there a sprig of Cherry-pie, a specially handsome Carnation, a Rosebud half open, a spire of Mignonette, a spray of white Jessamine, the last new Sweet Pea, a deep winecoloured Viola, a head of Verbena. But such "sweet savours" are for one's own private delectation, for one's dressing-room or writingtable, to bid a fragrant good morning, or to refresh the hours of hard work; and are a 


\section{I96 EVERSLEY GARDENS}

very different matter to the catkin-and-primrose business. In Winter, therefore, for those who do not possess a greenhouse or live near a town where cut flowers can be bought, it seems wiser to give up all such untimely and unsatisfactory efforts, and to depend for decoration on pot plants, or on the bulbs that are so easily grown, till once again

"The hounds of Spring are on Winter's traces."

We may, however, force on the hounds of Spring in a very simple way, which I learnt a few years ago from M. Moser in his famous nursery grounds at Versailles. Flowering shrubs were just beginning to bud; and he told me that if the slender shoots of Prunus Pissardii were cut as soon as the leaf and flower buds began to swell, and put in a vase of water (the water must be plentiful, and should be changed every third day) in a warm room, leaves and flowers would quickly unfold. This I have since done every Spring. Three days after I cut them the buds are generally ready to burst; and a week later each shoot is 
hung with delicate pink blossoms, a lovely sight in bitter March weather. Branches of other flowering shrubs, such as Ribes, Spiræas, Pyrus Japonica, \&c., may be treated in the same way, but none respond so quickly as the Plum.

While Summer is still with us, Roses, Carnations, and Sweet Peas-to mention only a few of our garden delights-make the task of keeping the house gay and fragrant an easy one. But when rains and wind, such as the great September gales of 1903, descend on our unhappy gardens, and warn us that Autumn is here almost before Summer has chosen to bless our labours, decoration becomes far more complicated-I mean for those who cannot command the resources of glass houses. We therefore have often to abandon the easier plan of massing one flower, and to exercise our ingenuity on cunning combinations of the many varieties and tones of white, yellow, and red. The Roses are indeed here, more precious to us than ever in their fragrance and rich colour, if not in their abundance. Sweet Peas survive: but they have lost something of their 


\section{I98 EVERSLEY GARDENS}

glory both in quality and quantity. And the Carnations, save for late plants of the useful Marguerite race, are well-nigh over. Roses are always in harmony with their surroundings, no matter what their colours: but even with Roses a little extra care in arranging them greatly enhances their beauty and effect. For instance, it is better never to mix them with other flowers, unless perchance in some tall jar, where a long spray of Briar Roses will look well in a mass of showy flowers and foliage which represent the mixed border on a small scale. If one indulges in such a mixture, let it be made boldly and whole-heartedly or not at all; for any timidity in decoration is sure to be a failure of the catkin-and-primrose order. But as a rule, Roses should be kept apart from other flowers. If we have only two or three, let them be put in a small glass by themselves; they would be lost among Geraniums and Asters; whereas, if set alone on a table among precious things they make a distinct and telling point in the room. If they are abundant, I would specialise still further, and 
endeavour not to mix Hybrid Perpetuals with Teas; for, although to some this may seem a counsel of perfection, the different races of Roses look their best separate when cut, as they most certainly do when planted.

Roses apart, it is well to keep as far as possible to one scheme of colour in a room. From September to November arrangements of yellow, white, orange, and scarlet are always possible and effective-thanks to the endless varieties now at our command of Helenium, Helianthus, Gaillardia, Pyrethrum, the annual Chrysanthemum, the invaluable hardy border Chrysanthemum, with fiery Montbretias and Gladioli at the end of the scale. But when this is chosen, pinks and crimsons must be rigidly excluded for the moment. On the other hand, we get a lovely alternative scheme in endless combinations of whites, pinks and lavenders; Sweet Peas, China Asters, Ivy-leaf Geraniums, Michaelmas Daisies, pink Gladioli, white Paris Daisies and Japanese Anemones. While the gorgeous Pentstemons, the Nicotianas, and the superbly decorative 
Dahlias, can be used with either group. One of my most favourite combinations for large vases, is a mixture of the tall white Michaelmas Daisy Decima and the rosy-scarlet Larkspur. They seem made to go together in a big strawopal glass jar of Powell's. Another I much affect for the dinner-table is simple enough: white Paris Daisies, the useful pink Ivy-leaf Madame Crousse, and generous sprigs of Sweetleaf Geranium.

Last Autumn one of the most effective of many fine colour schemes made by an artist in words as well as other things, was a daring combination of warm pink and scarlet; and it caused such surprise and delight to a visitor, that when her hostess appeared she could only say: "I never imagined they could go together." It was a mass of the rosy-scarlet Larkspur, pierced through and through with fiery swords of Gladiolus Brenchleyensis. No wonder that the visitor, with a nice sense of art, was found almost speechless before it. The late Michaelmas Daisies, grey, purple, crimson, and pink, if boldly mixed together 
are finely effective. But, like Alexander, they must reign alone; for their colours crush any more clear and delicate ones in a room.

Of the immense value of the early flowering border Chrysanthemums for Autumn decoration, we become more keenly aware each year; for each year shows fresh fine varieties added to the long list. Not only are the white, yellow, bronze, and crimson shades wondrous beautiful; but the new large-flowered Japanese varieties -such, for instance, as Horace Martin among yellows, Goacher's Crimson and Crimson Masse among red-bronze, and scores more-grow so abundantly that a single spray will suffice to fill a jar, lending itself to the most graceful and effective decoration. And even if our flowers fail, when

"The clouds in Autumn crack,"

and the Oaks turn to copper and the Elms to gold, when the copses are full of hazel-nuts, and the passer-by breaks down our fences for blackberries, and the great Agarics glow scarlet under the Fir trees as the russet-coated 
202

\section{EVERSLEY GARDENS}

roe-deer bounds away from the road, the woods and the river's bank furnish us with spoil. For we may bring in branches of the wild Guelder Rose with its graceful growth, handsome foliage, and bright berries. The shorter branchlets with their bunches of scarlet berries make a charming decoration for the dinner-table; for they are nice clean things that last for a week in water, and do not strew the immaculate surface of the linen with berries that stain, or insects that crawl; while the larger branches in tall jars, for the hall or corners of the drawing-room, are most effective. 


\section{CHAPTER XI}

\section{BIRDS AND GARDENS}

While the trees are bare, and before the hedges and shrubs begin to shoot, our bird neighbours, both friends and foes, are much in evidence. And as I love my birds almost as much as my garden, I am always anxious to put in a word for them at this moment, when they are choosing their homes for the season. Indeed, if I was not willing to think about them, my special "wise thrush" is raising his voice in such decided and insistent tones in the Black Poplar just outside the window, that it is impossible not to pay attention to what he says. No human being having lived upon this little bit of land until I built my house here eight years ago, the birds have always looked upon it as sanctuary. And as since my occupation they 


\section{EVERSLEY GARDENS}

have been treated with profound respect, their kindly tradition about the garden remains unbroken; while rare and strange visitants arrive unexpectedly, and, liking the looks of the place, are gracious enough to stay.

"Made before the wind was made," no creatures are more captivating than the birds; and their little ways are endlessly diverting to watch. Each resident bird has his own well-defined beat, and woe to the intruder. There is the front-door robin, the back-door robin, and the orchard robin, who also reigns supreme over the croquet-ground and one Rose bed. The back-door robin takes the eastern hedge from the back-yard down to the kitchen garden, and spends the greater part of his time just now, as his building has not actually begun, in serenading the maids outside the kitchen door. His kingdom joins that of the front-door robin, at the big Rose arch of Rubin and Bennet's Seedling, opposite the dining-room on the north of the house. The front-door robin, my very particular friend (for we hold continual converse through 


\section{BIRDS AND GARDENS}

the study window), takes the south and west of the house with the Rose beds as far as the said arch. But there he meets the eastern king-he did so this morning-and then we see sparks; for more pugnacious, insolent, blood-thirsty little monsters do not exist than these much-belauded birdlings. But when, very rarely, the southern and eastern potentates venture upon the property of the orchard robin, there ensues a three-cornered duel which becomes positively homeric.

With blackbirds and thrushes much the same carefully defined divisions of property are observed. My particularly handsome songthrush friend has possessed himself of the borders and grass on the south and west close to the house, singing in the Black Poplar and nesting in the bushes of the front hedge year after year; and I cannot see that he ever moves far from his little territory (unless chased by an arrogant cock blackbird, who lords it over all the place). His appetite seems insatiable; as from dawn to dusk, unless he is singing, he is quietly and deliberately 


\section{EVERSLEY GARDENS}

at work, searching for worm or grub, and finding them too. I have never yet had the patience to count how many he consumes in half-an-hour: but merely to watch him for a few minutes through field-glasses shows what hundreds of worms and insects a single bird can devour in one day.

And how these poor birds toil for their families in the Summer! The arrogant

"Ouzel cock so black of hue, with orange-tawny bill,"

was sadly put upon by two fully-fledged children last year; and I really was glad of it at first, for his pride needed taking down. They were perfectly capable of getting their own living; and if the exhausted parent found nothing, these fat, speckled young rogues would work on their own account behind his back. But no sooner did he acquire a good long worm for his own breakfast, than both his offspring with loud cries, gaping beaks, and quivering, trailing wings, took on starving baby manners, and he had to yield it up, in bits, to their importunities. One 


\section{BIRDS AND GARDENS}

day, however, when his glossy coat was all rough and worn, the end of this nonsense came. The burden was as intolerable as it was unnecessary; his naturally overbearing character reasserted itself; and, turning on the lusty young humbugs, he pecked them so soundly that they took the warning and supported themselves thenceforth.

As I allow no gun or trap on the place, the blackbirds and thrushes, despite a few untimely deaths at the hands of the cats, have it pretty much their own way in the garden. And if they do take a few Strawberries where the nets lie flat round the edges of the beds, well, they are welcome; for I have enough and to spare. They are sadly cunning, I confess, in creeping under the netting over the Raspberry bed: but even there I hope to circumvent them this year. Their worst crime is in the matter of cherries; for they will strip a tree faster than ever did Jean-Jacques for Mlle. de Graffenried and Claudine Galley on the famous "journée de Thoune." 
Of course the soft-billed birds-the "hedgepoke" as our Hampshire boys call the hedgesparrow, the wren, the white-throats, the garden warbler, the black-cap, the flycatchers, willow-wren, and chiff-chaff-are invaluable in the garden, and do nothing but good. To see a tiny chiff-chaff going through a Rose bush, searching every shoot and leaf above and below for grubs and aphides, is a pleasant sight to the gardener and the naturalist; for the quick, dainty movements of the

$$
\text { "tiny browny bird from out the south" }
$$

are as charming as its work is useful. And the little brown "Kitty-wrens" who build in the haystack, are just as diligent, especially in the climbing Roses on the house. But despite the outcry against the tits, especially the blue tit, I strongly incline to the view that the supposed harm he does to fruit buds is hugely over-rated, and far more than counter-balanced by the innumerable insects he destroys. A pair of blue tits frequent my Rose beds all the winter. I have watched 


\section{BIRDS AND GARDENS}

them working over every twig in the most thorough way, and certainly not a Rose bud has been hurt; while they have been much too busy to attack the fruit trees. I am rather blessed here in the matter of tits, so that I can speak from experience. The blue tit, cole tit, ox-eye, and that most exquisite bird the long-tailed tit, frequent the garden. And the latter is one of our greatest benefactors; for he will find and eat the most minute insects that lodge in the cracks of the bark or behind the buds, and uses the silk of caterpillar cocoons for his exquisitely built nest. A pair of long-tailed tits did me the honour of building in a furze bush last Spring just outside my stables. And it was a real treat to be able to observe the lovely little pair closely. When the young were hatched, I watched the parent birds feeding them at the rate of an insect every two minutes. But a tragedy took place. A tremendous thunderstorm washed the nest, heavy with the growing brood, out of the furze bush, and my gardener found it on the ground with 
the mother bird sitting on it. He managed to put it back, and the feeding went on as usual for a few days; but after a second storm and a second fall the birds disappeared -and I greatly fear the young must have been devoured by the stable cat, though the parents are still safe and sound and by no means disposed to leave the scene of their misfortune.

The handsome stone-chat is also a sworn foe to insects. A few winters ago I got a neighbouring farmer to fold his sheep on my newly-laid croquet-ground; and a stonechat instantly took possession of the hurdles, perching on them for a moment only to fly down the next and seize some invisible prey with the pretty dipping motion that distinguishes his flight, and then returning to his post. The brilliant little bird seemed to have solved the problem of perpetual motion, so rapid and ceaseless were his excursions.

The great green woodpecker, who builds in an old Oak tree near by, is also a frequent and useful visitor, especially in snowy weather, 


\section{BIRDS AND GARDENS}

when he spends hours digging his long beak into a bit of rough grass in the garden, and alarming the starlings who stand in great awe of him. Even the blackbird treats him with respect and keeps at a distance.

The covey of partridges that are always to be found in one of my meadows, often make their way up to the garden in the early Summer mornings. And one hard Winter the charming creatures came up over the snow close to the house in search of food, terrifying one of my young cats, who had never before seen such large birds, to such an extent that he hurled himself crying loudly for shelter, against the French windows of the dining-room, while the partridges remained perfectly calm. When birds feel quite secure, their ways with cats are very entertaining. Puschkin and Gogol, when they were kittens, used to be much worried on Summer evenings by the mysterious Fernowls (Caprimulgus Europaus). One would fly silently down the garden and perch a few yards ahead of the cats on the path; while 
the other, on those broad wings that seem to be made of cobwebs rather than of feathers, would sweep softly and swiftly over the heads of the wretched, bewildered kittens, till they ran anywhere for safety from such strange elusive foes. Swallows, too, love to torment cats; and I have even seen them dip and tweak a cat's ear if it was walking below their nest.

A very fierce and aggressive pair of visitors arrived four Summers ago in the garden, and were warmly welcomed; for they had not been seen round here for several years-the redbacked Shrike, or Butcher-bird. A bold and noble fellow he is, fearing neither man nor cat, as I found to my cost on hot July days when I tried to get a little rest in the shade. For no sooner had I settled down with book and paper, than the ancient Gogol-not the poet, but the cat-joined me; and then arrived both the shrikes. Furious at the unpleasing sight, they perched on the boughs almost within reach of my hand, flirting their tails from side to side, and uttering such harsh, discordant 
cries of rage that my head spun, and at last I had to beat an ignominious retreat into the house. Two of the greatest English ornithologists paid me a visit that August in hopes of seeing the shrikes and their four fierce young ones, who, as soon as they were fledged, joined their parents daily in the horrid catscaring din. But they had already taken flight for their long journey to the Soudan, or perhaps to Rhodesia where they sometimes winter -a journey that must have been a successful one, for the next May saw them arrive, and perch, rather tired, on the very same bough on which I had first espied them. One of my visitors, however, extracted the old nest from a Bramble brake in the hedge, and this bore testimony to the value of these fine birds in the garden, as it was full of wing coverts and débris of quite large beetles, \&c.

So much for garden friends. As for foes, I only count three. Alas! one of the three is the beautiful bullfinch. It goes sorely against me to make this confession. But only last Spring I watched a hen-bullfinch calmly take 
possession of a Damson tree which was thickly set with fruit buds. It was while I was dressing, and the gardener had gone home for his breakfast; and though I shouted and clapped my hands from the window, the plump little marauder remained perfectly calm. So all that I could do was to watch her through my fieldglasses. But for the sense of loss of all my damsons, it was interesting to see her methodical work. She started from the tip of a branch, and picked out every bud the whole way down it. Then she took the next-and by the time I got down to the tree an hour later, not more than a dozen flower buds were left untouched. My neighbour the wheelwright, who is a keen and observant naturalist, was lamenting only last week that the usual pair of bullfinches had arrived in his garden, and had already stripped every one of his gooseberry bushes. And, as they generally come to my garden next, I am going to try whether Bordeaux mixture, or quassia and paraffin, sprayed over the trees, will save my unlucky fruit buds this year. The cock-bird, 


\section{BIRDS AND GARDENS}

I regret to say, arrived this morning to reconnoitre: but the garden boy pelted him with stones, and he departed for a time.

The second on my Index is the handsome and cruel jay - a foe to other birds; for have I not seen a nest of nearly fledged young blackbirds destroyed by him-each poor birdling split open as if with a knife, and only its heart eaten by its barbarous enemy. But the sparrow-that dirty, impudent, vulgar, thieving ruffian of the garden-he is the real foe; and for him I have no pity. It is he_- "the Avian rat" as that great and wise woman, Eleanor Ormerod, called him-it is he who evicts my house-martins, and drives them from the nests above my window year after year, just as they are finished. It is he who tears every Crocus to pieces, who nips the heads off the Polyanthus, who eats the Peas, who-but I will stop, for long is the list of his iniquities. He carries his low manners and customs with him wherever he goes, so that his name has become a by-word among the natives of India. He has turned into a very scourge to the good, 


\section{I 6 EVERSLEY GARDENS}

trustful folk who imported him and built charming houses for him in the trees in Boston, in order to replace the indigenous birds that civilisation had destroyed; while in this part of England he is becoming so serious a pest to gardener and farmer alike, that sparrow-clubs are being revived, and I am hard-hearted enough to wish them success.

But despite all the help that friendly birds can give us, May and June always bring what a small schoolboy-now a distinguished statesman-described in his lesson on the plagues of Egypt as "cadhoppers and grasserpillars inumerable." For the pest of creeping, crawling, flying things is then upon us; or unless measures can be taken in good time, the first bloom of our roses is sadly marred. As regards the fat brown grub that burrows into the heart of each tender shoot, and sticks the leaves so firmly together that no insecticide can penetrate his fastness, there is, I believe, no remedy save hand-picking, and sickening work it is; for he is both soft and lively, and needs careful handling lest one should either 


\section{BIRDS AND GARDENS}

squash him or let him escape. The hard green caterpillar found on the under side of the leaves, is not so unpleasant, as he at all events is clean and dry and slow, and can be picked off neatly and thrown on the grass or the gravel walk for the hard-worked parent thrush, who slaves early and late to satisfy his nestlings among the Roses outside my bedroom. But chiefly do I loathe a small, greenish-grey wretch with a black head, and an even more vile creature that leaps and twists like a trout on the hook; for these are both soft and slimy and easily squashed. Instead therefore of rejoicing in the divine beauty of the burst of early Summer, the unhappy Rosegrower too often wanders about with eyes and mind fixed on the curled leaves, the glued and twisted shoots, that denote grubs. A thunderstorm, far from annoying, seems only to refresh them, and to render their appetites more cheerfully voracious. And even constant syringing fails sometimes to check them. For some years I used the excellent mixture advised by my old friend Mr. Alfred Perkins, of Coventry. 
Boil four ounces of quassia chips in a gallon of soft water, strain it, and while cooling dissolve in it four ounces of soft soap, and add three gallons of water. But last Spring, thanks to east wind, dry weather, and hot sun, the plague of green-fly and all kinds of grubs was particularly bad round here, and I was in despair; for even this excellent recipe, to say nothing of aphis-brushes and fingers, failed. Then hope came. On the advice of various friends who swear by it, I tried Abol. Would that I had done so sooner. The climbing Roses on the house were fairly smothered with aphides and sundry minor plagues; and one light syringing of Abol cleared them at once; while a second application a fortnight or three weeks later cleansed the young shoots which had sprouted meanwhile, and settled the matter. It also proved a remedy for the small soft greenish-grey grubs; for if it does not actually kill them, it makes them so very sick they have not much strength left for mischief.

I cannot say that Abol is fragrant: but the 


\section{BIRDS AND GARDENS}

rather acrid smell goes off in twenty-four hours; and of course no one would dream of applying it to Roses in full bloom that are intended for cutting. Not that it does them harm, for it will not injure the tenderest leaves or buds, or stain the hands.

I have also used it with perfect success for black-fly on pot Chrysanthemums; and a neighbour last year found it most useful in early Spring for spraying gooseberry and currant bushes when the buds were swelling, as the birds did not touch them afterwards. ${ }^{1}$

Yet really these plagues of Egypt, both creeping and flying, are a sore trial to the poor Rosarian even with the help of Abol and the admirable "Abol Syringe." And in times of depression one feels inclined to cultivate only such flowers as are exempt from grubs and blight; Pœonies for instance, or Rhododendrons. Alas! that they are such a shortlived joy; for where should we be in July without our Roses.

1 Since writing this I have used Abol on fruit trees and bushes with complete success. 


\section{CHAPTER XII}

THE AUTUMN GARDEN

$\grave{A}$ quelques choses malheur est bon. It is not until we have been obliged perforce to spend long weeks in or about the house, with no change of scene beyond a feeble prowl round the garden, that we discover how much of our enjoyment or discomfort depends on the planting and general disposition of that same garden. When for a time it constitutes the limit of our horizon, we grow quick to see where schemes have failed, or where success or happy accident has crowned them, producing such harmonies of line and colour as may give repose and healing calm to tired nerves and brain. And these failures or successes are specially evident in Autumn. In Spring and Summer the riot of colour, the beauty of each individual flower, is joy enough in itself to 


\section{THE AUTUMN GARDEN}

distract our attention from the broader effects of trees and shrubs, which should be so disposed as to produce the harmonious whole. But when flowers are well-nigh over,

"And fruit and leaf are as gold and fire, And the oat is heard above the lyre, And the hoof èd heel of a Satyr crushes The chestnut husk at the chestnut root,"

then how all-important do our plantings and groupings become. Here, for instance, are my notes one day in an Autumn not long ago, which taught me, among certain other things which have little to do perhaps with gardencraft, how much may be done with the minimum of expense, by trees and shrubs planted for colour effect; for every leaf of every tree and bush was singularly vivid.

"A Prunus Pissardii seen against the bronze green of a mighty oak and the warm yellow of the 'Turn of the road,' has been gradually transformed from its Summer garb of purplebrown into a pyramid of glowing crimson, each day adding a fresh touch to the richness of its colour. Near by, in the Spiræa bed at the 
bottom of the garden, the long delicate shoots of $S$. prunifolia, whose praises I never weary of singing, have been a delight for the last three weeks, and, despite frost, rain and tempest, are still enchanting. The exquisite blue-green Summer foliage has changed through those indescribable shades of green and purple one sees on the lustrous breast of the proud Venetian pigeons that roost along the cornice of St. Mark's. And the purple in its turn has been driven upwards and outwards by crimson and yellow, which have slowly and stealthily transformed the heart of the bush to actual flame-colour, the points of the shoots still shot with purple which makes them look in the sunshine like a mist of amethyst. Its beauty is further enhanced by the lucky accident of a big plant of a very late, deep purple Michaelmas Daisy right behind it in another border, and by the gold of its handsome relation, $S$. opulifolia aurea, by its side.

"To another happy accident is also due one of the prettiest effects in the long border under the hedge-that wild hedge of tall Furze and 


\section{THE AUTUMN GARDEN 223}

Broom, Bramble and Briar Rose, that forms my delightful barrier from the passer-by on the high-road. Against the many tones of the dark green background, one great cherrycoloured Rose has lifted its head on a long shoot high above the drooping orange and scarlet plumes of a low Sumach, which appeared, I know not whence or how, among the Rhododendrons; and the group is completed by the brilliant crimson of a sturdy Azalea, the colour of its foliage repeated in a haze of WildRose hips up among the Broom and Gorse. Nearer by in the same border, above the cold glaucous-grey foliage of a line of the invaluable Mrs. Sinkins pink, a pure white Aimée Vibert Rose stretches far out of the dark hedge above white Japanese Anemones and a pink Marie Masse Chrysanthemum; while up aloft, scarlet trails of Virginia Creeper hang from the tall young Lime tree into which they have climbed."

What would our English Autumns be without those glorious red wreaths of Virginia Creeper; or the close-tiled sheets of its more 


\section{EVERSLEY GARDENS}

modern cousin, Ampelopsis Veitchii. But why do we not more frequently use the former as I have seen it grown in its native land, as a ground creeper? A more exquisite colour effect is hard to find than its vivid wreaths trailing where they will over pale grey rocks by the lake in Central Park, New York. .The Sumach, growing wild up an American hillside, is a far better plant to look on than in the English garden, where Autumn rains too of ten spoil its foliage before it has had a chance to come to its intense colour. But the Venetian Sumach, Rhus Cotinus, is a very beautiful object in the Autumn garden; and, with its round leaves and feathery seed-vessels, I prefer it infinitely to its more gaudy transatlantic cousin. In the famous garden of Great Barton, in which that distinguished botanist and truest of friends, Sir Charles Bunbury, carried on the work begun in the arboretum by his father Sir Henry, the great bushes of Rhus Cotinus were a marked feature at this time of the year; while the Pomegranate and Myrtle against the house were still in flower 


\section{THE AUTUMN GARDEN 225}

round the windows of the long, low breakfastroom, as though they would set a rare frame for Sir Joshua Reynolds' yet rarer portraits within, and do honour to the brilliant talk that went on round the breakfast-table.

I often wonder why certain of our fruit trees are not more generally used in so-called ornamental planting, instead of being sternly relegated to the kitchen garden or the orchard. They would fulfil the purpose of their being every whit as well, while giving delight to the eye in Spring and Autumn. Some of the Pears -not all-take on gorgeous colouring in the fall of the year, as a journey through the fair Vale of Evesham demonstrates; their long upright shoots rising like glowing torches of deep crimson, copper, and orange-pink among the more sober greens of the orchards with almost startling effect. A Beurré d'Amanlis and Pitmaston Duchesse d'Angoulême have given me weeks of as great pleasure lately, as did the all too short days of delight in their snowy Spring blossoms. And over a young tree of Worcester Pearmain, set thick with scarlet apples at the end 


\section{EVERSLEY GARDENS}

of August, two friends waxed so enthusiastic, that they settled then and there to give each other a tree of it as the most charming offering that friendship could devise. What in the Autumn world can be more attractive than a well-fruited tree of the dear old Red Quarrenden, such as one that grew in the Rectory garden? and how we loved it when we ran out between lessons and begged one of its apples from George Chaplin to eat with our bit of cake. Crabs, too, are as ornamental to the Autumn as they are decorative for the Spring garden; especially such kinds as Fohn Downie, with rich red fruit, Fairy Apple, red and yellow, Dartmouth, crimson with a purple bloom over the fruit, the scarlet Paul's Imperial, and the Siberian Scarlet and Siberian Yellow.

Then, again, few Autumn bushes are more ornamental than a Medlar. I got one a few years ago simply for the sake of its foliage, and it has proved a thing of beauty every Autumn; while its effect this year was intensified by a plant of Rosa Alpina-a sucker from the stock of some Tea Rose it has killed 


\section{THE AUTUMN GARDEN}

-which shot up seven or eight feet through the Medlar's branches, and there turned to flaming gold and red. Needless to say, because I loathe the quaint little Medlars, no other fruit tree in the garden bears such crops. Happily, however, a neighbour has been discovered who thinks the little horrors a great dainty, and is positively grateful to me for bestowing them on her.

Of Japanese Maples, all are beautiful, all are decorative, from early Spring to late Autumn; and as they are perfectly hardy we cannot grow too many of them in the garden. But to be seen to the greatest advantage they must not be huddled in with other shrubs, but planted singly or in groups, with plenty of space between the bushes, in some position where their beauty may be seen from all points. A huge bush of $A$. palmatum atropurpureum, standing out alone in the centre of one of the Rhododendron dells in Mr. Waterer's garden at Bagshot, was so striking an object as to distract one's attention for awhile from the lofty walls of blossom round it. And if its 
colour was vivid in June, one knew it would be twice as intense in October.

But some of our native shrubs are not to be despised. The long shoots of the Guelder Rose of the garden, and its wild cousin from the woods, are deep in colour now-and the latter is yet further decked with bunches of scarlet berries. The pretty Spindle Tree (Euonymus Europaus) of our hedgerows is covered with a fringe of pink coral above the rich purples and reds of Bramble leaves; and the crimson clouds of Wild Rose and Sweet-briar fruit in every hedge, shine brilliantly against the blue misty distance. But the greedy blackbirds and a flock of missel thrushes, showing a taste for imported as against home-grown products, discovered the delights of the handsome berries of Rosa Rugosa early in the season, and have stripped every bush bare, long before hunger could be pleaded as an excuse.

Enough, however, of shrubs; for there is one tree (among many others) that no Autumn garden should be without - the common Balsam 


\section{THE AUTUMN GARDEN}

Poplar. Each year I watch mine with intense enjoyment; and see how from the heart of the tree the colour spreads out along each branch, slowly, stealthily, without violence, while the ends of the shoots remain a vivid green as of emeralds on golden boughs, until at length the whole tree glows in a garb of exquisite pale gold. It is interesting to observe that the Norway Maple exactly reverses the process, the tips of the branches turning golden first, and the colour spreading inwards. One warm, misty morning, while the fog still hung thick over Finchampstead Ridges across the valley, the sun suddenly flashed out upon a huge group of Balsam Poplars a quarter of a mile away down by the river. The effect of the clear gold against the thick grey Ridges was so astonishing that, longing for sympathy, I cried to an old friend who was hedging and ditching for me, "Look, L__, look at the golden trees!" He did look; remarking calmly with a kind of indulgent forbearance, "They be the paupler trees down athirt the medders," and went on with his work. 


\section{EVERSLEY GARDENS}

With Lilies and Gladioli, Dahlias and Lobelias, Pentstemons, Heleniums, Michaelmas Daisies, and the invaluable border Chrysanthemums, the Autumn flower garden may be kept brilliant till well into November, if we have decent luck as to early frosts. But of one matchless annual I must sing the praises for Autumn as well as for Summer-I mean Sutton's Rosy-Scarlet Stockflowered Larkspur. It is in bloom from the beginning of July. I cut armsful of it for the house, and for many other houses, all through the Summer and early Autumn; and some small late-planted seedlings, dragged up by the roots and put bodily in water at the end of last November-for it was imperative they should be cleared away to make room for Spring bedding-made the rooms gay for another week. As nearly every one who comes to the house asks me "What can that lovely thing be?" I can only suppose it is not as universally known as it should be; one of its many merits being that it lasts a good ten days or fortnight in water. By itself, or combined with the tall, pure white 



\section{THE AUTUMN GARDEN 23I}

Michaelmas Daisy, it is the perfection of a decorative flower for tall vases.

Among the newer developments of perennials, few are more striking than the work of the hybridizer in Pentstemons and Lobelia Cardinalis. The varieties of colour in both are as surprising as they are beautiful. And although I never hope to see in England the intense cerulean blue of $P$. Faffrayanus and Brandegei as they grow on the dry plains at the foot of Pike's Peak-for here they get too much moisture and too little sun-yet hybrid Pentstemons sown in heat in February and flowering the same year are by no means to be despised. A long row of them in the Garden of Delight last year displayed every conceivable shade of pale pink, rose, crimson, mauve and strange lurid purple. The hybrids of Lobelia Cardinalis were even more striking, planted in separate groups beside the grass paths in the Water Garden, as may be seen in Mr. Townshend's photograph of Hydrangea paniculata. Many of these beautiful varieties are raised from seed saved on the spot, besides other named sorts. 


\section{EVERSLEY GARDENS}

And the tall spikes, from delicate rose to deepest crimson and vivid scarlet, rising out of the damp grass with foliage as varied in tones of green to metallic red, added a fresh touch of splendour to that wondrous garden. How far have these amazing descendants travelled from the dear old $L$. Cardinalis one remembers growing along the ditches in northern New York State, among Golden Rod and Michaelmas Daisies in early October! But splendid as these hybrids are, none are more startling in colour than the parent.

The good old grey-lilac Michaelmas Daisy of our youth, the colour of ancient lilac print frocks, and beloved of Red Admiral and Peacock butterflies, and of slow dull drones, is now superseded by such endless varieties, white, purple, pink, or crimson, that it is almost impossible to say which one has or has not got in the garden. But late or early, tall or dwarf, they are delightful and useful flowers. And a row of them with Pyrethrum uliginosum and a few good Heleniums at intervals, make a solid and brilliant screen 
in front of the humble Cabbage or Potato below the north hedge here. They also enable one to give one's friends pleasure; for their growth is so prodigious that they must be divided every second year at least, or the clumps would grow too big. And thus they afford us an excellent opportunity of practising the Chester Sunday-school child's definition of Charity- " giving to your neighbour what you don't want yourself."

But let us use Michaelmas Daisies as Nature uses them; grouped with other plants which enhance their beauty - with plants, too, which flower before they come into bloom. For nothing is more dismal than a "collection" of Michaelmas Daisies, such as I once saw in a garden that rather piques itself on being the last word of what should be. A choice collection they certainly were. Yet, planted without any relief in two wide borders on either side of a rather narrow path, their effect before they were fully out was so utterly depressing and really ugly, that I nearly vowed on the spot never to look at 
one again. But when I remembered one October morning years ago at West Point, when the mountains along the Hudson River were all ablaze with scarlet, crimson, and yellow, and the feet of the cadets on their way to Sunday chapel brushed through a mist of dwarf mauve "Asters" on the parade ground, I repented me of my impatience at the misuse of so delightful a plant. Mercifully Mother Nature never plants "collections," and surely she knows best; and it is therefore well to follow her guidance. A mass of mauve and purple Michaelmas Daisies as background to a bold group of Red-hot Pokers, forms a most striking point in the Autumn garden; especially if they can be so placed as to have a further background of dark hedge, wood, or evergreens. And the many charming white varieties - the tall, graceful, branching Decima or some kindred sort, with the delicate Ericoides and tiny heath-like multiflorus-can be used in a score of ways in beds or borders so planted as to carry out delightful colour schemes from 
April to December. These three, for instance, plentifully interplanted with my best of annuals, Sutton's Rosy-Scarlet Larkspur, or, if stronger colour is desired, with Lobelia Cardinalis, make a perfect Autumn bed; and, until the Daisies are in flower a grounding of pale mauve or wine-red Violas, with a carefully selected succession of Daffodils, late Tulips, and Lilies, will keep it bright from April.

I have long dreamt of a large round bed which shall give colour to my garden from early Spring to latest Autumn. It is to be made three feet deep, of brown turfy loam, leaf-mould, and peat. The scheme of colour is chiefly red and white. For permanent tenants it has a central group of Hydrangea paniculata, surrounded by a dozen Azaleas, enchanting fiery Mollis and others, in shades of red, flame, and deep orange; the Hydrangeas furnishing huge white panicles from Summer to Autumn, the Azaleas flaming blossoms in Spring, and deep red and purple foliage in Autumn. The ground beneath is 
covered all over with a thick carpet of single and double Anemone nemorosa, and the heavenly blue of $A$. blanda and Apennina, while an edging of $A$. fulgens will girdle the whole, if only the dear capricious creature can be persuaded to grow. Out of this grounding rise bulbs among the permanent plants; plenty of the early Gladioli, The Bride for pure white, Delicatissima and others for pink and red. These are followed, when the Hydrangeas are in their glory, by the scarlet of G. Brenchleyensis and flame-coloured hybrids of Gandavensis, with Hyacinthus Candicans and the intense red flower spikes and deep rich foliage of Lobelia Cardinalis. While deep in the peat and loam and leaf-mould of that bed I will plant Lilium Auratum, in the fond hope that it may flourish here undisturbed, as it did in my dear old friend G. F. Wilson's wonderful garden at Wisley, ${ }^{1}$ and, rising through the gorgeous foliage of the Azaleas, will crown the whole composition with its splendour.

1 Now, thanks to the generosity of Sir Trevor Lawrence, in the possession of the Royal Horticultural Society. 


\title{
CHAPTER XIII
}

\author{
BRAMSHILL
}

Whether Bramshill is more beautiful in Summer than in Winter is a question I have asked myself ever since I began to realise what beauty of park, of garden, of farstretching view, of noble building meantever since I began dimly to understand the delight of living close to one of the most stately houses of the English Renaissance.

A peculiar charm hangs about the great country houses of the Elizabethan period. The castles belong to a totally different condition of things and people, to a ruder, fiercer, less civilised time. Their towers and walls, where the jackdaws build in the ivy; their moats, where hoary carp bask and fatten; their drawbridges, heavy doors, and loop-holed windows, all tell of unrest-of the semi-warlike state of feudal days, when each great seigneur 
was a petty king in his own county, with his private as well as national feuds, and his little army of retainers and men-at-arms ready to do his bidding, whether to fare forth in service of the king, or to defend his own walls against some powerful neighbour.

But the houses of the English Renaissance tell us of the new order of things - of England in her golden age. The walls of mellow red brick, frosted with grey and gold of lichen; the rows of wide stone-mullioned windows and hanging oriels; the delicate, fanciful chimneys rising in great clusters above the pointed gables and the finely-carved parapet; the broad stone steps leading up to the arcaded hospitable door ; the smooth green terraces, bowling greens and gardens, walled in it is true, but with walls that are covered by fruit trees and Roses, and closed with gates of curiously wrought ironwork, meant more for ornament than defence -all these speak to us of the great awakening, of the desire to make life more beautiful, more perfect, which had spread to England from Italy and France during the sixteenth century. Men now began to think of their homes not 
as strongholds to repel or enforce aggression, but as caskets in which to enshrine those gentler arts and tastes in life and living, which peace at home and influences from without were fostering. 'The casket must therefore be worthy of that which it contained-the treasures of art and literature, the wonders of the new world and the old. Pictures, statues, jewels, rich tapestries, precious marbles, rare furniture, porcelain from "far Cathay," and books. For English literature, all but dead through the storm of the Reformation, had come to life, and a galaxy of poets such as the world has seldom known, was turning England into "a nest of singing birds." And thus it came to pass that through the length and breadth of the land those stately mansions of the late sixteenth and early seventeenth centuries sprang into being.

The very position of Bramshill singles it out among these noble Jacobean mansions. For instead of being set, like too many of them, down in a hole, it stands magnificently on a promontory of the park, the ground falling sharply away south and west to the 
Broadwater in the valley. Bramshill was begun by James $\mathrm{I}$. in the year of his accession ( 1603 ), as a hunting lodge for Prince Henry, upon the site of an ancient manor house. And on the death of that promising young prince in 1616 , the King sold it to Lord Zouch, who finished the building some three years later. From the Zouches it passed to the Henleys. And in 1695 it became the property of the Copes, its present owners. But while Lord Zouch's statue stands high in the centre of the beautiful east or garden front, above the long gallery, James I. has left his mark upon Bramshill in more ways than one. For in the finely pierced carved stone parapet that runs round the roof, the three plumes of the Prince of Wales' feathers form the central ornament of the splendid west front, over the hanging oriel window of the chapel-room above the main entrance. And the matchless Scotch Firs of the park, together with the isolated clumps at Elvetham, and on Hartford-bridge Flats, were planted by the King, as in all other places he inhabited or visited, in memory of his northern kingdom-those at Eversley 


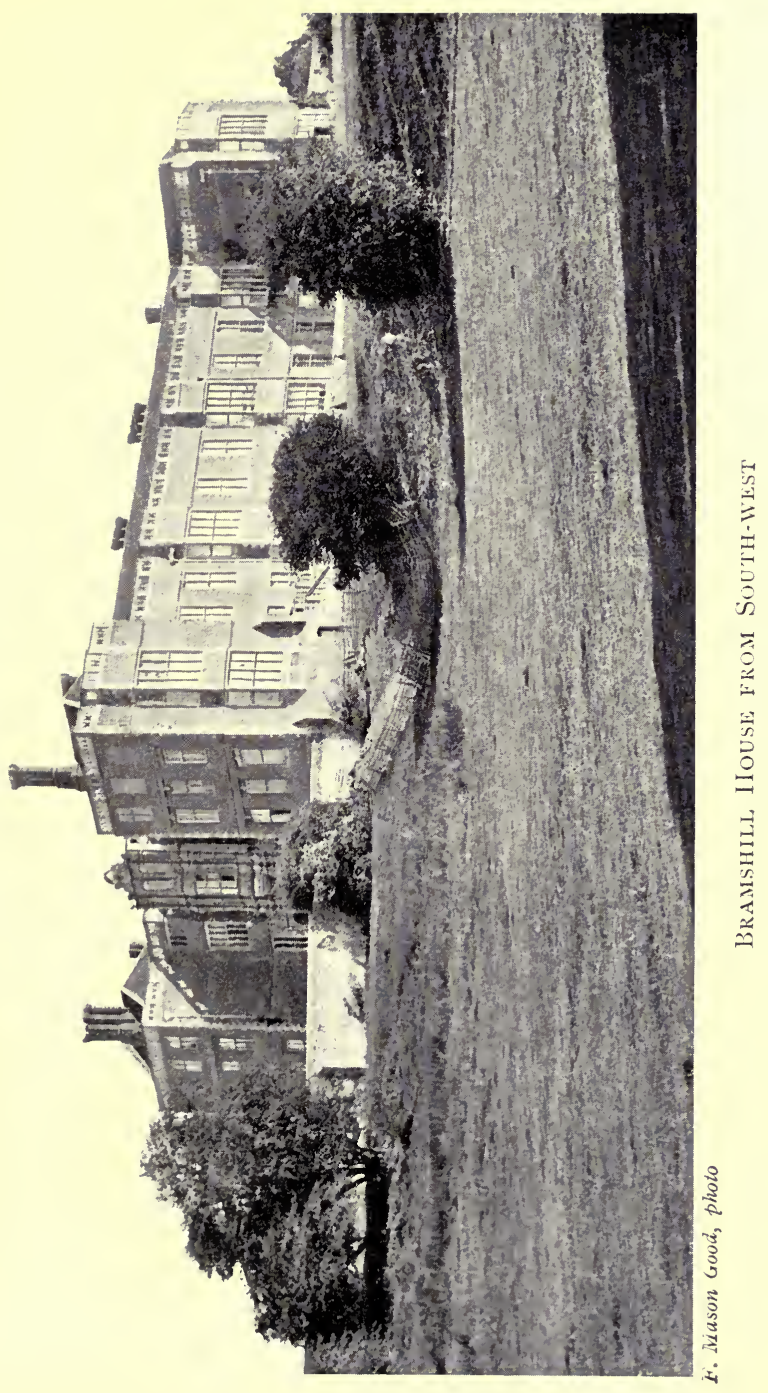



Rectory being of the same date. The hardy trees took kindly to their new home; and, seeding themselves, have spread far and wide over vast tracts of the country round, turning the bleak, heather-clad land into forest once again. Nowhere south of Tweed are finer specimens to be found than in this Hampshire park. Of the original trees, an avenue runs round a triangular space of the park some quarter of a mile across; while other gigantic specimens alternate with huge Silver Firs, rising from Bracken and Heather on each side of the principal avenue leading from the house towards Eversley, this merging outside the confines of the park into a superb Fir avenue of younger trees, which would be considered giants if their ancient progenitors were not seen. One side, unhappily, of this latter avenue has been sadly marred by a succession of fires, the bane of our beautiful moorlands. But so rapidly do these trees grow, that one trusts another fifty years may see the Fir avenue restored to its original estate, an arcade of lofty shafts, red in the sunshine, meeting overhead in a canopy of dark green, and 
carpeted beneath with the pink and madder brown of deep Heather.

Many are the avenues at Bramshill. A sevenfold one of Oaks leads out of the park on the north beyond the lake. And from the west front, a double avenue of gigantic Elms leads down the rapid slope to the Broadwater that gleams silver beneath the bridge, and up again to the limits of the park and the heather-clad moorland of Hazely Heath a mile away. Up this avenue, in the early days of Bramshill House, the deer were driven to be killed at the ladies' feet below the parapet between two pepper-box towers, which stand sentinel at the end of the low brick walls enclosing the great fore-court of smooth green turf and golden gravel, which lies in front of the main entrance. A noble view is that from the house, as the eye ranges south and west over the rich and varied masses of trees to the far horizon, from the Beacon Hill and Cæsar's Camp above Aldershot, to the distant blue line of the chalk downs from Basingstoke to Highclere and Kingsclere over Newbury. While from the east front the confines of Windsor Forest 


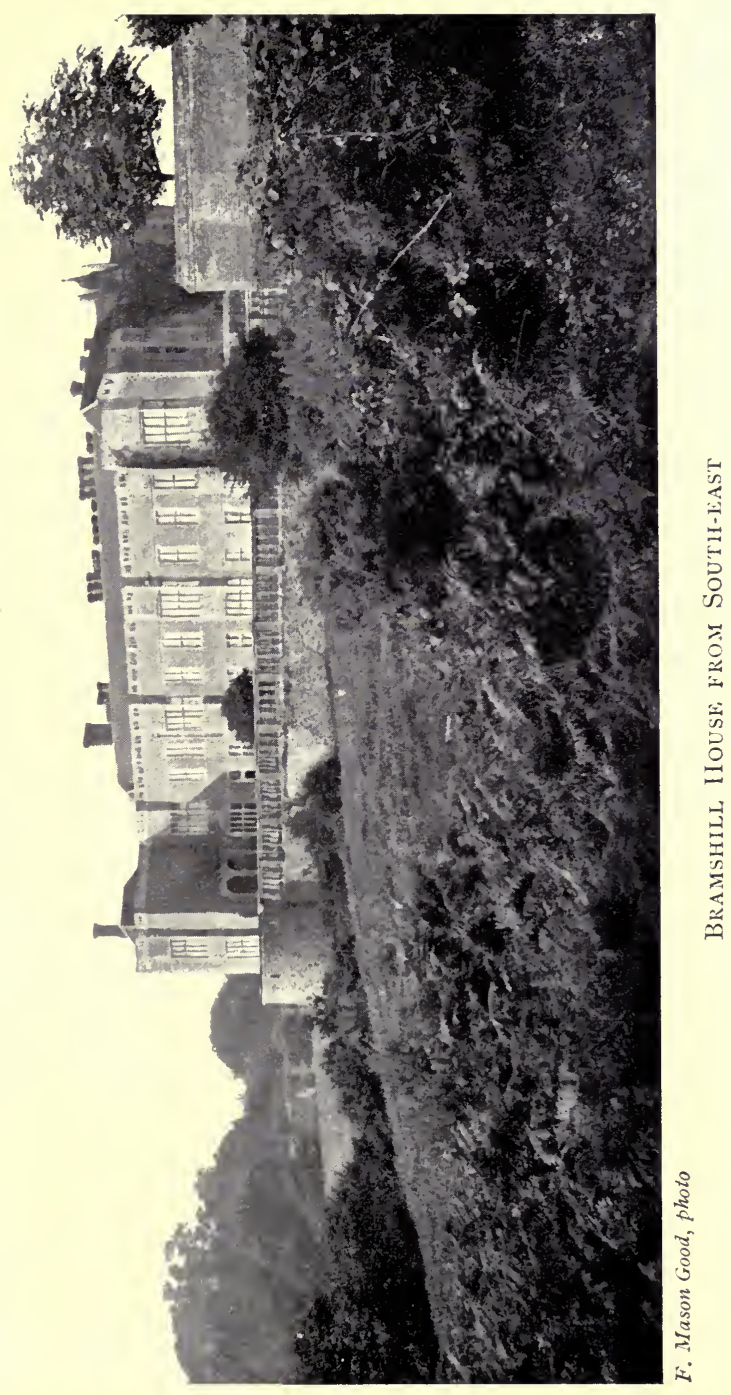

กั
ก

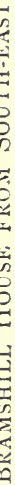



appear over the greensward of the cricket ground, through the vista of yet another avenue of huge Beeches, recently rediscovered and cleared.

How enchanting a Summer's day is at Bramshill as one paces the terrace that lies in deep shadow along the south front, between the two arcaded garden halls at each end under the projecting wings of the house. The scent of sun-baked wild Thyme and Heather fills the air, and mingles with that of the Musk that comes up through every interstice of the paved pathway under the windows of the lower staterooms, and of Sweet-briar growing below the terrace wall. As we pass through the arcade at the east end, and emerge by an arched doorway on to the troco ground, we may still see the wooden balls and long iron-cupped poles with which the lords and ladies of King James's day played troco; and in the centre of the turf, smooth as a billiard-table, the iron ring through which they pushed the heavy balls still stands. How the Roses grow on the walls that shelter the troco ground from north and east. A big plant of Grace Darling is in full flower some 


\section{EVERSLEY GARDENS}

three weeks before mine are, down in the low land of Eversley. And in one corner there used to be a huge bush of the double yellow Persian Briar, of prodigious size and age. In our childhood, tradition used to say that it had been brought from Damascus a hundred years before; and the size of its knotted stem made for belief in the tradition. Certainly there never grew a sweeter Rose, or one more worthy to blow "along the river brink, with old Khayyám," in the far gardens of the East. Many hundreds of blossoms I have gathered, and gather still, from its descendants. For it was the parent of a hardy tribe, each sucker growing and thriving in the poorest soil; and during June every cottage garden in the parish is glorified by a wealth of their golden blossoms.

Whether Bacon ever visited Bramshill is not known: but as one looks at the house from the troco ground, one cannot but think its builder must have profited by the essay on building in designing its stairs "upon a fair and open newel," its " embowed windows . . . for they be pretty retiring places for conference, and, besides, they keep both the wind and sun off." 
While the great hall, or the magnificent staterooms with their mantelpieces of Italian marbles, running up to the exquisite ceilings covered with intricate mouldings and pendant bosses of marvellous workmanship, their fine tapestries, their rich furniture, which forms a complete history of English furniture from the Elizabethan to the Victorian period, follow his precepts closely that "you cannot have a perfect palace unless you have two several sides; . . . the one for feasts and triumphs, and the other for dwelling." Still more is the "royal ordering of gardens" brought to our minds, as we wander through an archway leading from the troco ground to the square walled garden on the east front, its walls draped with Climbing Roses, Wistaria, and Honeysuckle, and the borders beneath them ablaze with colour. It would be difficult for any modern gardener to improve on the great philosopher's scheme for "gardens for all the months in the year, in which, severally, things of beauty may be then in season;" or on his suggestions as to the sweet-scented flowers to plant about a house. Of the Musk Rose and the Sweet-briar there is no lack at 


\section{EVERSLEY GARDENS}

Bramshill; or of the "Wallflowers, which are very delightful to be set under a parlour or lower chamber window. Then Pinks and Gilliflowers, especially the matted Pink and clove Gilliflower. . . . Then the Honeysuckles, so they be somewhat afar off." Another flower is planted with no sparing hand round Bramshill; for in the days of its building no house was deemed secure from wandering spirits on St. John's Eve, unless the golden flowers, shining leaves, and crimson shoots of the Great St. John's root (Hypericum calycinum) were found close by.

From the low arched doorway of the east front, the only bit of the ancient fourteenthcentury manor house that remains visible, a broad straight walk leads through a gateway covered with Roses and the handsome double pink flowering Bramble, into a delicious pleasaunce; and so, between its lawns to another graceful wrought-iron gate in a stone and brick gateway, opening into the park close to the Lime avenue and the cricket ground.

But if Summer is enchanting at Bramshill when the Lime avenue is in flower, and the 
fine-leaved Heath spreads a crimson carpet over the ground beyond, and the blue distance shimmers in the hot sunshine, what of Spring? Spring at Bramshill is an enchantment when the Horse Chestnut spires-earlier here than anywhere else for miles round-show white against the mellow brick of the noble old house. When the May trees in the dip beyond the cricket ground are white as snow, among the tender pinks and browns and greens of young leafage on Oak and Birch, Lime and Spanish Chestnut, and the ancient Crab trees and wild Cherries are in blossom; when the little brown turtle-doves, intent on nests and nestlings, coo and flutter through the Fir forest, whose young shoots show glaucous green at the point of every bough; or earlier still, when, down the steep hillside beyond the woodyard, we come upon

$$
\text { "A host of golden Daffodils," }
$$

covering an acre's space, fringed round with pale Primroses below the lofty trees. Is not Spring after all the most perfect moment of the year?

And Autumn? When the long gallery and the north front are veiled in crimson and flame 
of Virginia Creeper; and the Beeches are golden and the Oaks copper against the Fir trees; and the Bracken turns every shade from palest yellow to deepest bronze; and the proud pheasants, who have had things all their own way for months, begin to know the fate for which they were raised, and walk warily when they leave its shelter. Then comes the first Wednesday in November, a date much thought of round here. And the great fore-court on the west front, from the steps up to the house almost to the pepper-box towers, is thronged by the whole countryside and bright with red coats, as the hounds meet on the green turf and then stream away through the glades of the park, the low Autumn sun glancing in the frosty air through the shafts of the Fir trees upon red coats and moving horses, and the twinkling tails of eager hounds as they press through the deep Heather.

But Bramshill was once the scene of a more famous and fateful hunting nigh upon three hundred years ago, than has ever befallen with the foxhounds; when King James, and my collateral ancestor, Robert Abbot, Archbishop 


\section{BRAMSHILL}

of Canterbury, were guests of Lord Zouch in 1622. Much against his will, at the command of the King his master, the Archbishop went a-hunting deer in the park. And his arrow, glancing from a tree-the great Oak that stands on the slope beyond the Lime avenue-struck one of the keepers and killed him on the spot. The Archbishop was suspended for a year; and it is said he never smiled again, which one can well believe from the fine portrait by Vandyke, which we possess - the original of that at Lambeth Palace. In a letter written by my father on his arrival at Eversley as curate, in I 842 , he says :-

"I went the other day to Bramshill Park. And there I saw the very tree where an ancestor of mine, Archbishop Abbot, in James First's time, shot the keeper by accident! I sat under the tree, and it all seemed to me like a present reality. I could fancy the noble old man, very different then from his picture as it hangs in the dining-room at Chelsea. I could fancy the deer sweeping by, and the rattle of the cross-bow, and the white splinters sparkling 


\section{EVERSLEY GARDENS}

off the fated tree as the bolt glanced and turned -and then the death shriek, and the stagger, and the heavy fall of the stalwart foresterand the bow dropping from the old man's hands, and the blood sinking to his heart in one chilling rush, and his glorious features collapsing into that look of changeless and rigid sorrow, which haunted me in the portrait upon the wall from childhood. . . . It is strange that this is almost the only portrait saved in the wreck of our family. As I sat under the tree there seemed to be a solemn and remorseful moan in the long branches, mixed with the airy whisper of the lighter leaves that told of present as well as past."

In those charming forest sketches, "Sous Bois," André Theuriet truly says, "On redevient sauvage à l'odeur des bois." And to those who are forest-born and forest-bred there is no nostalgia so poignant as absence from a forest land, no enchantment so great as the " return of the native" and the first breath of the wild woods. To those whose happy fate it has been to live from childhood in such a 
forest land as this corner of the north of Hampshire, Winter elsewhere seems interminable and well-nigh intolerable. For here, what my father so truly called his "Winter Garden" is always about one; and amid the green of Fir trees and Hollies, Furze and Heather, the Winter slips by almost unperceived. I never realised what this meant in one's life until I spent twelve years in the Midlands. And the great rank grass pastures, heavy fallows, and superb Elms, bare for close upon eight months in the year-for I have seen the leaves that came out in May stripped by the first of October-turned Winter into a season of unimagined desolation. But here in his "Winter Garden," as my father wrote, "Enough for me is one purple birch; the bright hollies round its stem sparkling with scarlet beads; the furze-patch, rich with its lacework of interwoven light and shade, tipped here and there with a golden bud; the deep soft heather carpet, which invites you to lie down and dream for hours; and behind all the wall of red fir stems, and the dark fir roof with its jagged edges. ... Endless vistas of smooth red green-veined 
shafts holding up the warm dark roof, lessening away into endless gloom, paved with rich brown fir-needle-a carpet at which Nature has been at work for forty years."

Even on gloomy and stormy days the park has its own strange charm, as one walks up the dusky Fir avenue on the soft Fir-needles glistening with rain. A murmur fills the air above as of sea-waves breaking on a sandy shore. It is the wet south-west wind soughing overhead and lashing the writhing branches, while all is calm below. One thinks of the German fairy tales of one's childhood, and half expects to meet the old woman who led Hansel and Grethel captive, and to catch a glimpse of her house with its gingerbread roof and windows of barley-sugar. Anything might appear in so eerie and moving an atmosphere of strange sounds and dimly-seen shapes. But at most we may chance upon a russet-coated roe deer, a startled rabbit, or the great green woodpecker, who inhabits the same hole in a big Fir tree from which my brother and I tried, and tried in vain, to extract one of his remote ancestors. 
I remember once taking a well-known musician who was staying with us at the Rectory, through those Fir woods on just such a dark afternoon, while the wind was making soft music above us. He was silent; and I was disappointed, for I had fancied the new country would be a delight and excite his imagination. But when we reached home he sat down to the piano in the dark, and played on and on as if he was pouring out his whole soul in a flood of melody; and when, after an hour of marvellous improvisation, he stopped and said to us, "I couldn't help it: I had to reel off all that I have been seeing or hearing this afternoon," I was well content; for nothing had been thrown away on our friend, and if he could not talk about it he could do something better.

And thus I come back to my first question -and verily it is one I cannot answer. I cannot tell, I cannot choose, which of the four seasons is the most beautiful in Bramshill. For let the weather be good. or bad, let the days be long or short, Bramshill remains full of enchantment to one who has known and loved it from childhood. 


\section{CHAPTER XIV}

THE RECTORY GARDEN AND THE MOUNT

In piam memoriam.

A ruined garden. Is there a sadder sight to eyes that have known it in its beauty, to hearts that have loved it in its happier days? Once a place of delight, gay with flowers and the voices of children, cared for and tended by skilful hands. How grievous to find it a mere wilderness, whose

"Hedges, even pleach'd

Like prisoners wildly overgrown with hair, Put forth disorder'd twigs."

The Strawberry bed is a tangled mat of ground-elder; the Raspberries a thicket of barren, attenuated canes. A Cherry tree after long years of neglect has thrown up a forest of suckers, fast growing into sturdy saplings. The Apple trees, once laden 
with rosy fruit, are gnarled, distorted, and smothered in moss and lichen. Against the wall, if the fruit trees are not dead, they have grown wild for want of pruning, or have broken away from the nails that upheld them. Nettles a yard high, flourish and spread where once grew a bountiful supply of choice vegetables. The paths between what used to be borders bright with crimson Pœonies, Damask Roses, or the white spires of Our Lady's Lilies, have disappeared under a carpet of evil weeds. The shrubberies are groves of half-dead Laurel and gloomy Yew. And the well-kept lawns, where philosophers, divines, poets, and men of action gathered under the giant Fir trees to discuss the burning questions of the 'fifties and 'sixties, are given over to mole-hills and ants'-nests, while rat-holes and rabbit-runs testify yet further to the general ruin. This is no fancy picture. For such was the garden of the Rectory, the beloved home of our childhood, when I first entered it six years ago, and found it a wilderness. 


\section{EVERSLEY GARDENS}

Happily, however, this is now a thing of the past. For with infinite care and labour, it has been gradually restored by kind hands to something of its first state of order and beauty; though the long years of neglect have inevitably left their mark, and destroyed much that one fain would still find there.

When my father settled at Eversley Rectory in I 844, most of the garden consisted in a line of fish ponds, running from those in the glebe field, past the house, and joining the large pond belonging to the Church Farm, behind the church. He at once became his own engineer and gardener. The ponds, except three in the glebe field which in course of time were stocked with trout, were drained. What had been a wretched chicken-yard outside the brick-floored room which my father took for his study, was laid down in turf, with a wide border on each side; and the wall between the house and stables on the western side, was soon a mass of creeping Roses, scarlet Honeysuckle, and Virginia Creeper. This became 
" The Study Garden," up and down which my father paced bare-headed, composing sermon or novel, lecture or poem; for he never indulged in "rough copy," every sentence being thought out first, and then written or dictated straight off with hardly a correction.

On the sloping lawn between the house and the road, stood, and still stand, the three giant Fir trees planted at the same time that James I., who was then building Bramshill House, planted the Scotch Firs in the park and the isolated clumps on Hartford-bridge Flats and Elvetham Mounts. Though much broken by gales and snow, as well as by neglect, they are still the pride of the place; the present Rector of Eversley having with great skill chained and braced them up to prevent further destruction. A fine Acacia, and twin Arbor-Vitæ thirty feet high, completed the trees on the lawn in later years. But when we were small children another pair, an ArborVitæ and a Birch, stood in the very centre of the lawn. They were blown down in the famous Royal Charter gale, to the great benefit 
of the house, for they darkened the windows, and impeded the view of the great glebe field, the Mount, and the fringe of Firs against the sky on the moor above. And no one lamented them save my brother, who, being an active climber, found them an excellent asylum from his tutor, or from Turk and Brenda, the alarming Scotch deerhounds, whose advent somewhat detracted from the joy with which we welcomed relations, who drove over in state for the day from Maidenhead and Taplow.

Masses of shrubs were planted to keep out the cold draughts of air, which even on Summer evenings streamed down from the large bogs a quarter of a mile away. Plane trees, which threatened in every high gale to fall upon the south end of the house, were cut down. And our sleep in May was thenceforth undisturbed by a nightingale, who shouted so loud from one close to my window, that I remember once hurling at the "poor bird, as all forlorn" he sang the night through, anything that came handy, from coals to boots. 


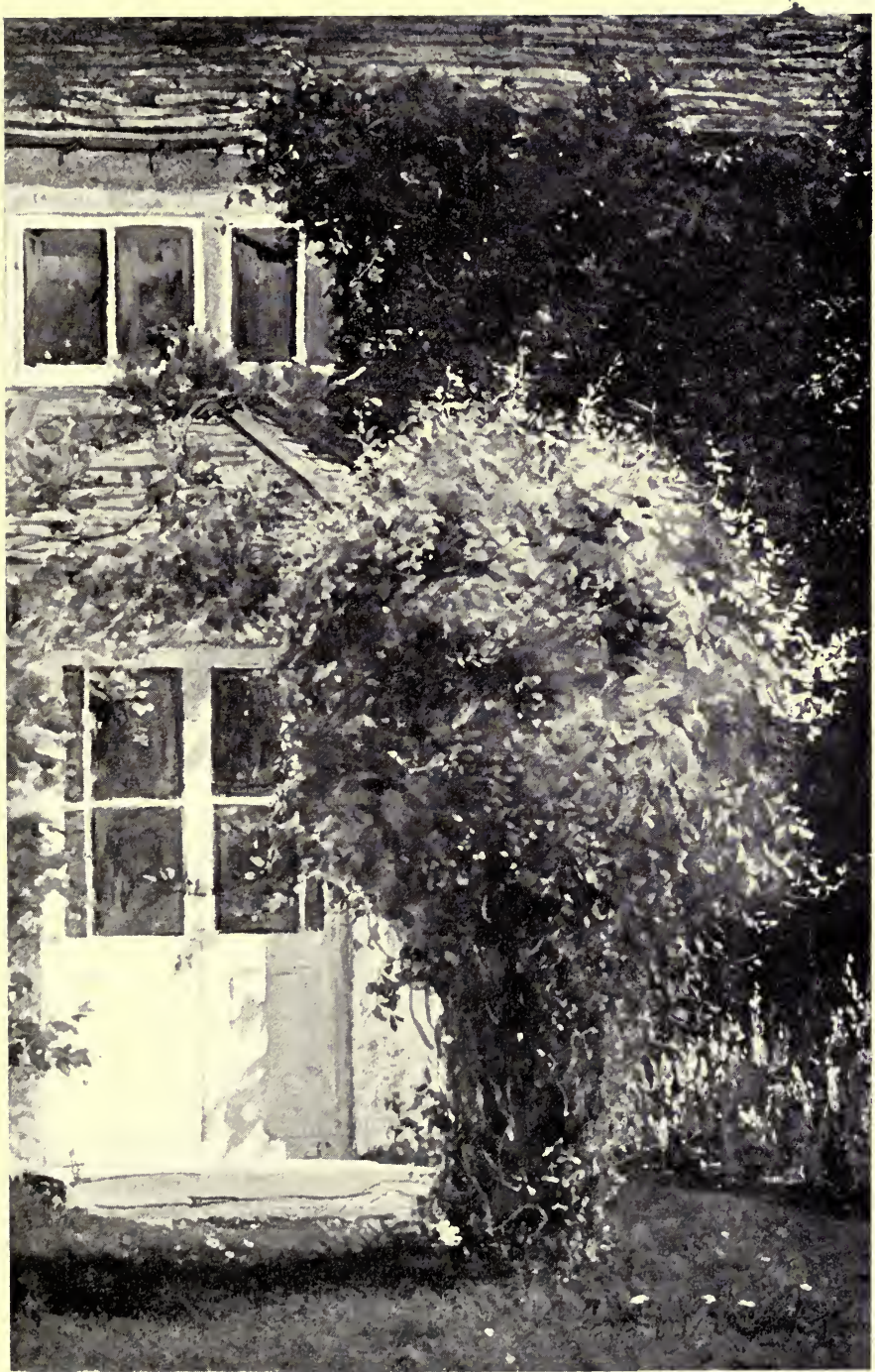

From a Sketch by Dollman

Japanese IONeysuckle in the Study Garden. I 875 p. 258 

Against the south wall of the house which looks on the dear "Study Garden," a Magnolia, $M$. grandiflora, was trained, filling the air and all the rooms with its fragrance. It still lives; and has, I hope, lately taken a new lease of life: but having for some years been used by rats as a ladder to the window of an upper room, it was in a sad state six years ago; and only the utmost care has saved it from utter destruction. Lonicera flexuosa, Clematis montana, Wistaria, Gloire de Dijon and Ayrshire Roses, with a fine variegated Ivy, hid the wall in a veil of verdure and sweetness. The great treasure of the Study Garden was-alas! it is no morean immense plant of the Japanese Honeysuckle, L. reticulata aurea, trained over an iron umbrella in front of the study window. This was given to my father by Mr. Standish, when only a tiny pot plant with six leaves, a year and more before it was distributed to the public. Well do I remember his delight at bringing it home after a visit to Sir James Clark at Bagshot Park. And carefully the 


\section{EVERSLEY GARDENS}

little plant was nursed and well it throve; being covered every Summer with sweet flowers, and with bright purple berries for Autumn decoration; while its descendants, from cuttings, abound in the parish still.

Next to the Golden Honeysuckle the pride of the Study Garden lay in its Yellow Persian Briar-roses. These, which came originally from the great plant in the corner of the troco ground at Bramshill, grew very freely; and in June the walls of the house and garden were ablaze with the vivid golden blossoms, the rooms being always decorated for two or three weeks with dishes of the yellow Roses, mixed with darkest purple Pansies on a ground of wild Fern. There was no need in those days to buy a bunch of "French Fern" from the nearest florist; for Asplenium Adiantum nigrum then grew plentifully up the lane beyond the Rectory, though it has now nearly disappeared.

Only a few plants were kept for bedding in a little pit which my father and our faithful man, George Chaplin-whom he took as a lad 


\section{THE RECTORY GARDEN 26I}

from the plough-tail and trained himselfconstructed together. And owing to light soil, and early and late frosts which were peculiarly destructive owing to the low-lying situation of the Rectory, none but the hardiest and most common plants could be grown out of doors. Yet despite these drawbacks the borders were always as bright as those in more favoured spots, filled with such plants as Phloxes, Delphiniums, Alyssums, Saxifrages, Pinks, Pansies, and, above all, Roses and Carnations which grew in profusion without the least trouble. And perhaps the gayest moment of the Rectory garden, was when every border round the house was edged with a thick band of blue Forget-me-not outside another of pink Silene, so that the old mellow brick walls rose from out of a lovely setting of pale blue and pink. One bay on the front of the house was well covered with Pyracantha, in which a pair of white-throats built for many years undisturbed, just under my mother's window. The farther bay, up to I 860-I, was quite covered by a magnificent plant of the Noisette Rose, Faune 
Desprez: but the severe cold of that Winter killed it to our lasting sorrow, for it had been our pride and glory, and its place was taken by hardier creepers. Over the glass porch of the front door Clematis Jackmanni, the white cluster Rose Félicité Perpétuée, and Pyrus Faponica were woven in lovely confusion. The Pyrus still exists; and its scarlet flowers still go, as in old days, to help to decorate the church at Easter.

Rhododendrons loved the peat that could be had for the carting from the bogs just beyond the Mount. They grew luxuriantly; and the neighbours always came to see the Rector's garden when the big beds on either side of the front gate were in blossom. At the end of the Study Garden, between these beds and the stable-yard, was a little Rose garden, a choice and sheltered retreat, with a pink Thorn in one corner near the gate, and pillar Roses at the back of the border. And in one of the big bushes that shut it off from the drive a blackcap built year after year, to my father's extreme delight, so tame that we could watch his little throat as the enchanting notes of his song rose 
THE RECTORY GARDEN 263

in the air. I specially remember among those pillar Roses in my childhood, Chenédolé, Fulgens, Gloire des Rosomanes, Fellemberg, Aimée Vibert, Coupe d'Hébé, Crimson Madame Desprez, and Maria Leonida. In an old copy of Rivers' "Rose Guide" of 1844 , the year my parents settled at Eversley, I find a list in my father's writing appended to the printed list he had marked, decorated of course with an outline head in pencil-for blotting paper, books, and slates were covered with such sketches as he paused for a moment. The list is apparently a suggestion for the beginning of a Rose garden. I wonder how'many of these varieties would it be possible to find nowadays? In later years many dwarf Roses were added to that early list, and great was my father's delight over Victor Verdier, which was one of a dozen from Walters' of Exeter, which our dear parlour-maid, Susan Blackmore, brought him on her return from a holiday in her native Devon. She lived in our family for forty years, ruling us all with dignified and severe devotion, and died in my sister's service as a woman of over seventy. 
We children each had our own little plots in the back garden; and, not wholly content with my first little bed close to the great Fir tree near the back-yard, with its Damask Rose bush, white Pinks, Polyanthus, and two precious plants of blue and pink Hepaticas, I managed to get an extra portion containing a fine standard of Coupe d'Hébé, which I had long desired. But after hours spent in sowing and raking, great was the fall of my pride when George Chaplin remarked as he passed, "Why, Miss Rose, have the hens been a-scratching here?" The back garden was a delightful place; and the long straight walk that runs from the stable-yard to the old Heath house my father built us for a play-place, was always brilliant in Spring and Summer with a wellfilled flower border on either hand. The old Damask Roses simply ran riot in those borders, with common crimson Pœonies, white Pinks, green cushions of Saxifrage hypnoides, clumps of the great pink $S$. crassifolia, Polyanthus and Wallflowers, Moss and Cabbage Roses, and Violets everywhere. But those said Violets 


\section{THE RECTORY GARDEN 265}

were a source of trouble to us; for whether we planted the white or the blue, in a couple of years they had turned to a dull reddish maroon, and though they "would smell as sweet" they were far less lovely; while just over the hedge, in the bit of field my father took in as a "spade farm," the Violets remained blue, and in the churchyard were always purest white.

It is no wonder that when my father went to Eversley in 1842 , spending the first six weeks of his life as curate of Eversley in the Rectory house, he was charmed with the view from the windows of the lawn and the glebe field. On July 14, eighteen months before his marriage, he sent my mother a slight pencil sketch, saying, "I am no drawer of trees, but the view is beautiful. The ground slopes upwards from the windows to a sunk fence and road, without banks or hedges, and then rises in the furze hill in the drawing, which hill is beautiful in light and shade, and colour. . . Behind the acacia on the lawn you get' the first glimpse 
of the fir forests and moors, of which fivesixths of my parish consist. Those delicious self-sown firs!"

And when, two years later, he returned to Eversley as its rector, the "furze hill," known as "The Mount," and crowned with an ancient pollard Oak, became in course of time one of the spots he best loved. It is a little bit of primæval forest, covered with fine Oaks and Hollies, Beeches, wild Cherries, and Crab trees-the ground below white in Spring-time with Wood-anemones, blue with wild Hyacinths, and jewelled with Primroses and Meadow Orchis; while on the open slope beneath the great Oak, the wild Thyme in Summer grows in thick, fragrant cushions. The old hollow Oak, which according to the best authorities must have been a lusty young tree at the time of the Norman Conquest, became a favourite resort of his children; for by means of two or three stout bars across the rent in its side we could climb into its enormous branches, and there read, or attempt to learn our lessons. But it was 
not a place for very concentrated study, as birds and beetles, squirrels and butterflies, were most engaging and distracting neighbours. At the farther end of the Mount in the 'sixties, my father built with his own hands a delightful play-place for my sister and youngest brother-the thatched hut where their toys, and books, and tea-things were kept; and on an outdoor fireplace of four bricks the kettle was boiled every day for their tea. At the same time, when all England had just succumbed to the game of croquet, he had a charming croquet-ground cleared and levelled for me near by, shaded by fine Oaks and Hollies. And thus the Mount gradually became our open-air drawingroom and second garden, to which all resorted in the hot weather.

When the Enclosure Act was passed, a large amount of moorland beyond the Mount was allotted to the glebe. My father disapproved of the measure as deeply as did Shakespeare of "the enclosing of Welcombe," and opposed it by all means in his power. 
But when once it was a fait accompli, he tried to make the best of it by planting and beautifying a strip of three or four hundred yards, lying along the high-road, and sloping down west to the great glebe field. From the Hut he made a level walk with good Rhododendrons on either side; while as a screen from the road he planted with his own hands a row of Cupressus Lawsoniana on the bank. These have grown into a wall of rich dark green, five-and-twenty feet high; while the Rhododendrons within, and the many others planted on the Mount itself, have become huge spreading bushes, a beautiful sight in June when they are in full blossom.

An old sand-pit close to the Hut was overgrown with gigantic Brambles, a thorny waste; and these my father set to work to root out-no easy task, as all know who have tried to grub old Brambles. But with a strong clawing-fork, made by the village blacksmith according to his instructions, he would tear up their mighty roots whenever 
he had a spare half-hour, and conquered them at last. One day while he was thus employed, Dr. Benson, then Headmaster of Wellington College, found his way up to the Mount, with Dr. Lightfoot, who was staying with him. Both were at once impressed for work on the Bramble roots; and the sight of that learned and great divine, afterwards Bishop of Durham, toiling away in his shirtsleeves as earnestly as any day-labourer working for his bread, was a sight never to be forgotten. In the extremely simple life we led in our childhood, the advent of a white-tilted cart filled with flowers from some neighbouring town, always caused intense excitement. And to this day neither my sister nor I can resist buying from one that stops at our respective houses during the Summer months, in memory of the long-ago days when its prototype used to draw up at the Rectory gate. Every available penny was scraped together to buy a Geranium, a Heliotrope, or a Fuchsia. And the finest prize Pelargonium of to-day could never give the delight a rather 
small-flowered purple one from those tilted carts gave its proud possessor. But if we could afford a large-flowered pink one with crimsonblack blotches, like those we almost worshipped in the hall at Ray Lodge, then indeed our cup was full to overflowing; for they were much dearer than the purple one, and seldom to be acquired.

But an even greater event was an expedition with our parents to "Shilling's Nursery"the modest forerunner of the present grandson's establishment-near Hartley Row, there to choose a plant or shrub from the open ground. From that enchanted spot came the luscious pink Daphne cneorum and the beloved "Nutmeg" plant (Calycanthus Floridus) of the Study Garden; the Kalmia, or, as we always called it, I know not why, the "Pincushion flower," that flourished in such beauty among the Rhododendrons by the front gate; with Heaths too-the early carnea, the white Mediterranea, and the great purple Irish Heath (Menziesia). From thence came my pink and blue Hepaticas, and a dozen other precious 

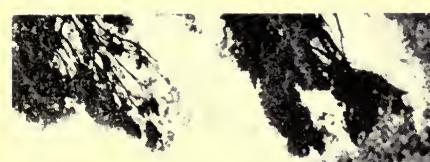

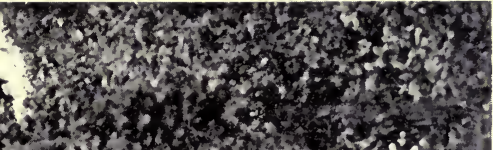

인

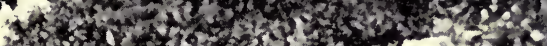

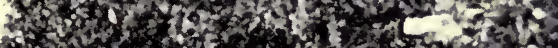

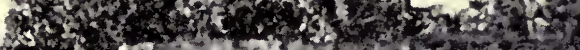
sis?

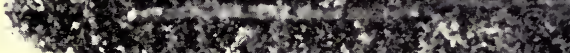

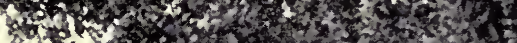

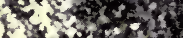

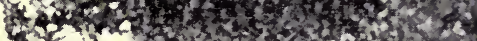
at: , .

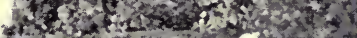

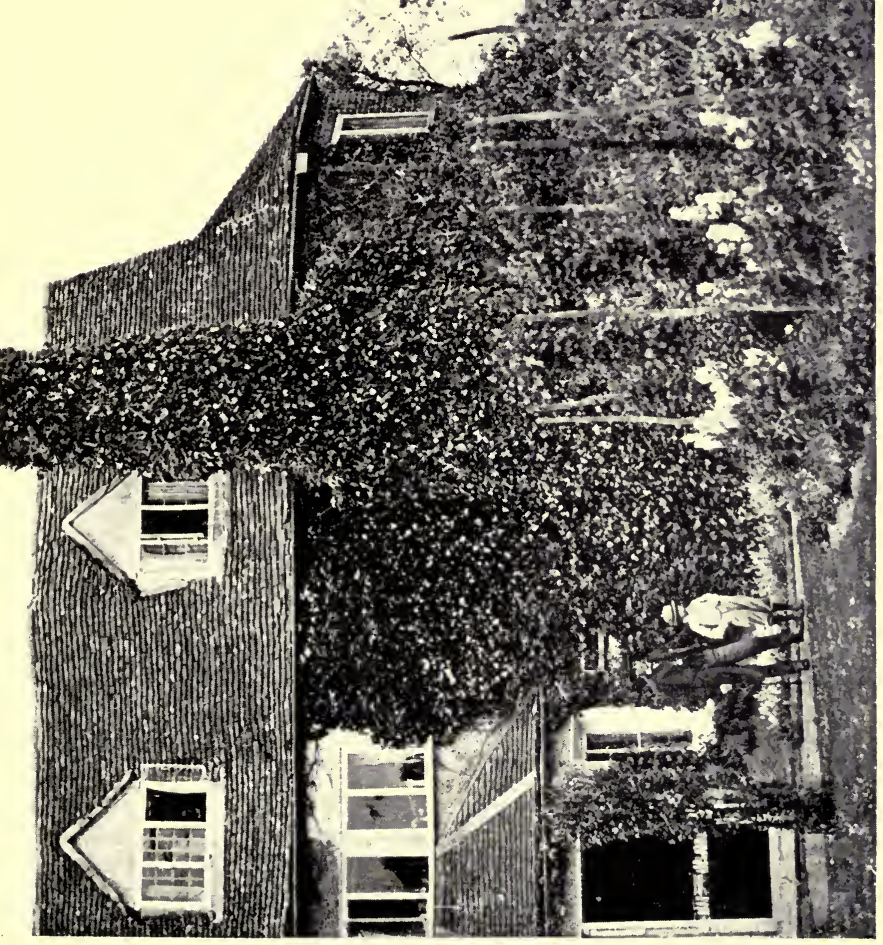



possessions, in our eyes of quite infinite value.

Then homeward again by Hartford Bridge and the old "White Lion" posting inn, with its memories of George III., and the Prince Regent, and the forty coaches each way that stopped to change horses on their journey between London and Southampton, and the terrible end of the old ostler, who cut his throat on the day the London and SouthWestern Railway was opened. Then up the long, beautiful Star Hill, where the flowers in the cottage gardens are always a week earlier than anywhere else in the neighbourhood; and over the great heather-clad stretches of Hartford-bridge Flats, and down Brick House Hill past the Mount to the Rectory, to recount our adventures and display our treasures.

An ancient Yew tree-a real "Bow Yew," carpeted beneath with small double purple Periwinkles-and a slight hedge of Laburnum, Hollies, Lilac, and Syringa, divided the 


\section{2

Rectory garden from the churchyard. And here again my father endeavoured to make the best of that which he found under his hand. The plain red brick of the churchonce a cell of St. Peter's, Westminster, and rebuilt in its present form in the days of "Good Queen Anne"-was gradually clothed with Roses, Ivy, Cotoneaster, Pyracantha, Honeysuckle, \&c. And in order that his parishioners should look on beautiful objects as they assembled in the churchyard for their Sunday gossip before service, the old part of the churchyard was planted with choice trees and flowering shrubs-Juniper, Cypress, Irish Yew, Berberis, Rhododendron, Acer Negundo, and Sweet-briar; and the grass was dotted with Crocuses where it was not already carpeted with white Violets. These shrubs and trees have now grown so large that they have to be carefully clipped to keep them within bounds. And the largest of all is a fine young Wellingtonia, a seedling from a cone my father picked up in the Mariposa Grove in May 1874. After his death, in 1875, the 
cone split open, and I potted two of the seeds which fell out. They grew so well, that two years later I sent them to our old schoolmaster and clerk, Frederick Marshall. One he planted in the churchyard, the other on the slope of the Mount; and my amazement was great when I returned to Eversley, to find the tiny seedlings had turned in the space of twenty years into forest trees.

But of all spots in the Rectory garden, memories crowd most thickly about the three giant Fir trees. Memories of gatherings round the great South American hammock, that hung in Winter across the study and in Summer from the huge horizontal limb of the outer Fir tree. Gatherings when talk of "high emprize" between men of letters, divines and scholars, famous soldiers and sailors, statesmen and men of science, flowed freely and eagerly; broken by some flash of humour, some turn of thought as tender as it was unexpected, from their host, touching the dark places with light, and drawing the best from each speaker. There was no lack of whole-hearted laughter, of gentle gaiety, in 


\section{4 EVERSLEY GARDENS}

those symposiums, when the talk ranged up and down the universe, from the beetle that crawled in the grass to the last bill before Parliament, from man's ways and works to things Divine.

Strangely diversified were the visitors who found their way to the Rectory in those days. One Sunday, I seem to see a tired compositor from a great London printing-house, who had come down to talk over the grievances of his fellow-workmen. Another Sunday, that Royal personage whom my father loved with such devoted loyalty, sitting on his fine brown charger at the door, before riding back to the camp of his gallant roth Hussars in Bramshill Park. Yet again, gentle Queen Emma of the Sandwich Islands, coming to stay with the man whose books she and her husband had read in their far-off Pacific kingdom, and to see what English boys' cricket was like at Wellington College. Or Alfred Tennyson -as he then was-smoking pipes in the study, when he came to see whether the beautiful old Brick House Farm, close to the Mount, would be a fit place to settle in when he won his lovely 
bride. But one of my earliest and most vivid childish recollections, is of a walk with that tiny and dainty lady, Frederika Bremer, whose greatest wish on her arrival at the Rectory was to see a Furze bush, such as the one before which her great countryman, Linnæus, had fallen on his knees and given thanks. My father took her up to the moor on the road to Bramshill; and the big Furze bush in the Heather went by her name, till the terrible heath-fires of 187 I blotted it out.

But more precious far are memories of the quiet home life. Hot days when my father would tempt his favourite pair of natterjacks from their hole in the lawn beyond the Acacia tree, and walk up and down admiring the colours on their backs, while the little creatures sat contentedly in his hand; or when he would persuade the half-tame slow-worm to come out of his nest in the steep, Thymegrown bank of the sunk fence. Memories of warm Summer evenings, when, in the soft dusk, German part songs and English glees would float up in the still air beneath the huge canopy of the Fir boughs; and my father would 
ask for one and another of his favourites, or bid the singers listen to the chirring of the nightjar, or hold up a hand to point out the stealthy flight of a white barn-owl.

The natterjacks have gone. So has the slowworm. Black and tabby cats have taken the place of the white ones that peopled the stables.

But in the garden under the Fir trees, a little square stone still marks the grave of the beloved Dandy Dinmont, my father's devoted companion and friend; the inscription he wrote still fresh upon it:

“Dandy, I849-6r. Fideli Fideles."

While but a few yards away, close to the garden he made, in the churchyard he planted, shaded by the Fir trees he loved-a living presence still to those who knew him, helper and comforter still to thousands who never saw his face, faithful to the end to his Church, to his ideals, to his fellow-man, Dandy's master rests. 


\section{N D E X}

A

Abbot, Archbishop, 248

Abol insecticide, 218

Alstrœmeria psittacina, 103, 108

Anemone Appenina, 236

- fulgens, 43, 236

Annuals, 114-24 half-hardy, 108.

Aphis, remedies for, 218

Apples, 12, 62-3

Aquilegias, III

Arabis, 43, 185

Artists, 19

Ash, 3

Azalea, 69, 86, 235

B

Bacon's Essays, 244-6

Barton Hall, 224

Beacon Hill, 175,242

Benson, Archbishop, 269

Berkshire, 2

Birds in the garden, 20r

- harmful, 213-16 useful, 208-13

Bishop Lightfoot, 269

Blackbird, 206

Blackcap, 262

Blackwater, 25, 179

Bluebells, 46, 67

Border of Friendship, 105-8

Bramshill, 20, 25, 237-53

Bulbs, grounding for, 45

- in peat fibre, $5 \mathrm{I}-7$ school children's competition, $57-8$

Bullfinch, 213
C

California, 85-6, 272

Calycanthus, Floridus, 86, 270

Campanulas, $\mathrm{Ir}^{-14}$

Carnations, Clove, 107, 109

- Marguerite, rog

in vases, 193

Caterpillars, 216

Ceanothus, 85

Chaplin, George, 15, 91, 260

Cherry, wild, 40, 63

- single and double, 64-5, 67

Choisya ternata, 87

Chrysanthemum, annual, II6

- border, 199, 201, 230

Churchyard, Eversley, 272

Colour in winter, 88

Conscience, points of, 44

Cope family, the, 240

Crab, 63, 226

Crown Imperials, 42

\section{D}

Daffodils, 49-5I, 180

- Grandee, 47

for decoration, I9I-2

Damson, I2

Dandy, 276

Delphinium, ro7 sowing, III

E

Elvetham, 25, 77, 240

Erythrina Christagalli, 178

Escape, a narrow, 86

Eversley, forest of, 25 
Eversley, frosts at, 25-6 soil of, 24

\section{F}

Fashion in flowers, 137-9

Fern-owl. See Goatsucker or Nightjar

Finchampstead Ridges, 180, 229

Fir Avenue, 241, 252

Fir Trees, Scotch, 175, $24 \mathrm{I}$

- at Rectory, 257, 273

Florence, 20

Flower-carts, 269-70

Flowers, for decoration, 188

- in Autumn, I97-201

- vases for, $189-92$

Forget-me-not, 26I

Fruit trees, II

Fuchsias, 42, 175, 178, 180

\section{G}

Garden of Delight, 46, 59, 66, 99 , 173

- in bulb time, I8o

- flowering shrubs in, $x 82$

- Daffodils in, 183

- Lent Lilies in, 185

- the Autumn, 220

- a ruined, 254-5

- personal note in, IOI-05

- a Ross-shire, 106

- the Study, 257-60

Gladioli, 236

Goatsucker or Nightjar, 20, 2 II, 276

Godetias, Ir6

Guelder Rose, 60, 95, 202, 228

\section{$\mathrm{H}$}

Hampshire, 2

local names, 3, 208

Haricots-verts, 2I

Hartford Bridge, 27 I

Flats, 6, 175, $27 \mathrm{I}$

Hawthorn, 65-6

Heath fires, 24I, 275

Heather, 6, 24I, 243, 25I
Herbaceous border, I 10

Holland House, $142-3$

Holly, 24, 84, 25 I

Honeysuckle, Japanese, 259-60

Hyacinth, Grape, 46, 184, 186

Roman, 54-5

Hydrangea paniculata, 99, 176, 23I, 235

- pink, 180

I

Iris, yellow, 179

- Kæmpferi, 186

J

James I., at Bramshill, 240, 257

Jay, 215

Jonquil, Queen Anne's, 43

Keys, 2

K

- tea-rose beds at, I $47-48$

L

Laburnum, 95

Larkspur, Sutton's Rosy-Scarlet, II7, 250

Laurel, 80-I

Lilacs, $9 \mathrm{I}-4$

- list of best, 93

- pruning, 92

Lilies, St. Bruno, ro6

- Lent, 4I, 185, 247

Our Lady's, I05, 255

Water. See Nymphæa

Lilium auratum, 236

Limes, 13, 20

Loam, 25, 28

Lobelia Cardinalis, 99, 168, 23I-2

Local names, 3, 208

Lupin, I ro

\section{M}

Magnolia, 60, 96

- conspicua, in Paris, 97 grandiflora at Savannah, 97 stellata, 180

Manure, 27 
Maples, American, 89-9o

Japanese, 89, 227

Marrow-bed, 2I

Medlar, 226

Michaelmas Daisies, 233-4

Mount, the, 266-9

Munshi Mahmud, 82

N

Natterjack, 275

Nemesia strumosa Suttoni, I 18

Newbury, 242

Nicotiana affinis, 119

Sanderæ, 100, II 8, 176

Nightingale, $25^{8}$

Nymphæa alba, 177

scutifolia, $177-8$

\section{$\mathrm{O}$}

Orchard, II

$\mathrm{P}$

Partridge, 2II

Peach, 65, 82

Pear, 12, 225

Pœonies, I12, I69

Pentstemon, 23r

Perennials, staking and tying, II2

Phlox, 112

Plants, food for, 23

Planting. 27-3I

Ploughing, 19

Plums, 12, 61

Polyanthus, 44, I80

Poplar, balsam, 15, 229

- Lombardy, 14-16

Poppy, Oriental, r Io Shirley, II 5

Pots, sunk in turf, $176,178,182$

Primula rosea, 185

Pruning, 31

Prunus Pissardii, 6r, 187, 221

— forced in water, 196

$\mathrm{R}$

Rectory, The, back garden, 264 view from, 265
Rectory, visitors at, 274-5

Renaissance, English, 237-9

Rhododendrons, $4,9,83,174$

— at Bagshot, 69-77

- soil for, 28

- at Elvetham, 77

- at the Rectory, 262

- on the Mount, 268

- early, 75

- late, 76

- list of best, 74-5

- life history of, 77-8

Rhus cotinus, 90, 224

Road-scrapings. 27

Robin, 204

Rocky Mountains, III, 23I

Rose beds, $8,28,1_{47}-8,170$

- planting, 27-3r

pruning, 3I-39

- Gloire de Dijon, 127

- Fortune's Yellow, 151-2

- Fortune's Yellow pruning,

$\mathrm{I}_{52}$

Jaune Desprez, 150, 26I

Rêve d'Or, 153

Wichuraiana, I59, 164-5, 188

Roses, Caroline Testout, at

Holland House, 142-3

China, 39, I6I

climbing, II, 149, 150-2,

243, 259, 26r

damask, 39

in " Expert's" garden, I70-

172

on fence, II

for exhibition, 33

Crimson Rambler and Reine

Olga, 169

- half standards, $\mathbf{1 7}$ I

- hybrid perpetuals, 35, 166

- hybrid tea, $\mathrm{x}_{40-47}$

- semi-double, 146

- single, $\mathrm{x} 47$ at Louvre, 32-3

moss, 39

noiset te, $3^{8}$

pillar at Rectory, 262-3

Penzance Sweetbriars, 155-7

polyantha, $\mathbf{r} 6 \mathbf{x}$ 
Roses, Persian briars at Bramshill, 244

- Persian briars at Rectory, 260

- Summer, r6r-5

tea, $37,125-36$

for Autumn, 129

chief raisers, 128

- some of the best, $130-36$

- in vases, 193 rambler, 38

Rubbish heap, value of, 22

\section{$S$}

School children's competition, 57 Scilla Sibirica, 55, $185^{-6}$

Scotch Firs, I75, 241

Shilling's Nursery, 270

Shrike, red-backed, 2 I2

Shrubbery, the, 79

Soil, 6-9

- tilling, 19

- of Eversley, 24

Sparrow, 2 I 5

Spiræa, 6o, 97-9

prunifolia, 222 opulifolia aurea, 222

Spring flowers, 4I

St. John's Wort, 246

Stone-chat, 2, 2 ro

Straight lines, 5

Study Garden, the, 257-60

Sumach, 224

Venetian, 90

Sweet Peas, Ir9-124

- in water, $\mathbf{1 9 3 - 4}$

Syringa, 94
Tachbrook, 80, 102

Thrush, 205

Tits, 209

Tomtit, 43

Trees, 13 flowering, 89 fruit, in gardens, 225

Trillium, 46

Trinidad, 179

Troco, 243-4

Tulips, 43

- May-flowering, 58-9, 181

Turtle-doves, 247

\section{V}

Virginia Creeper, 223

in Central Park, 224

\section{WV}

Water Lilies, $\mathbf{1 7 7 - 8}$

Wellingtonia, 272

White-throat, 43

Windsor, 172

Forest, 25, 242

" IVinter Garden," 25r-2

Winter in the forest, $250-2$

\section{Y}

Yew at Rectory, 27 1

Yews, clipped, ro4

\section{Z}

Zouch, Lord, 240

Printed by Ballantrne, Hanson \& Co.

Edinburgh \& London 



\section{UNIVERSITY OF CALIFORNIA LIBRARY}

\section{BERKELEY}

Return to desk from which borrowed.

This book is DUE on the last date stamped below.

7 Mar"53VL

R 161953 LU

ERLIBRARY LOAN

IMR 201986

V. OF CMUF. BERK. 



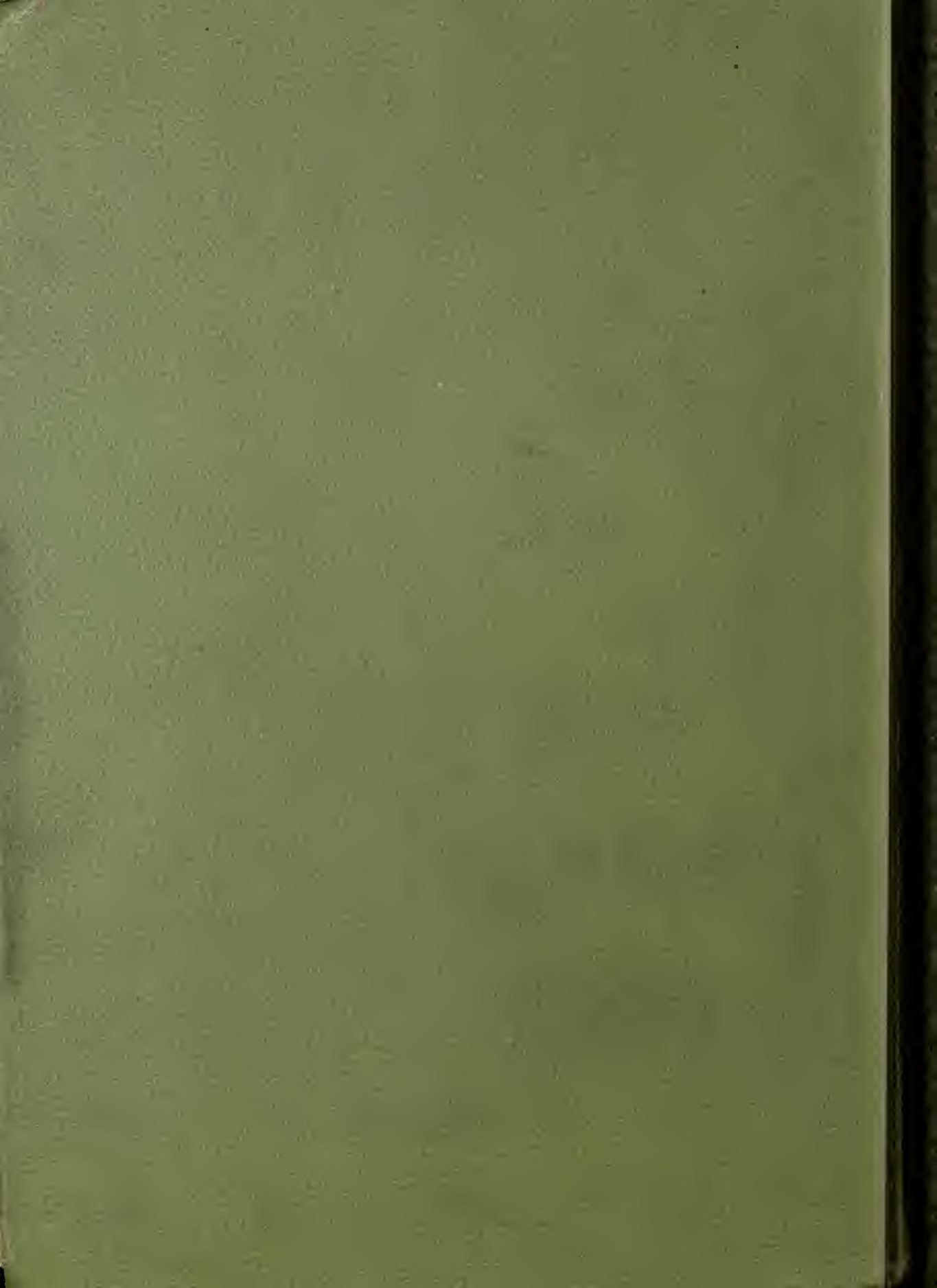

